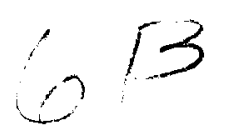

\title{
Eielson Air Force Base Operable Unit 2 and Other Areas Record of Decision
}

R. E. Lewis

R. M. Smith

October 1994

Prepared for the U.S. Department of Energy under Contract DE-AC06-76RLO 1830

Pacific Northwest Laboratory

Operated for the U.S. Department of Energy

by Battelle Memorial Institute 


\title{
DISCLAIMER
}

This report was prepared as an account of work sponsored by an agency of the United States Government. Neither the United States Government nor any agency thereof, nor Battelle Memorial Institute, nor any of their employees, makes any warranty, expressed or implied, or assumes any legal liability or responsibility for the accuracy, completeness, or usefulness of any information, apparatus, product, or process disclosed, or represents that its use would not infringe privately owned rights. Reference herein to any specific commercial product, process, or service by trade name, trademark, manufacturer, or otherwise does not necessarily constitute or impiy its endorsement, recommendation, or favoring by the United States Government or any agency thereof, or Battelle Memorial Institute. The views and opinions of authors expressed herein do not necessarily state or reflect those of the United States Government or any agency thereof.

\author{
PACIFIC NORTHWEST LABORATORY \\ operated by \\ BATTELLE MEMORIAL INSTITUTE \\ for the \\ UNITED STATES DEPARTMENT OF ENERGY \\ under Contract DE-ACO6-76RLO 1830
}

Printed in the United States of America

Available to DOE and DOE contractors from the

Office of Scientific and Technical Information, P.O. Box 62, Oak Ridge, TN 37831; prices available from (615) 576-8401. FTS 626-8401.

Available to the public from the National Technical Information Service, U.S. Department of Commerce, 5285 Port Royal Rd., Springrield, VA 22161. 
PNL-10056

UC-602

\title{
EIELSON AIR FORCE BASE OPERABLE UNIT 2 AND OTHER AREAS RECORD OF DECISION
}

\author{
R. E. Lewis \\ R.M. Smith
}

October 1994

Prepared for the U.S. Department of Energy under Contract DE-AC06-76RL0 1830

Pacific Northwest Laboratory

Richland, Washington 99352 
. 


\title{
Eielson Air Force Base Operable Unit 2 and Other Areas Declaration of the Record of Decision
}

\author{
Site Name and Location \\ Operable Unit 2 \\ Eielson Air Force Base, Alaska
}

\section{Statement of Basis and Purpose}

This decision document presents the selected remedial actions and no action decisions for Operable Unit 2 (OU2) at Eielson Air Force Base (AFB), Alaska, chosen in accordance with the Comprehensive Environmental Response, Compensation, and Liability Act (CERCLA), as amended by the Superfund Amendments and Reauthorization Act (SARA), the May 1991 Federal Facility Agreement entered into by the Air Force, the U.S. Environmental Protection Agency (EPA), and the State of Alaska, and to the extent practicable, the National Contingency Plan. This document also presents the decision that no further action is required for 21 other source areas at Eielson AFB. This decision is based on the administrative record file for this site.

The State of Alaska concurs with the selected remedies and the no action decisions.

\section{Assessment of the Sites in Operable Unit 2 and Other Areas} Operable Unit 2 consists of seven source areas that have been combined because of commonalty in contamination that is mainly caused by leaks and spills of fuels.

The OU2 source areas are

- ST10--E-2 Petroleum, Oil and Lubricant (POL) Storage

- ST11--Fuel Saturated Area

- ST13--E-4 Diesel Fuel Spill

- SS14--E-2 Railroad JP-4 Fuel Spill Area

- ST18--Oil Boiler Fuel Saturated Area

- ST19--JP-4 Fuel Line Spill

- DP26--E-10 Fuel Tank Sludge Burial Site.

Three of the sites (ST11, ST18, and ST19) will receive no further remedial action because they present little risk to human health and the environment. No feasibility study (FS) was conducted for these three sites. However, the groundwater at these sites will continue to be monitored as part of the Sitewide Program to confirm the results of the remedial investigation (RI). Four sites (ST10, SS14, ST13, and DP26) will be remediated.

In addition, 21 areas previously identified as potential sources of contamination will receive no further action because, based on existing information, they do not present an unacceptable risk to human health and the environment. A description of these areas is included in the Phase 1 source evaluation report (SER). Data from these sites were compared to screening criteria (e.g., maximum contaminant levels [MCLs], EPA Region 10 guidance) to evaluate the hazards. If contamination at a site was below the screening level or the affected pathway was incomplete, no further action was required. Source areas that met these requirements are

- LF05--Old Army Landfill 
- LF07--Test Landfill

- FT08--Fire Training Area, Past

- SS12--JP-4 Fuel Spill, Building 2351

- ST15--Multiproduct Fuel Line

- ST16--MOGAS Fuel Line Spill

- ST17--Canol Pipeline Spill

- SD21--Road Oiling--Quarry Road

- SD22--Road Oiling--Industrial Road

- SD23--Road Oiling--Manchu Road

- SD24--Road Oiling--Gravel Haul Road

- DP28--Fly Ash Disposal Site

- DP29--Drum Burial Site

- SS30--Polychlorinated Biphenyls (PCB) Storage Facility

- SS31--PCB Storage Facility

- DP40--Power Plant Sludge Pit

- SS41--Auto Hobby Shop, Past

- SS42--Miscellaneous Storage and Disposal Area

- SS47--Commissary Parking Lot Fuel Spill

- WP60--New Auto Hobby Shop

- SS62 --Garrison Slough.

Actual or threatened releases and exposure of people to hazardous substances from sites ST10, SS14, ST13, and DP26 within OU2, if not addressed by implementing the response action selected in this record of decision (ROD), may present an imminent and substantial endangerment to public health, welfare, or the environment.

\section{Description of the Selected Remedy}

A FS was conducted for ST10, SS14, ST13, and DP26. The sites were paired (ST10 and SS14; ST13 and DP26) and treated jointly in the FS because of their physical proximity and commingled groundwater contamination. Five remedial alternatives were analyzed for each pair of sites. They are

Alternative 1--No Action

Alternative 2--Limited Action

Alternative 3--Bioventing

Alternative 4--Soil Venting/Air Sparging/Passive Skimming at ST10 and SS14

Soil Venting/Air Sparging/Active Skimming/Groundwater Treatment at ST13 and DP26

Alternative 5--Soil Excavation/Groundwater Treatment.

Because of the variable levels and distribution of contamination, slightly different alternatives were evaluated for these two pairs of sites.

Alternative 4 is the selected remedy for ST10, SS14, ST13, and DP26. It addresses the threats posed to human health and the environment by the site by reducing the source of groundwater contamination. This remedy is intended to achieve groundwater cleanup through source removal.

The major components of the selected remedy include

- Install an active skimming system to remove fuel floating atop the groundwater at ST13 and DP26 where the product is sufficiently mobile to be recoverable. 
- Install passive skimming systems to remove fuel floating atop the groundwater and to prevent fuel from seeping into Hardfill Lake at ST10 and SS14 where the product is sufficiently mobile to be recoverable.

- Install a bioventing and soil vapor extraction (SVE) system to remediate soil contamination that poses a threat to groundwater through leaching. This system may include air sparging within the upper part of the groundwater table and the smear zone to volatilize and promote bioremediation of the contaminants. This entire system is also anticipated to reduce fuel floating atop the groundwater.

- Install groundwater extraction and treatment facilities in areas of highest groundwater lead concentrations at ST13 and DP26. The physical/chemical treatment of the groundwater includes precipitation of metals and air stripping of volatile organic compounds.

- Monitor groundwater at ST19, ST10, SS14, ST13, and DP26 to evaluate contaminant levels and migration until remediation levels are achieved.

- Monitor the distal end of the contaminant plume at ST13 and DP26 to evaluate if the plume is expanding. Monitoring will continue for 5 years, at which time the need for further monitoring will be reevaluated. Hydraulically contain the groundwater plume at ST13 and DP26 by extracting groundwater from near the plume's distal end, if the plume is expanding. The groundwater extracted from the hydraulic containment well will be treated in the physical/chemical system.

- Notify the regulatory agencies of proposed dewatering activities, and evaluate their potential for impacting areas of groundwater contamination.

- Remove the drywell south of ST18 and test soils for contamination, if it can be located and removed without damaging the existing structures. If the drywell cannot be located, conduct confirmatory sampling.

- Monitor the groundwater near ST11, ST18, and selected SER sites, including SS31, to verify that contaminant concentrations, if any, remain within acceptable screening levels. Monitoring will continue for 5 years, at which time the need for further monitoring will be reevaluated.

- Implement institutional controls to prevent exposure to contaminated groundwater. In the event of base closure, any remaining contaminated sites will be addressed in accordance with CERCLA Section 120.

- Perform supplemental soil sampling during 1994 in the vicinity of Building 6214 (ST16) to confirm that no significant contamination remains.

The remediation will be implemented with a phased approach, where ongoing monitoring will evaluate the performance of each technology before proceeding to the next phase of cleanup. This phased approach will allow the U.S. Air Force to use field data collected during cleanup to get the best mix of technologies to meet cleanup objectives. Estimated costs are conservative because it was assumed that all components of the system will be required. If some of the components are not required, the actual costs may be significantly lower. 


\section{Statutory Determination}

The selected remedies are protective of human health and the environment, comply with Federal and State requirements that are legally applicable or relevant and appropriate to the remedial actions, and are cost effective. The remedies utilize permanent solutions and alternative treatment (or resource recovery) technologies to the maximum extent practicable and satisfy the statutory preference for remedies that employ treatment that reduces toxicity, mobility, or volume as a principal element.

Because these remedies will result in hazardous substances remaining onsite above healthbased levels, reviews will be conducted at sites ST10, SS14, ST13, DP26, and ST19 within 5 years after commencement of remedial action to ensure that the remedy continues to provide adequate protection of human health and the environment. 
Declaration for the Record of Decision..........................iii

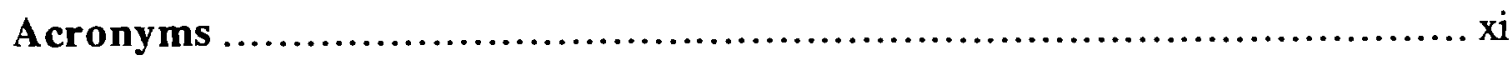

Decision Summary ....................................................... 1

1.0 Site Name, Location, and Description................................ 1

2.0 Site History and Enforcement Activities............................ 2

3.0 Highlights of Community Participation .............................. 3

4.0 Scope and Role of Operable Unit....................................... 4

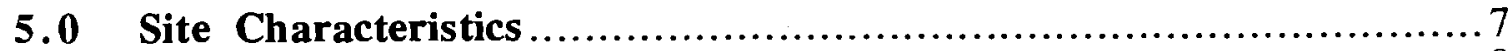

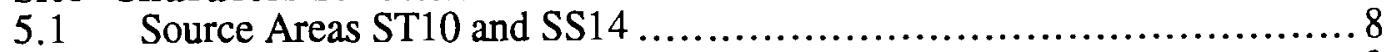

5.1.1 Soil Contamination.......................................... 9

5.1.2 Groundwater and Surface Water Contamination .................10

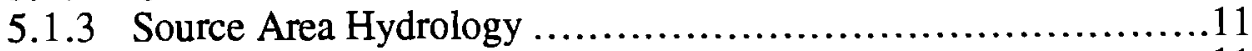

5.2 Source Area ST11 ..................................................

5.2.1 Soil Contamination.............................................. 11

5.2.2 Groundwater Contamination................................... 12

5.2.3 Source Area Hydrology ...................................... 13

5.3 Source Areas ST13 and DP26 .....................................13

5.3.1 Soil Contamination ......................................... 14

5.3.2 Groundwater Contamination................................... 15

5.3.3 Floating Fuel Contamination.......................................16

5.3.4 Source Area Hydrology .................................... 16

$5.4 \quad$ Source Area ST18 ................................................. 16

5.4 .1 Soil Contamination .......................................... 16

5.4.2 Groundwater Contamination........................................17

5.4.3 Source Area Hydrology ........................................... 18

5.5 Source Area ST19.................................................. 18

5.5.1 Soil Contamination............................................ 18

5.5.2 Groundwater Contamination...................................... 19

5.5.3 Source Area Hydrology ......................................... 19

5.6 Source Area LF05 ................................................... 19

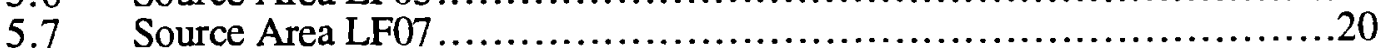

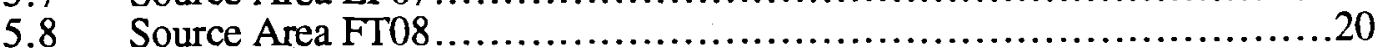

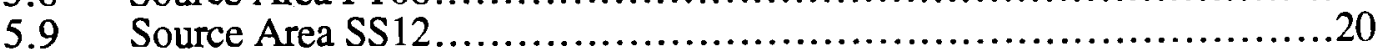

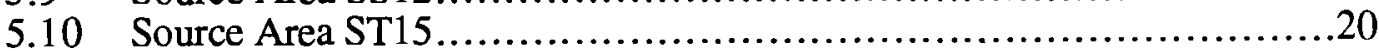

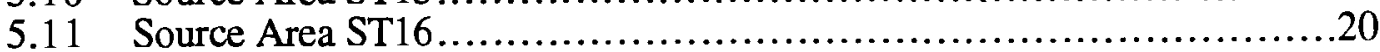

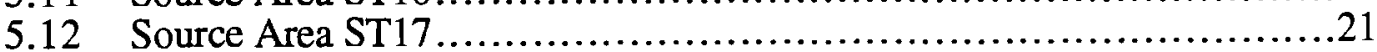

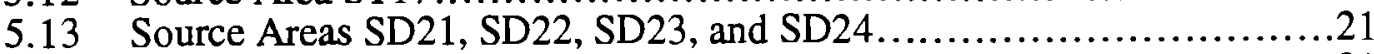

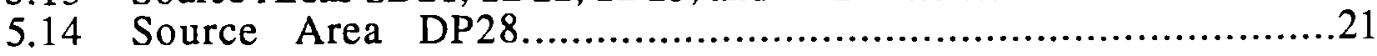




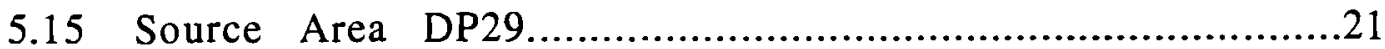

5.16 Source Areas SS30 and SS31 ...................................22

5.17 Source Area DP40................................................... 22

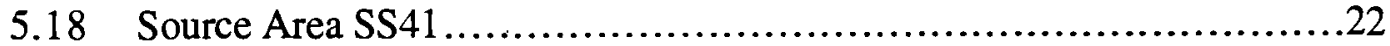

5.19 Source Area SS42 ................................................23

5.20 Source Area SS47 ....................................................23

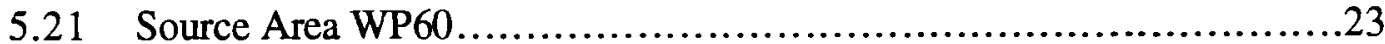

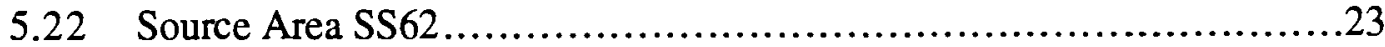

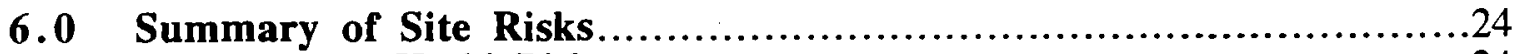

6.1 Human Health Risks..............................................24

6.1.1 Identification of Contaminants of Concern........................24

6.1.2 Exposure Assessment..............................................25

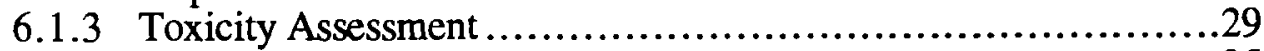

6.1.4 Risk Characterization ........................................ 35

6.1 .5 Uncertainty ................................................41

6.2 Environmental Risks............................................41

7.0 Description of Alternatives ........................................42

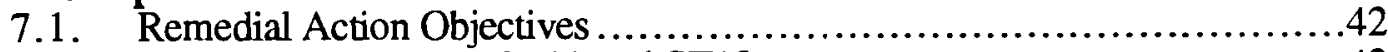

7.1.1 Source Areas ST 11 and ST18 ...............................42

7.1 .2 Source Area ST19....................................42

7.1.3 Source Areas ST10, SS14, ST13, and DP26.....................43

7.2. ST10 and SS14 Remedial Alternatives .............................44

7.2.1 Alternative 1: No Action Alternative.................................45

7.2.2 Alternative 2: Limited Action Alternative .......................45

7.2.3 Alternative 3: Bioventing Alternative...........................46

7.2.4 Alternative 4: Bioventing/Soil Vapor Extraction/Air Sparging/

Passive Skimming Alternative ...............................46

7.2.5 Alternative 5: Soil Excavation/Groundwater Treatment

Alternative ...................................................47

7.3 ST13 and DP26 Remedial Alternatives ...............................48

7.3.1 Alternative 1: No Action Alternative.................................48

7.3.2 Alternative 2: Limited Action Altemative .......................48

7.3.3 Alternative 3: Bioventing Alternative..........................48

7.3.4 Alternative 4: Bioventing/Soil Vapor Extraction/Air Sparging/ Active Skimming/Groundwater Treatment Alternative................49

7.3.5 Altemative 5: Soil Excavation/Groundwater Treatment Alternative

8.0 Summary of the Comparative Analysis of Alternatives ................50

8.1 Overall Protection of Human Health and the Environment.................50

8.2 Compliance with ARARs.............................................51

8.3 Long-Term Effectiveness and Permanence...............................51

8.4 Reduction of Toxicity, Mobility, or Volume Through Treatment ..........52

8.5 Short-Term Effectiveness ..........................................52

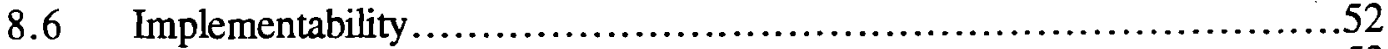

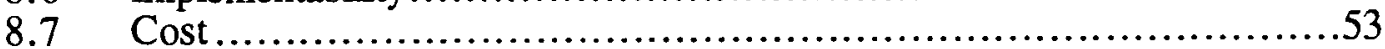

8.8 State Acceptance....................................................53

8.9 Community Acceptance..............................................54 


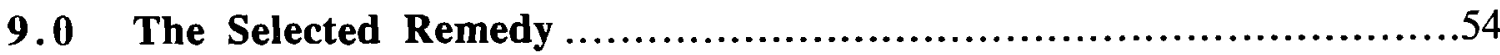

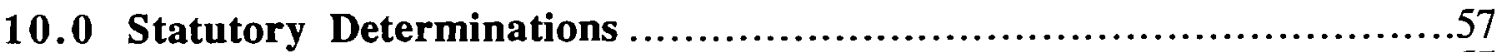

10.1 Protection of Human Health and the Environment ..........................57

10.2 Attainment of ARARs of Environmental Laws ...........................58

10.2.1 Applicable or Relevant and Appropriate Requirements..............58

10.2.1.1 Action-Specific .......................................58

10.2.1.2 Chemical-Specific ................................58

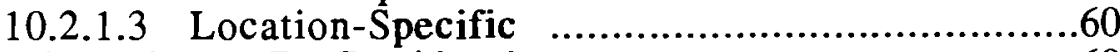

10.2.2 Information To-Be-Considered ...............................60

10.3 Cost Effectiveness.......................................................60

10.4 Utilization of Permanent Solutions and Alternative Treatment Technologies

to the Maximum Extent Practicable...........................................61

10.5 Preference for Treatment as a Principal Element.............................62

11.0 Explanation of Significant Differences $\ldots \ldots \ldots \ldots \ldots \ldots \ldots \ldots \ldots \ldots \ldots$

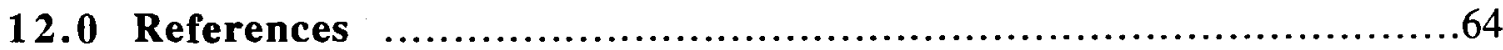

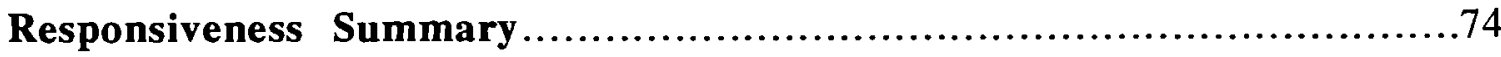

\section{TABLES}

1 ST10 and SS14-Subsurface Soil Contaminants of Concern ....................

2 ST10 and SS14-Groundwater Contaminants of Concern ....................... 10

3 BTEX Concentrations in ST10 Floating Fuel Samples.............................10

4 ST11-Benzene, 1,2-DCE, Total Lead, and Arsenic in Groundwater .............12

5 ST13-Subsurface Soil Concentrations of TPH, BTEX, and Lead ...............14

6 ST13 and DP26-Groundwater Concentrations of TPH, BTEX, and Lead........15

7 ST18--Semivolatile Organic Contaminants of Concern in Surface Soils ...........17

8 Contaminant of Concern Risk-Based Cutoff Values for BTEX ...................18

9 BTEX Analyses from Monitoring Well 19-02A................................19

10 Exposure Point Concentrations for ST10 and SS14 Risk Assessment ............25

11 Exposure Point Concentrations for ST11 Risk Assessment ......................26

12 Exposure Point Concentrations for ST13 and DP26 Risk Assessment.............27

13 Exposure Point Concentrations for ST18 Risk Assessment ......................28

14 Exposure Point Concentrations for ST19 Risk Assessment .....................29

15 Summary of Human Exposure Pathways for Source Area ST10 and SS14 .......30

16 Summary of Human Exposure Pathways for Source Area ST11 .................30

17 Summary of Human Exposure Pathways for Source Area ST13 and DP26.......31

18 Summary of Human Exposure Pathways for Source Area ST18 .................31

19 Summary of Human Exposure Pathways for Source Area ST19 ...................32

20 Toxicity Data Used for Risk Assessments .................................. 33

21 Summary of Cancer Risk and Hazard Index for the Reasonable Maximum Exposure Case at ST10/SS14..................................................37

22 Summary of Cancer Risk and Hazard Index for the Reasonable Maximum

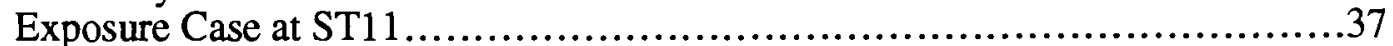

23 Summary of Cancer Risk and Hazard Index for the Reasonable Maximum Exposure Case at ST13/DP26 .......................................... 38 
24 Summary of Cancer Risk and Hazard Index for the Reasonable Maximum Exposure Case at ST18................................................38

25 Summary of Cancer Risk and Hazard Index for the Reasonable Maximum Exposure Case at ST19...........................................................39

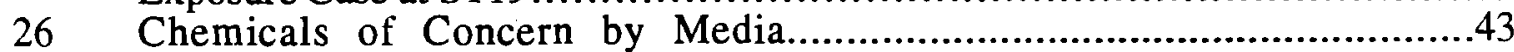

27 Remedial Action Objectives .................................................44

28 Final Remediation Goals .....................................................44

29 Relationship between ARARs and Remedial Alternatives........................45

30 Comparison of Cleanup Alternatives using the Five Balancing Criteria ............51

31 Cost of Remedial Alternatives ............................................54

32 Chemical-Specific ARARs for Chemicals of Concern..........................59

\section{FIGURES}

1 Location Map of Eielson Air Force Base .....................................67

2 Operable Unit 2 Source Areas ....................................................68

3 ST10 and SS14 Location Map ..............................................69

$4 \quad$ ST11 Location Map ....................................................... 71

$5 \quad$ ST13 and DP26 Location Map............................................. 73

6 ST18 Location Map ......................................................... 75

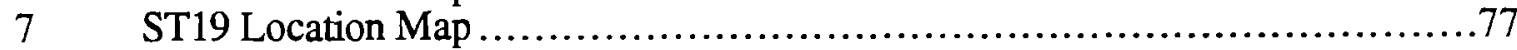




\section{ACRONYMS}

\begin{tabular}{|c|c|}
\hline$\sqrt{\overline{A A C}}$ & Alaska Administrative Code \\
\hline ADEC & Alaska Department of Environmental Conservation \\
\hline AFB & Air Force Base \\
\hline ARAR & applicable or relevant and appropriate requirement \\
\hline AVGAS & aviation gasoline \\
\hline AWQC & Ambient Water Quality Criteria \\
\hline BLRA & baseline risk assessment \\
\hline BSW & base supply well \\
\hline BTEX & benzene, toluene, ethylbenzene, and xylene \\
\hline CDI & chronic daily intake \\
\hline CERCLA & Comprehensive Environmental Response, Compensation, and Liability Act \\
\hline DCE & 1,2-dichloroethylene \\
\hline |DDD & 2,2-bis(para-chlorophenyl)-1,1-dichloroethane \\
\hline DDE & 1,1-dichloro-2,2-bis(para-chlorophenyl)-ethylene \\
\hline |DDT & dichlorodiphenyltrichloroethane \\
\hline DNAPL & dense non-aqueous phase liquid \\
\hline EPA & U.S. Environmental Protection Agency \\
\hline FFA & Federal Facility Agreement \\
\hline FNSB & Fairbanks North Star Borough \\
\hline FS & feasibility study \\
\hline |HI & hazard index \\
\hline |HLA & Harding Lawson Associates \\
\hline HQ & hazard quotient \\
\hline IIRP & Installation Restoration Program \\
\hline |JP-4 & Jet Propulsion No. 4 \\
\hline |JP-8 & Jet Propulsion No. 8 \\
\hline LNAPL & light non-aqueous phase liquid \\
\hline $\mathrm{MCL}$ & maximum contaminant level \\
\hline MCLG & maximum contaminant level goal \\
\hline MEPAS & Multimedia Environmental Pollutant Assessment System \\
\hline $\mathrm{mg} / \mathrm{kg}$ & milligrams per kilogram \\
\hline $\mathrm{mg} / \mathrm{L}$ & milligrams per liter \\
\hline MOGAS & motor gasoline \\
\hline NCP & National Contingency Plan \\
\hline ND & not detected \\
\hline NFA & no further action \\
\hline NPDES & National Pollutant Discharge Elimination System \\
\hline NPL & National Priorities List \\
\hline OSWER & Office of Solid Waste and Emergency Response \\
\hline OU & operable unit \\
\hline OU2 & Operable Unit 2 \\
\hline PAH & polycyclic aromatic hydrocarbon \\
\hline PCB & polychlorinated biphenyl \\
\hline PNL & Pacific Northwest Laboratory \\
\hline
\end{tabular}




\section{ACRONYMS (continued)}

\begin{tabular}{||ll||}
\hline POL & petroleum oil and lubricant \\
RAO & remedial action objective \\
RCRA & Resource Conservation and Recovery Act \\
RfD & reference dosage \\
RI & remedial investigation \\
RI/FS & remedial investigation and feasibility study \\
ROD & record of decision \\
SAIC & Science Applications International Corporation \\
SARA & Superfund Amendments and Reauthorization Act \\
SER & source evaluation report \\
SF & slope factor \\
SVE & soil vapor extraction \\
TCLP & Toxicity Characteristic Leaching Procedure \\
TOX & total organic halogens \\
TPH & total petroleum hydrocarbon \\
TRC & Technical Review Committee \\
$\mu$ G/L & micrograms per liter \\
UST & underground storage tank \\
VOC & volatile organic compound \\
yr & year \\
\hline
\end{tabular}




\section{Eielson Air Force Base \\ Operable Unit 2 and Other Areas \\ Record of Decision}

\section{Decision Summary}

\subsection{Site Name, Location, and Description}

Eielson Air Force Base (AFB) covers an area of approximately 19,270 acres, and it is located within the Fairbanks North Star Borough (FNSB) approximately 21 miles southeast of Fairbanks and 10 miles southeast of the city of North Pole, Alaska, along the Richardson Highway (Figure 1). Approximately 3,650 acres are improved or partially improved with the remaining land encompassing forest, wetlands, lakes, and ponds. The base is bounded on the east and south by Fort Wainwright, a U.S. Army installation, and on the west and north by private and public land. The base is isolated from major urban areas with the adjacent public and private land zoned general use. The approximate population of the FNSB, Fairbanks, and North Pole is 82,000, 32,000, and 1,600, respectively. Other communities near Eielson AFB include Moose Creek, which abuts the northern border of the base, and the Salcha area, which abuts the southern border of the base.

Eielson AFB is a major employer in the Fairbanks area. The base employs approximately 3,400 military personnel and 500 civilians. The total residential population of Eielson AFB is 5,132. The total population (living and working on the base) is approximately 10,000 . Residential and occupational populations are primarily concentrated in the developed portion of the base.

The area is active with ongoing base functions, including work, school, and recreational activities. The base contains three elementary schools and one junior-senior high school. There is one child care center and one medical and dental clinic.

The base is located in the Tanana River Valley. Most of the base has been constructed on fill material. The developed portion of the base's topography is generally flat and somewhat featureless with elevations averaging about 550 feet above mean sea level. The undeveloped east and northeast sides of the base are as high as 1,125 feet above mean sea level. Two-thirds of the base is covered with soils containing discontinuous permafrost. Half of the potential agricultural soils are currently being used for recreation facilities, ammunition storage areas, Arctic Survival Training School, and other Air Force developments. Significant wildlife frequents Eielson AFB. The base supports a variety of recreation and hunting opportunities. There are no resident threatened or endangered species on the base.

The developed portion of the base is underlain by a shallow, unconfined aquifer comprising of 200 to 300 feet of loose alluvial sands and gravel overlying relatively lowpermeability bedrock. The aquifer is characterized by high transmissivities and relatively flat groundwater gradients. Although there are significant seasonal fluctuations, groundwater is generally encountered at approximately 8 feet below grade. The groundwater generally flows to the north-northwest with the direction of flow locally 
influenced by surface water bodies (e.g., Garrison Slough and Hardifillit Lake) and groundwater extraction from the base supply wells.

Groundwater is the only source of potable water at the base and in the communities near the base. Potable water in the main base system is treated to remove irom and sulfide.

Groundwater is the principal source for various other industrial, domestic, agricultural, and fire-fighting purposes.

\subsection{Site History and Enforcement Activities}

Eielson AFB was established in 1944, and military operations have comtinued to the present. The mission of Eielson AFB is to train and equip personmel for close air support of ground troops in an arctic environment. Eielson AFB operations imclude industrial areas, aircraft maintenance and operations, an active runway and associated facilities, and administrative offices, as well as residential and recreation facilities.

In carrying out its defense mission, contamination of the soils and groundwater at the base has resulted from the storage and handling of fuels and solvents plus the operation of landfills. Initially this contamination was evaluated under the U.S. Air Force Installation Restoration Program (IRP). The four-phase IRP was initiated in 1982 with a Phase 1 record search to identify past disposal sites containing contaminants that may pose a hazard to human health or the environment. Under the IRP, the U.S. Air Force identified 64 potential areas of contamination at Eielson AFB. Potential source areas include old landfills, storage and disposal areas, fueling system leaks, and spill areas.

Eielson AFB was listed on the National Priorities List (NPL) (54 Fed Reg. 48184) on November 21, 1989, by the U.S. Environmental Protection Agency (EPA). This listing designated the facility as a federal Superfund site subject to the remedial response requirements of the Comprehensive Environmental Response, Compensation, and Liability Act (CERCLA), as amended by the Superfund Amendments and Reauthorization Act (SARA).

In May 1991, the U.S. Air Force, the State of Alaska, and EPA entered into a Federal Facility Agreement (FFA) (EPA et al. 1991) which established the procedural framework and schedule for developing, implementing, and monitoring CERCLA response actions. Under the FFA, the potential source areas were each placed in one of six operable units, based on similar contaminant and environmental characteristics, or were included for evaluation under a source evaluation report.

An additional goal of the FFA was to integrate U.S. Air Force's CERCLA response obligations and Resource Conservation and Recovery Act (RCRA) corrective action obligations. Thus, any remedial action implemented will be protective of human health and the environment such that remediation of releases shall obviate the need for further corrective action under RCRA (i.e., no further corrective action shall be required).

On December 7, 1980, Eielson AFB submitted an application to EPA to store hazardous waste and became subject to the applicable RCRA standards of a storage facility. These standards provide general operational requirements and closure standards when hazardous waste storage activities end. Building 3424, which was identified in the initial U.S. Air Force application as the hazardous waste storage facility, is included in this record of decision (ROD) as part of CERCLA source area SS31 and is otherwise subject to the RCRA closure requirements under 40 CFR $\S 265$, Subpart G. 
On June 15, 1988, the EPA and Eielson AFB signed a RCRA Federal Facility Compliance Agreement, which required Eielson AFB to pursue RCRA closure at specific hazardous waste management areas, including 1) the Building 3424 storage area - CERCLA source area SS31 and 2) Building 6214 - CERCLA source area ST16. These hazardous waste management areas are addressed in the ROD under CERCLA.

Several sites addressed within this ROD were used to manage hazardous waste subject to RCRA. RCRA gives EPA the authority to require waste management unit closure and cleanup measures for facilities that manage hazardous waste. The intent, as provided in this ROD, is to address the substantive closure requirements of these RCRA-regulated sites under CERCLA. This effort will minimize duplicative program actions while accomplishing functionally equivalent protective standards. Although certain sites may remain subject to additional administrative RCRA closure requirements, the substantive closure requirements of these sites are proposed to be accomplished solely under CERCLA.

\subsection{Highlights of Community Participation}

After the signing of the FFA (EPA et al. 1991) with the State of Alaska and the EPA, and the listing of Eielson AFB on the NPL, the U.S. Air Force began its Superfund cleanup program. As part of this program, in accordance with CERCLA Sections 113(k)(2)(B)(iv) and 117 , an extensive community relations program was initiated to involve the community in the decision-making process.

The community relations staff interviewed 40 local residents and community leaders to develop plans to keep residents informed about the cleanup activity at Eielson AFB. Follow-up interviews and questionnaires of more than 100 residents helped revise the Community Relations Plan. An environmental cleanup newsletter was created and mailed to anyone who wished to be on the mailing list. Fact sheets were prepared on various topics related to the cleanup operations. Several times a year articles that describe significant cleanup events are released to the base newspaper Goldpanner, as well as the Fairbanks Daily News Miner. All of these efforts are designed to involve the community in the cleanup process through comments they make when using this information.

The remedial investigation/feasibility study (RI/FS) (U.S. Air Force 1993a, 1993b, 1993c, 1993d) and Proposed Plan (U.S. Air Force 1993i) for Operable Unit 2 (OU2) of Eielson AFB were released to the public in November 1993. These two documents were made available to the public in both the administrative record and an information repository maintained at the Elmer E. Rasmusen Library at the University of Alaska, Fairbanks.

The public comment period on the Proposed Plan was held from November 8, 1993, through December 7,1993. This was extended until December 20, 1993, to compensate for a typographic error which required advertising the correction to the plan. A corrected addendum sheet was subsequently distributed to Proposed Plan recipients who were on the mailing list. Comments received during that period are summarized in the Responsiveness Summary of this ROD.

The Proposed Plan for OU2 was advertised twice in two local papers. The public comment period and public meeting were advertised on November 12 in the Goldpanner base paper. A 9-inch display ad that highlighted the cleanup efforts was placed in the North Pole Independent on November 5 and 12, and in the Fairbanks Daily News Miner on November 
5,15 , and 16. In addition, more than 3,500 copies were added as an insert in the base newspaper and delivered to every home in the Eielson AFB housing area. A news release announcing the Proposed Plan and public meeting was sent to all local news media (radio, television, and newspapers) and the story ran on the front page of the base newspaper. The meeting was advertised on the base access cable channel and in the base information bulletin as well as on at least one local area radio station. The base First Sergeants Group (the senior enlisted leadership for each unit on base) was briefed on the plan and public meeting to encourage their people to attend. Copies of the plan were delivered to various information repositories, plus the North Pole City Hall.

A public meeting was held on November 17, 1993. At this meeting, representatives from the U.S. Air Force, Alaska Department of Environmental Conservation (ADEC), and EPA answered questions about problems at the sites and the remedial alternatives under consideration. About 30 people attended.

A Technical Review Committee (TRC) was established in 1992 including three representatives for the community (selected by local officials and the University of Alaska Fairbanks Chancellor), industry representatives, and environmental agency representatives, and in November 1993, a local environmental interest group was invited to participate.

The Proposed Plan was presented to the TRC on November 16, 1993. At this meeting, representatives from the U.S. Air Force, ADEC, and EPA responded to questions from an audience representing the University of Alaska, the city of North Pole, and various State and federal agencies.

Public comments in response to the Proposed Plan and public meeting ranged from solid support of the plan as the best compromise among cleanup options to mild opposition against several of the no further action proposals. A few residents wanted more excavation, but none wanted to delay the process. Treating the source of continuing contamination (fuel-saturated soil) was supported as a good way to proceed at OU2, and some suggested the same methods should be applied at some of the fuel-contaminated SER source areas as well, even though the risk was within the acceptable levels. The specific comments and U.S Air Force responses are included in the Responsiveness Summary in this ROD.

\subsection{Scope and Role of Operable Unit}

As with many Superfund sites, the problems at Eielson AFB are complex. Thus, the FFA (EPA et al. 1991) divided the potential source areas at Eielson AFB into six operable units (OUs) and three source evaluation report (SER) groups based on common characteristics and contaminants.

The grouping of potential source areas into OUs was based on similar source characteristics or contaminants. The OUs are

OU 1 Petroleum, Oil, and Lubricant (POL) Contamination

OU 2 POL Contamination

OU 3 Solvent Contamination

OU 4 Land Disposal of Fuel Tank Sludge, Drums, and Asphalt

OU 5 Landfills

OU 6 Ski Lodge Well Contamination. 
An interim action at OU1B was initiated in June 1992 to initiate removal of petroleum products floating on top of the water table. OUs 1 and 6 are in the remedy selection process. OUs 3,4 , and 5 are in the RI/FS stage.

Six source areas with petroleum contamination were designated under OU2:

- ST10--E-2 POL Storage

- ST11--Fuel Saturated Area

- $\quad$ ST13--E-4 Diesel Fuel Spill

- SS14-E-2 Railroad JP-4 Fuel Spill Area

- ST18--Oil Boiler Fuel Saturated Area

- ST19--JP-4 Fuel Spill.

A seventh source area, the DP26--E-10 Fuel Tank Sludge Burial Site, was added to OU2 because of its geographical proximity, similar characteristics, and overlapping groundwater contamination with source area ST13. The source areas in OU2 are shown in Figure 2.

OU2 addresses sites contaminated by leaks and spills of fuels. Soils contaminated with petroleum products occur at or near the source of contamination. Contaminated subsurface soil and groundwater occur in plumes on the top of a shallow groundwater table that fluctuates seasonally. Most of the contamination is in subsurface soils and the shallow groundwater. Much of the groundwater contamination is believed to migrate from the smear zone because of fluctuations in the groundwater table, rather than infiltration from precipitation. These sites pose a risk to human health and the environment because of ingestion, inhalation, and dermal contact with contaminated groundwater. Also, there is the threat of further migration of contaminants into the groundwater from contaminated soils and petroleum products floating on top of the water table. The purpose of this response is to prevent current or future exposure to the contaminated groundwater, to reduce further contaminant migration into the groundwater, and to remediate groundwater.

Thirty-one other source areas are being evaluated through the source evaluation process. Based on the available information, these areas were believed to have a low probability of posing a significant risk to human health and the environment. Twenty-one of these source areas do not pose an unacceptable risk to human health and the environment, and are, therefore, recorded in this ROD for no further action.

This group of SER sites was evaluated in a screening assessment to determine if each source poses a risk to human health or the environment. The screening of contaminants compared the maximum concentration of each contaminant detected at the source area to a risk-based concentration calculated using a conservative target risk, calculated based on EPA standard default exposure factors assuming a residential scenario. The target risks used for this conservative screening were chosen based on the lower end of the $10^{-4}$ to $10^{-6}$ risk range specified in the NCP. The assumption used is that if no single sample exceeds a concentration representing a human health risk concern, total exposure to the contaminant from the source area will not be of concern. Specifically, the area required no further action if the maximum concentration detected was $\leq 10^{-6}$ cancer risk for water, $\leq 10^{-7}$ cancer risk for soil, and $\leq 0.1$ hazard quotient.

In addition, soil contaminant concentrations were evaluated to determine the potential for contributing to groundwater contamination. Soil screening levels for the soil-togroundwater pathway were determined based on fate and transport modeling to prevent exceedances of drinking water standards in the groundwater directly downgradient of the source area. 
All of the sites were found to contain contaminants below screening levels (e.g., maximum contaminant levels [MCLs], EPA Region 10 guidance) or the affected pathway was incomplete; therefore, no further action was required. These 21 SER sites are

- LF05--Old Army Landfill

- LF07--Test Landfill

- FT08--Fire Training Area (past)

- $\quad$ SS12--JP-4 Fuel Spill, Building 2351

- $\quad$ ST15--Multiproduct Fuel Line

- ST16--MOGAS Fuel Line Spill

- ST17--Canol Pipeline Spill

- SD21--Road Oiling--Quarry Road

- SD22--Road Oiling--Industrial Road

- SD23--Road Oiling--Manchu Road

- SD24--Road Oiling--Gravel Haul Road

- DP28--Fly Ash Disposal Site

- DP29--Drum Burial Site

- SS30--Polychlorinated Biphenyl (PCB) Storage Facility

- SS31--PCB Storage Facility

- DP40--Power Plant Sludge Pit

- SS41--Auto Hobby Shop (past)

- SS42--Miscellaneous Storage and Disposal Area

- SS47--Commissary Parking Lot Fuel Spill

- WP60--New Auto Hobby Shop

- SS62 --Garrison Slough.

The additional 10 SER sites are still undergoing a screening evaluation.

All of the source areas listed above have been evaluated under the U.S. Air Force IRP and the CERCLA RI/FS process. The studies listed below document preliminary investigations for most of these sites:

- 1982 IRP Phase I Records Search (CH2M Hill 1982)

- 1985 IRP Phase II Confirmation/Quantification Stage 1 Draft Report (Dames \& Moore 1985)

- 1986 through 1988 IRP RI/FS of the Fuel Saturated Area (SAIC 1989)

- 1989 IRP FS of the Fuel Saturated Area, Initial Screening of Remedial Technologies and Process Options (SAIC 1989)

- 1989 IRP FS of the Fuel Saturated Area, Development and Evaluation of Alternatives (SAIC 1989)

- 1989 IRP RI/FS Stage 3, Volume II (HLA 1989)

- 1990 IRP RI/FS, Stage 4, Volumes I through V (HLA 1990)

- 1991 IRP RI/FS, Stage 4, Volumes VII through XVIII (HLA 1991)

In addition, the following studies were conducted only for the OU2 source areas:

- 1993 RI/FS Final OU2 RI Report (U.S. Air Force 1993a)

- 1993 RJ/FS Final OU2 Baseline Risk Assessment (BLRA) (U.S. Air Force 1993c).

- 1993 RI/FS Final OU2 FS (U.S. Air Force 1993d).

The following study was conducted for the SER source areas:

- 1993 Final SER, Phase 1 (U.S. Air Force 1993g) 
A very brief history of each source area is provided in the following section.

\subsection{Site Characteristics}

Contamination at the OU2 sites has been investigated in detail since 1986. Science Applications International Corporation (SAIC 1989) conducted soil gas surveys and collected and analyzed soils, sediments, surface water, and groundwater in 1986, 1987, and 1988. CH2M Hill collected and analyzed soil, sediment, surface water, and groundwater samples in 1991 and 1992 . The data collected by SAIC were used to determine temporal changes in groundwater contaminant concentrations and were the source for most soils analyses at DP26. These data were not validated as completely as the 1991 and 1992 data sets. The analytical results are compiled in a U.S. Air Force report (1993b). Unless otherwise noted, all analytical data discussed in this ROD were collected during the 1991 field season.

There is only one aquifer for the OU2 source areas. The unconfined aquifer consists of alluvial sands and gravels. It is 200 to 300 feet thick and overlies crystalline bedrock (Birch Creek Schist). Within this unit, only the upper 60 to 90 feet were characterized during this investigation. The aquifer was found to be relatively homogeneous between areas of investigation. The layering of materials indicates a greater horizontal than vertical permeability.

The magnitude of the horizontal gradient was calculated for the OU2 source areas. The average horizontal gradient is approximately 0.001 foot/foot. Data from a pumping test, slug tests, and grain size analyses were used to estimate a hydraulic conductivity of approximately 200 feet/day.

Water levels from nested wells at source areas ST10, ST18, and DP26 were compared to provide information about vertical hydraulic gradients. The shallow wells generally have a 20 -foot screen, beginning near the top of the aquifer, which is approximately 10 feet below ground surface. The intermediate wells generally have a 10 -foot screen, beginning at approximately 30 feet below ground surface. Pressure head differences between the shallow and intermediate wells were smaller than the potential error of the instruments. Therefore, the vertical gradient is negligible.

The direction of groundwater flow is to the north-northwest. Locally, it is influenced by Garrison Slough, Hardfill Lake, and pumpage of base water supply wells. The direction of groundwater flow appears to be fairly constant year-round. Hardfill Lake is an old gravel pit, excavated to a depth below the groundwater table. The lake is within the ST10 and SS14 source areas.

Seasonal changes in water levels were interpreted using a precipitation hydrograph, snowpack data, and temperature data, primarily collected in 1991 and 1992. In general, the aquifer fluctuated uniformly across the site, indicating that similar hydrogeological conditions exist in the upper 100 feet of the aquifer at all source areas. Typically, the water table reaches its minimum elevation in November. During this period, the discharge from the aquifer to the Tanana River and its tributaries exceeds the recharge from precipitation. In April, the water table typically rises dramatically, and a maximum is observed in the last week of May. The maximum water level is about 1 to 2 feet higher than the minimum water level in November. This major recharge event coincides with the spring thaw, when 
runoff from the snow melt is at a maximum. The water table drops relatively rapidly after the end of May.

Two OU2 sites are adjacent to surface water bodies: Garrison Slough at ST11 and Hardfill Lake at ST10. The interrelationship between groundwater and surface waters at these sites is discussed within the site descriptions below.

Groundwater is the only source of potable water at Eielson AFB. This water is supplied by three large-capacity wells of 1,000 to 2,000 gallons per minute capacity. The base water supply wells are completed at depths averaging approximately 100 feet. Seven wells are designated to provide water to fight fires on the base and are designed for emergency use only. They are plumbed to the water supply system. In addition to the base water supply wells, there are 41 private wells within a 3-mile radius of the base, most of which are located downgradient of the base (north-northwest of the base) in or near the community of Moose Creek (Figure 1) and in agricultural areas west of the base (HLA 1991). The city of North Pole is served by a small public water supply system plus private wells.

\subsection{Source Areas ST10 (E-2 POL Storage) and SS14 (E-2 Railroad JP-4 Spill Area)}

Source areas ST10 and SS14 are discussed together in this ROD because they are located close to each other, have similar types of contaminants, and the individual releases to groundwater have created a joint groundwater contaminant plume.

The two sites are located in the southeastern developed portion of the base, along Quarry Road (Figure 3). ST10 includes the E-2 POL storage area and Hardfill Lake, which lies 200 feet northwest of the storage area. The storage area includes six 672,000-gallon, aboveground fuel tanks. Secondary containment dikes surround each of the tanks. A significant fuel spill within the Tank 6236 diked area was reported in 1967. Conflicting reports exist as to whether or not the spilled fuel overtopped the dikes. The tanks presently store JP-8 (arctic diesel). They have stored JP-4 and leaded fuels in the past. Oil sheens were observed on the surface of Hardfill Lake every spring and summer from at least 1978 to 1982 (CH2M Hill 1982).

SS14 is located immediately southwest of ST10. Until 1977, the area was used for rail delivery of fuel to the storage area. Currently, there are three truck refueling stands near Building 6221 and unloading headers from the fuel pipelines. These headers are located along the east side of the railroad line. The site is still actively used for offloading special fuels.

Base Supply Well 14 (BSW14) is located in Building 6224, approximately 240 feet southwest of ST10. BSW14 is one of four base water supply wells. It is used for a toilet, sinks, and an emergency shower in Building 6224. Although routine testing indicates this water is suitable for drinking, the well does not meet separation distances from a contamination source as required by state of Alaska Drinking Water Standards. Bottled drinking water is supplied at Building 6224. No other base water supply wells are within 500 feet of ST10 or SS14.

There are two RCRA-related areas that are geographically associated with ST10. By joint agreement between the U.S. Air Force, EPA, and ADEC, these two areas are being addressed in conjunction with ST10. One of these areas is a former drum storage area used from 1976 through 1993. Approximately 450 drums were removed, with final sampling and removal occurring in June 1993. The other area was used to store sandblasting grit. Six tanks were sandblasted to remove the old lead-based primer. The resulting material 
was put in drums and stored for about 1 year. Storage of these drums resulted in a RCRA Notice of Violation in 1990. These drums have been removed and disposed of through the U.S. Air Force hazardous materials program. The presence of residual contamination at both of these areas will be evaluated, as appropriate, as part of the CERCLA action for ST10 and SS14.

Source areas ST10 and SS14 both contain soil and groundwater contaminated by fuel spills and leaks. In addition, there is a layer of fuel floating atop the groundwater at the sites. The probable contaminant sources at ST10 are leaks from the storage tanks and their associated piping. The probable sources at SS14 are leaks from fuel lines and numerous fuel spills that occurred during unloading and refueling operations along the railroad and truck fuel transfer stations.

\subsubsection{ST10 and SS14 Soil Contamination}

Surface, subsurface, and sediment soil samples were collected at ST10 and SS14 during 1991 and 1992.

Surface soil lead concentrations at ST10 ranged from 7.8 to $174 \mathrm{mg} / \mathrm{kg}$. Total petroleum hydrocarbon (TPH) concentrations exceeded $100 \mathrm{mg} / \mathrm{kg}$ in all directed surface soil samples. Seven of the 15 composite soil samples exceeded $100 \mathrm{mg} / \mathrm{kg} \mathrm{TPH}$.

TPH analyses were performed for all subsurface soil and sediment samples. Two samples from each boring were analyzed for benzene, toluene, ethylbenzene, and xylene (BTEX) compounds. Table 1 lists the subsurface soil contaminants of concern.

\begin{tabular}{||l|c|c|c|c||}
\hline \multicolumn{5}{|c|}{ TABLE 1. ST10 and SS14-Subsurface Soil Contaminants of Concern } \\
\hline \hline Constituent & $\begin{array}{c}\text { Detection } \\
\text { Limit } \\
(\mu \mathrm{g} / \mathrm{kg})\end{array}$ & Detected/Analyzed & $\begin{array}{c}\text { Concentration Range Detected } \\
(\mu \mathrm{g} / \mathrm{kg})\end{array}$ & $\begin{array}{c}\text { Location of Maximum } \\
\text { Concentration } \\
\text { Depth in feet) }\end{array}$ \\
\hline TPH & $1700-50000$ & $97 / 161$ & $11,100-36,423,000$ & $14 \mathrm{SB} 16-8.0$ \\
\hline Benzene & $20-690$ & $18 / 65$ & $6 \mathrm{~J}-9200 \mathrm{DJ}$ & $14 \mathrm{SB} 01-3.0$ \\
\hline Ethylbenzene & $5-660$ & $34 / 65$ & $15-54000 \mathrm{D}$ & $14 \mathrm{SB} 01-3.0$ \\
\hline Ooluene & $5-20$ & $52 / 65$ & $1 \mathrm{~J}-33000 \mathrm{D}$ & $14 \mathrm{SB} 01-3.0$ \\
\hline Xylenes & $5-20$ & $45 / 65$ & $30-530,000 \mathrm{D}$ & $14 \mathrm{SB} 01-3.0$ \\
\hline \hline
\end{tabular}

At ST10, TPH contamination in excess of $1,000 \mathrm{mg} / \mathrm{kg}$ occurs beneath the tank farm and extends northwest to Hardfill Lake. TPH concentrations in the borings collected near the tank farm increase with depth and are greatest in the zone of groundwater table fluctuation (referred to as the smear zone).

Assuming that the TPH contamination remaining at ST10 is the result of a significant fuel spill within the bermed area, it appears that the fuel infiltrated downward to the groundwater table, initially spread in all directions, then migrated downgradient towards Hardfill Lake.

There appear to be two discrete locations of elevated TPH contamination at SS14. One area is located near the JP-4 fuel distribution headers at the southeast end of SS14. The other area is to the northwest, close to buried, abandoned motor gasoline (MOGAS) and diesel 
fuel lines. Both locations have soil TPH concentrations greater than $35,000 \mathrm{mg} / \mathrm{kg}$ in the smear zone of the groundwater table.

Volatile organic compounds were detected at SS14 in the soil near the areas of TPH contamination.

\subsubsection{ST10 and SS14 Groundwater and Surface Water Contamination, and Floating Fuel}

Table 2 lists the concentrations of contaminants detected in groundwater samples collected at ST10 and SS14.

The only volatile organic compound detected in surface waters (Hardfill Lake) was benzene, at a concentration of $2 \mu \mathrm{g} / \mathrm{L}$ in one sample. No semivolatile organic compounds, pesticides, PCBs, or TPH were detected in surface waters. Metals' concentrations in surface waters were similar to groundwater, except for total lead that had a maximum concentration of $1.7 \mu \mathrm{g} / \mathrm{L}$.

\begin{tabular}{|c|c|c|c|c|}
\hline Constituent & $\begin{array}{c}\text { Detection Limit } \\
(\mu \mathrm{g} / \mathrm{L})\end{array}$ & Detected/Analyzed & $\begin{array}{c}\text { Concentration Range Detected } \\
(\mu g / L)\end{array}$ & $\begin{array}{c}\text { Location of } \\
\text { Maximum Concentration }\end{array}$ \\
\hline $\mathrm{TPH}$ & 50 & $7 / 13$ & $810-532,000$ & 10MW08 \\
\hline Benzene & 5 & $8 / 13$ & $1 \mathrm{~J}-1300 \mathrm{D}$ & 10MWO1 \\
\hline Toluene & 5 & $6 / 13$ & $2 J-9500 D$ & 10MW01 \\
\hline Total lead & 3 & $12 / 14$ & $1.9 B-45.7$ & 10MW01 \\
\hline
\end{tabular}

Floating fuel was detected in two monitoring wells in 1991. The floating fuel samples from both wells were identified in 1991 as JP-4. Two samples of the floating fuel were taken from one of these wells in 1992. The samples were analyzed in 1992 by Pacific Northwest Laboratory (PNL) for BTEX. The results are in Table 3.

\begin{tabular}{||c|c|c|c|c|}
\hline \multicolumn{4}{|c|}{ TABLE 3. BTEX Concentrations in ST10 Floating Fuel Samples } \\
\hline \hline Well & $\begin{array}{c}\text { Benzene } \\
(\mathrm{mg} / \mathrm{L})\end{array}$ & $\begin{array}{c}\text { Toluene } \\
(\mathrm{mg} / \mathrm{L})\end{array}$ & $\begin{array}{c}\text { Ethylbenzene } \\
(\mathrm{mg} / \mathrm{L})\end{array}$ & $\begin{array}{c}\text { Total Xylenes } \\
(\mathrm{mg} / \mathrm{L})\end{array}$ \\
\hline $10-8$ & 266 & 6420 & 772 & 5144 \\
\hline $10-8$ & 271 & 6186 & 800 & 4902 \\
\hline
\end{tabular}

In 1992, additional characterization of the floating fuel occurred. Eighteen product probes were installed at ST10 to determine the extent of floating fuel. Results suggest that there are two separate coalescing plumes that intersect at Hardfill Lake. The source for one plume appears to be Tank 6238. The thickness of floating fuel in this plume appears to fairly thin $(<0.3 \mathrm{feet})$. The source for the other plume appears to be the truck fueling station in SS14. This plume appears to be much thicker ( $\leq 1.48$ feet). The distribution headers at SS14 were pressure tested in 1993, and the leaking pipes were replaced. The total volume of floating product was estimated at 48,000 gallons (Appendix A of U.S. Air Force 1993d). 
Groundwater plumes of benzene, toluene, TPH, and total lead were identified during the 1991 field season. The highest benzene concentrations in shallow groundwater occur beneath the tank farm and extend toward Hardfill Lake. It appears that groundwater contaminated with benzene and toluene flows directly into Hardfill Lake. Shallow groundwater contamination at concentrations exceeding the Safe Drinking Water Act MCLs and action levels were identified for benzene, toluene, and lead. The highest TPH concentrations occur in the same monitoring wells that contain floating product.

Two sets of nested wells, wells completed at different depths in the aquifer, were installed at ST10. The shallow wells are screened from 5 to 30 feet below the ground surface; the intermediate wells are screened from 30 to 50 feet below the ground surface. The two shallow wells had significant groundwater contamination (e.g., benzene at $1300 \mathrm{D}$ and 430 $\mathrm{D} \mu \mathrm{g} / \mathrm{L})$; the only contaminant detected in the intermediate wells was benzene at $2 \mathrm{~J} \mu \mathrm{g} / \mathrm{L}$ in one. No other volatile and no semivolatile organic compounds were detected in either well. No volatile or semivolatile organic compounds were detected in the sample collected from BSW-14. BSW-14 is screened from 86 to 96 feet. The well supplies water to Building 6224.

\subsubsection{ST10 and SS14 Source Area Hydrology}

The groundwater flow direction at ST10 and SS14 is to the northwest with a calculated horizontal hydraulic gradient of 0.002 foot/foot. Staff gage readings from Hardfill Lake indicate that lake waters are lower than the water table elevations at ST10, indicating that groundwater discharges to the lake in this area. Groundwater in the area of the railroad fueling facility flows to the northwest, then to the north and discharges into Hardfill Lake.

\subsection{Source Area ST11 (Fuel Saturated Area)}

Source area ST11 consists of subsurface diesel fuel contamination associated with one building, Building 3224, situated along the southeastern side of Garrison Slough (Figure 4). The building was built before June 1956, and initially was used as the base bakery. The bakery used diesel-fired ovens fueled by a 4-inch pipeline. The pipeline probably came from several diesel tanks buried on the east side of Central Avenue. The tanks have been removed. By 1981, the site had been converted to a dog training facility.

In 1975, a sheen was discovered atop the waters of Garrison Slough alongside ST11. An investigation discovered a petroleum diesel fuel, refined around 1950, floating on groundwater next to Building 3224.

A cleanup action followed from 1977 to 1980 . A 4-inch pipeline that still contained some diesel was removed in 1977. An oil-water separator was used in several excavated trenches until 1980 for the removal of a floating fuel layer.

\subsubsection{ST11 Soil Contamination}

Samples were collected at ST11 in 1991 to identify the nature and extent of contamination in surface and subsurface soils.

Lead was the only contaminant of concern detected in surface soil samples collected at ST11. Lead concentrations in composite surface soil samples collected at ST11 ranged from 8 to $95 \mathrm{mg} / \mathrm{kg}$. The locations of samples containing high lead concentrations are near Central Avenue and are attributed to vehicle traffic. 
High TPH values were detected in soil samples at the groundwater smear zone. In most of the soil borings, the highest TPH concentration occurred at the lowest sample depth, just below the water table where values ranged from 1,260 to $23,500 \mathrm{mg} / \mathrm{kg}$. The highest TPH concentrations were detected adjacent to Building 3224. The extent of contaminated soils beneath Building 3224 is unknown. No elevated TPH values were detected north of Garrison Slough. BTEX concentrations in the subsurface soil samples were all below the levels of concern for protection of groundwater. The potential for the soil contamination to act as a future source of groundwater contamination was evaluated in the OU2 RI (U.S. Air Force 1993a), and the results of fate and transport modeling indicate that groundwater contaminant concentrations are not expected to exceed regulatory levels.

Volatile organic compounds were not detected in most of the soil samples with elevated TPH concentrations. BTEX, where detected, was at low concentrations, which suggests that the diesel fuel has weathered since the spill or leak occurred, thus removing the lighter fractions. Only the heavier fractions of the fuel appear to have remained in the soil.

The concentration of TPH contamination at 9 to 13 feet is consistent with the probable contaminant history at ST11. The most likely source for the contamination was the buried pipe that contained diesel fuel. Under the influence of gravity, the diesel would have spread out of the pipe and sunk to the top of the groundwater table. Here it would have spread laterally atop the water, both upgradient and downgradient, forming a floating fuel layer.

\subsubsection{ST11 Groundwater Contamination}

Benzene, 1,2-dichloroethylene (DCE), total lead, and arsenic concentrations detected in ST11 groundwater samples are listed in Table 4. No concentrations of volatile or semivolatile organic compounds above the risk-based levels of concern were identified in groundwater samples collected at ST11. TPH was detected in groundwater with a maximum concentration of $90 \mu \mathrm{g} / \mathrm{L}$. The TPH soil contamination at the groundwater table smear zone appears to have weathered sufficiently to remove volatile organic compounds and water soluble semivolatile organic compounds from the groundwater.

\begin{tabular}{|c|c|c|c|c|}
\hline Constituent & $\begin{array}{c}\text { Detection Limit } \\
(\mu \mathrm{g} / \mathrm{L})\end{array}$ & Detected/Analyzed & $\begin{array}{c}\text { Concentration Range Detected } \\
(\mu \mathrm{g} / \mathrm{L})\end{array}$ & $\begin{array}{c}\text { Location of } \\
\text { Maximum Concentration }\end{array}$ \\
\hline Benzene & 5 & $1 / 7$ & $1 \mathrm{~J}$ & $11 \mathrm{MWO3}$ \\
\hline 1,2-DCE & 5 & $1 / 7$ & $1 \mathrm{~J}$ & $11 \mathrm{MW} 07$ \\
\hline Total lead & 1 & $7 / 7$ & $1.3 B-4.5$ & $11 \mathrm{MWO6}$ \\
\hline Arsenic & 10 & $7 / 7$ & $1.1 \mathrm{~B}-60$ & $11 M W 04$ \\
\hline
\end{tabular}

Arsenic was detected at a concentration of $60 \mu \mathrm{g} / \mathrm{L}$ in one ST11 well during 1991. This well has since been sampled twice, and both times the arsenic concentrations were below the MCL of $50 \mu \mathrm{g} / \mathrm{L}$ (U.S. Air Force 1993g). Arsenic concentrations are variable and are dependent upon seasonal groundwater levels and the natural oxidation state. The elevated level of arsenic detected at ST11 is not assumed to be the result of contamination. In addition, past activities at Eielson AFB are not expected to have generated arsenic contamination. 


\subsubsection{ST11 Source Area Hydrology}

Staff gage measurements from Garrison Slough adjacent to ST11 show that surface water elevations are usually higher than groundwater elevations. This indicates that in the vicinity of ST11, Garrison Slough loses water to the aquifer at all times except during spring thaw, from about late April to late June.

\subsection{Source Areas ST13 (E-4 Diesel Fuel Spill) and DP26 (E-10 Fuel Tank Sludge Burial Site)}

Source areas ST13 and DP26 are discussed together because they are located close to each other, have similar types of contaminants, and the individual releases to groundwater have created an overlapping groundwater contaminant plume.

Source area ST13 is located along the southeast end of the main taxiway west of Flightline Avenue (Figure 5). The area contains a fuel pump house (Building 1240), ten underground fuel storage tanks, five fuel outlets (1,2,3,4, and 4.5), and an area used in the past for filling and storing fuel bladders.

Source area DP26 is located directly across Flightline Avenue and includes a 420,000gallon aboveground storage tank (Tank 300 [Structure 4482]) and ancillary piping, shallow trenches used for the burial of sludge from fuel tank cleaning operations, an area where fuel-saturated soil removed during replacement of Tank 300 in 1987 was placed, and truck fill stands near Building 4480. Two underground tanks of JP-4 near Building 1240 were reported leaking to ADEC in November 1990. The amount of fuel leaked is unknown. Those tanks were part of the fuel hydrant system associated with Building 1240. The two tanks were taken out of service in 1990.

Activities at both sites currently support the refueling of aircraft along the flightline. This area has been used for the fueling of aircraft and other vehicles since Eielson AFB operations began in World War II. The following fuels have been stored and dispensed here: aviation gasoline (AVGAS), MOGAS, JP-4, and JP-8. JP-4 and JP-8 (arctic diesel) are currently stored at these sites.

Contamination of soil and groundwater at ST13 resulted from the rupture or overfill of fuel bladders filled in the area, and from leaks or spills from underground storage tanks and fuel outlets in the area. The fuel bladders were used primarily to transport diesel fuel or MOGAS to remote locations. The bladders were filled from outlets on the flightline, then placed in a staging area within ST13 for transport. This process was discontinued in spring 1992. Two underground tanks of JP-4 near Building 1240 were reported leaking to Alaska Department of Environmental Conservation (ADEC) in November 1990. The amount of fuel leaked is unknown. Those tanks were part of the fuel hydrant system associated with Building 1240. The two tanks were taken out of service in 1990, and the system components were purged of fuel. The underground fueling system that connects Tank 300 with the pump house and the five fuel outlets is scheduled for replacement in 1994. An estimated 12,000 cubic yards of soil will be excavated during this replacement; of this volume, 7,000 cubic yards are believed to be contaminated. These soils are among the most contaminated at the site, and they will be excavated and treated outside of the CERCLA process as part of the construction project.

Contamination of soil and groundwater at DP26 probably resulted from leaks and spills from Tank 300, its associated underground piping, and the truck fill stands. Tank 300 was replaced in 1987. During the replacement of the tank, fuel-saturated soil was encountered beneath the tank. The soil was removed and replaced with clean soil. 
Weathered sludge from periodic fuel tank cleaning operations reportedly was buried in shallow trenches. The sludge consisted of predominantly water with some rust, soil, and fuel. Disposal of sludge in this manner occurred from 1955 until 1980. These burial areas were not located during the remedial investigation.

No active base water supply wells are within 500 feet of ST13 or DP26. The main base supply well (BSW-D) is 6,800 feet north of ST13.

\subsubsection{ST13 and DP26 Soil Contamination}

Samples were collected from surface soils and subsurface soil borings at ST13 during the 1991 field season. Soil samples were collected from DP26 during the 1986, 1987, and 1988 field seasons.

Lead, DDTs, TPH, and polycyclic aromatic hydrocarbons (PAHs) were detected in the surface soils at ST13. The maximum lead concentration detected in surface soil samples was $88.3 \mathrm{mg} / \mathrm{kg}$. The proximity of these sample locations to Flightline Avenue suggests that the surface lead concentration is caused by vehicular exhaust from heavy traffic.

Four of the five ST13 surface soil samples exhibited elevated concentrations of 2,2bis(para-chlorophenyl)-1,1-dichloroethane (4,4-DDD), 1,1-dichloro-2,2-bis(parachlorophenyl)-ethylene (4,4-DDE), and dichlorodiphenyltrichloroethane (4,4-DDT). The maximum DDT concentration was $814 \mu \mathrm{g} / \mathrm{kg}$. DDT was not detected in background soil samples. Again, the proximity of the sample location to Flightline Avenue suggests that past base operations, including spraying for insect control along the roadway, may be responsible for the pesticide residue detected in the sample.

The maximum concentration of TPH in a composite surface soil sample is $814 \mathrm{mg} / \mathrm{kg}$. TPH concentrations in the other two surface soil samples along Flightline Avenue were also above $100 \mathrm{mg} / \mathrm{kg}$. High TPH concentrations in the surface soil may be attributable to vehicular traffic emissions or road maintenance activities. Similarly, PAHs were also detected along Flightline Avenue. The semivolatile organic compounds are assumed to be the products of uncompleted combustion of diesel fuel, or the residual components of road maintenance materials.

Table 5 lists the concentrations of TPH, BTEX, and lead detected in subsurface soil samples at ST13. Subsurface soil samples from DP26 were analyzed by SAIC (1989). However, they were not included because the data were not validated as completely as the 1991 and 1992 data sets. Based on the subsurface soil investigation at ST13, there appear to be two areas of elevated TPH contamination. One area is near a 25,000-gallon underground diesel storage tank. The other area identified is near Building 1240. The highest TPH concentrations in subsurface soil samples occurred above the groundwater table smear zone.

\begin{tabular}{|c|c|c|c|c|}
\hline Constituent & $\begin{array}{c}\text { Detection Limit } \\
(\mathrm{mg} / \mathrm{kg})\end{array}$ & Detected/Analyzed & $\begin{array}{c}\text { Concentration Range Detected } \\
(\mathrm{mg} / \mathrm{kg})\end{array}$ & $\begin{array}{c}\text { Location of } \\
\text { Maximum Concentration } \\
\text { (Depth in feet) }\end{array}$ \\
\hline TPH & $1.9-50$ & $41 / 55$ & $6.7-31400$ & $13 S B C-12.7$ \\
\hline Benzene & $0.005-0.65$ & $6 / 36$ & $0.02-20$ & $13 S B C-12.7$ \\
\hline Toluene & $0.005-0.65$ & $10 / 36$ & $0.02-220$ & $13 S B C-12.7$ \\
\hline Lead & & $3 / 3$ & $14.5-60.4$ & $13 S B C-07.5$ \\
\hline
\end{tabular}


The TPH contamination at the underground diesel storage tank resulted from either spills associated with the fuel bladder fill operation, a leak in the storage tank, or contamination from Tank 300, located immediately to the east across Flightline Avenue.

BTEX compounds were detected in the soil boring samples that also had high TPH concentrations. The contamination at one area may be the result of a fuel leak from underground JP-4 storage tanks at Building 1240. The high BTEX concentrations detected in soil boring samples ( $20 \mathrm{mg} / \mathrm{kg}$ benzene at 12.7 feet depth) may indicate a recent source of contamination. As stated previously, a spill from Building 1240 was reported to ADEC in 1990.

\subsubsection{ST13 and DP26 Groundwater Contamination}

Table 6 lists the concentrations of TPH, BTEX, and total lead for groundwater samples collected from ST13 and DP26 monitoring wells.

\begin{tabular}{|c|c|c|c|c|}
\hline Constituent & $\begin{array}{c}\text { Detection Limit } \\
(\mu \mathrm{g} / \mathrm{L})\end{array}$ & Detected/Analyzed & $\begin{array}{c}\text { Concentration Range Detected } \\
(\mu \mathrm{g} / \mathrm{L})\end{array}$ & $\begin{array}{c}\text { Location of } \\
\text { Maximum Concentration }\end{array}$ \\
\hline TPH & 50 & $3 / 5$ & $100-101,000$ & 13MW02 \\
\hline Benzene & 5 & $18 / 22$ & $1 \mathrm{~J}-1400$ & $26 \mathrm{MW} 08$ \\
\hline Ethylbenzene & 5 & $13 / 22$ & $1 \mathrm{~J}=1100$ & $26 \mathrm{MW} 01$ \\
\hline Toluene & 5 & $13 / 22$ & $2 \mathrm{~J}-4200$ & 26MW08 \\
\hline Thotal lead & 1 & $15 / 20$ & $1.3 \mathrm{~B} \cdot 795$ & $26 \mathrm{MW} 08$ \\
\hline
\end{tabular}

The area of benzene contamination identified by an SAIC study in 1988 and sampling done in the 1991 field season is narrow in width and elongated in the direction of groundwater flow. Based on a comparison of the two studies, the benzene contamination appears to have migrated approximately 600 feet in 3 years. The distal end of the benzene contaminant plume was resampled in June 1992. A comparison of the results from the SAIC 1988 study and the 1991 and 1992 field seasons show that benzene concentrations have declined significantly. The toluene and total lead contaminant plumes are centered in the same location as the benzene plume.

There are a number of storage tanks and buried fuel pipelines located at ST13 and DP26 in the area of highest groundwater contamination. Spills or leaks from these facilities are the identified sources of past contamination.

The decline in BTEX contamination noted previously suggests that either the source of contamination is no longer active and the more mobile contaminants are dispersing, or groundwater conditions are responsible for plume changes over time. The probable source, Tank 300, was replaced in 1987 . While no continuing releases are suspected, fuel contamination in soil and floating fuel on the groundwater may be a continuing source for contaminants dissolved in the groundwater.

The lead contamination probably resulted from old spills or leaks that occurred when leaded fuels were used. The U.S. Air Force quit using leaded fuels in the mid-1970s. 


\subsubsection{ST13 and DP26 Floating Fuel Contamination}

Floating fuel was identified and measured in 1991 in two groundwater monitoring wells. $\mathrm{CH} 2 \mathrm{M}$ Hill analyzed a sample of the floating fuel and identified it as either JP-4 or Jet A. The BTEX concentration of floating fuel in one sample showed benzene at $363 \mathrm{mg} / \mathrm{L}$, toluene at $5,226 \mathrm{mg} / \mathrm{L}$, ethylbenzene at $2,368 \mathrm{mg} / \mathrm{L}$, and total xylenes at $13,975 \mathrm{mg} / \mathrm{L}$. To define the location and extent of the floating fuel at DP26, 11 product probes were installed in 1992. The thickness of the floating fuel layer ranges between 0.06 feet and 1.13 feet leading to an estimated volume of 7,000 gallons (U.S. Air Force 1993d). Tank 300 is the likely source of the floating fuel product.

\subsubsection{ST13 and DP26 Source Area Hydrology}

The groundwater flow direction at ST13 and DP26 is to the north-northwest with a calculated horizontal hydraulic gradient of 0.0013 foot/foot. Groundwater near Garrison Slough appears to be flowing towards and discharging to the slough. Extensive dewatering activities during construction projects may have affected the groundwater gradient and contaminant plumes.

\subsection{Source Area ST18 (Oil Boiler Fuel Saturated Area)}

Source area ST18 is described as an old boiler plant (CH2M Hill 1982). The site presently includes four buildings (Buildings 3405, 3409, 3411, and 3386) (Figure 6) and is adjacent to ST48, a source being addressed in OU1. Building 3405 is the old boiler plant that is currently used for salvaging old vehicles before their use as targets. Buildings 3409 and 3411 contain backup diesel generators. Building 3386 is the Precision Measuring Equipment Laboratory where electronic gear is calibrated: ST18 also contains two 25,000gallon storage tanks buried east of Building 3405. The tanks are currently filled by tanker trucks with arctic diesel, and they supply the generators in Buildings 3409 and 3411 . They have been in use since 1948. Tank "tightness" testing in August 1993 and soils information from the RI indicate that the tanks have leaked, and they will be removed in cooperation with the state of Alaska under another compliance program.

Contamination was first reported at ST18 during the mid-1970s, when a series of 8-footdeep holes were excavated for installation of electrical wiring. A floating hydrocarbon layer was detected atop the water table in the excavations. The source of the contamination was not identified, and there is no record of any remediation or repairs.

\subsubsection{ST18 Soil Contamination}

TPH was detected in all ST18 surface soil samples, with a maximum concentration of 976 $\mathrm{mg} / \mathrm{kg}$. Lead was also detected in all surface soil samples with a maximum concentration of $94.9 \mathrm{mg} / \mathrm{kg}$.

Several semivolatile organic compounds were detected in two composite surface soil samples (Table 7). Both samples were obtained along the railroad right-of-way on the west side of ST18.

The PAHs present are characteristic of diesel exhaust, probably from long-term operation of diesel engines. The most likely source is the Diesel Locomotive Repair Shop (Building 3383), which is just north of the contamination. This shop is used for locomotive repair, and the tuning of the large diesel power plants in locomotives is a reasonable source for PAH contamination. 


\begin{tabular}{||l|c|c|c||}
\hline \multicolumn{2}{|c|}{ TABLE 7. ST18 Semivolatile Organic Contaminants of Concern in Surface Soils } \\
\hline \hline Contaminant of Concern & $\begin{array}{c}\text { Detection Limit } \\
(\mu \mathrm{g} / \mathrm{kg})\end{array}$ & $\begin{array}{c}\text { Detected/Analyzed } \\
\text { Anthracene }\end{array}$ & $\begin{array}{c}\text { Concentration Range Detected } \\
(\mu \mathrm{g} / \mathrm{kg})\end{array}$ \\
\hline Benzo(a)anthracene & 690 & $1 / 5$ & $73 \mathrm{~J}$ \\
\hline Benzo(a)pyrene & 690 & $1 / 5$ & $430 \mathrm{~J}$ \\
\hline Benzo(b)fluoranthene & 690 & $2 / 5$ & $150 \mathrm{~J}-550 \mathrm{~J}$ \\
\hline Benzo(g,h,i)perylene & 690 & $2 / 5$ & $88 \mathrm{~J}-460 \mathrm{~J}$ \\
\hline Benzo(k)fluoranthene & 690 & $2 / 5$ & $430 \mathrm{~J} \cdot 750$ \\
\hline Benzoic acid & 3300 & $2 / 5$ & $130 \mathrm{~J}-480 \mathrm{~J}$ \\
\hline Bis(2-ethylhexyl)phthalate & 690 & $1 / 5$ & $2300 \mathrm{~J}$ \\
\hline Butyl benzyl phthalate & 690 & $3 / 5$ & $99 \mathrm{~J}-170 \mathrm{~J}$ \\
\hline Chrysene & 690 & $1 / 5$ & $89 \mathrm{~J} \cdot 550 \mathrm{~J}$ \\
\hline Dibenzo(a,h)anthracene & 690 & $2 / 5$ & $130 \mathrm{~J}-250 \mathrm{~J}$ \\
\hline Fluoranthene & 690 & $2 / 5$ & $640 \mathrm{~J}$ \\
\hline Indeno(1,2,3-cd)pyrene & 690 & $1 / 5$ & $390 \mathrm{~J}-620 \mathrm{~J}$ \\
\hline n-Nitrosodiphenylamine & 690 & $1 / 5$ & $78 \mathrm{~J}$ \\
\hline \hline J--estimated value less than Contract Required Quantitation Limit & \\
\hline \hline
\end{tabular}

The highest concentrations of TPH, maximum concentration of $30,898 \mathrm{mg} / \mathrm{kg}$, were identified in the vicinity of the underground diesel fuel storage tanks. In general, TPH concentrations in the vadose zone soils were less than $100 \mathrm{mg} / \mathrm{kg}$. The majority of the contamination occurs in the groundwater table smear zone between 9 and 10.5 feet below ground surface.

Volatile organic compounds (including BTEX) were not detected in the subsurface soil samples above unacceptable risk levels as defined by EPA (1991a), implemented in the BLRA (U.S. Air Force 1993c), and listed in Table 8.

The source of the high concentrations of TPH is suspected to be leaks or spills of diesel fuel from the underground storage tanks. The groundwater table fluctuation is causing the floating fuel to spread throughout the smear zone near the tanks. Fuel contamination remains in the soil in the smear zone.

\subsubsection{ST18 Groundwater Contamination}

Contaminant concentrations above screening risk assessment levels (Table 8) were not detected in the groundwater samples at ST18. Benzene and toluene were not detected in any groundwater samples. Trace concentrations of xylenes $(8.0 \mu \mathrm{g} / \mathrm{L})$ were detected at one monitoring well.

Chlorinated solvents were detected at or below the Contract Required Quantitation limit during both rounds of groundwater sampling. Trichloroethane and 1,2-DCE were detected $(<2.0 \mu \mathrm{g} / \mathrm{L})$ in groundwater from all ST18 monitoring wells during the two rounds of sampling in 1991. Soil gas analyses conducted by SAIC in 1988 revealed low concentrations of halogenated hydrocarbons in the vicinity of Building 3423, approximately 500 feet south of ST18 (SAIC 1989). A drywell in this vicinity is 


\begin{tabular}{||l|c|c||}
\hline \multicolumn{4}{|c|}{ TABLE 8. Contaminant of Concern Risk-Based Cutoff Values } \\
for BTEX
\end{tabular}

suspected to be the source of this contamination. It has not been located to date and additional characterization is ongoing.

\subsubsection{ST18 Source Area Hydrology}

The vertical gradient was measured via two different methods at ST18, and it is negligible.

\subsection{Source Area ST19 (JP-4 Fuel Spill)}

Source area ST19 is located along Cargain Road next to a buried, concrete-lined utilidor that is west of the road. The utilidor contains two jet fuel pipelines (Figure 7). A snowplow broke a control valve in the late 1950 s, and approximately 200,000 gallons of JP-4 were spilled onto the surface soils along the right-of-way. Evidence of vegetative stress at the site was reported in 1982 (CH2M Hill 1982).

\subsubsection{ST19 Soil Contamination}

Very low concentrations of lead (maximum value of $17.3 \mathrm{mg} / \mathrm{kg}$ ) and TPH (maximum value of $28.4 \mathrm{mg} / \mathrm{kg}$ ) were detected in surface soils at ST19.

TPH concentrations exceeding $100 \mathrm{mg} / \mathrm{kg}$ in subsurface soil samples were located in an area along Cargain Road and extended into a narrow area to the north. The area of contamination identified to the north of Cargain Road coincided with a boggy low area. This suggests that the spill flowed into the low area.

Volatile organic compounds were detected in subsurface soil samples. Benzene was detected with the highest concentration of $0.24 \mathrm{mg} / \mathrm{kg}$. Toluene, ethylbenzene, and xylenes were detected at low concentrations in many of the soil borings within the area of TPH contamination. 


\subsubsection{ST19 Groundwater Contamination}

Benzene and toluene groundwater concentrations exceeded MCLs (Table 8) in only one well at ST19. During 1992, this well had $11 \mu \mathrm{g} / \mathrm{L}$ benzene and $1,900 \mu \mathrm{g} / \mathrm{L}$ toluene.

Evaluation of contaminant data with time indicates that the benzene concentration in this well has been decreasing monotonically since the first groundwater measurement by SAIC in 1986. Table 9 displays the annual results of BTEX groundwater analyses from the contaminated well.

\begin{tabular}{|c|c|c|c|c|c|c|}
\hline Date & 1986 & 1987 & 1988 & $\begin{array}{c}1988 \\
\text { (replicate) }\end{array}$ & 1991 & 1992 \\
\hline Benzene & 71 & NA & 35 & NA & $20 \mathrm{~J}$ & 11 \\
\hline Toluene & 1500 & 3600 & $6800 \mathrm{D}$ & 4100 & 1500 & 1900 \\
\hline Ethylbenzene & NA & 240 & 140 & $86 \mathrm{~J}$ & 390 & 610 \\
\hline Xylene & 1100 & 2500 & $3200 \mathrm{D}$ & 2800 & 2300 & 4000 \\
\hline \multicolumn{7}{|c|}{$\begin{array}{l}\text { NA--not analyzed } \\
\text { D--compound identified in an analysis at a secondary dilution factor } \\
\text { J--estimated value less than Contract Required Quantitation Limit }\end{array}$} \\
\hline
\end{tabular}

The data indicate that benzene contamination is still decreasing monotonically. However, ethylbenzene and xylene concentrations are increasing (both are still below MCLs), and the toluene concentrations are relatively stable. Toluene remains above the MCL of $1,000 \mu \mathrm{g} / \mathrm{L}$. A fate and transport modeling analysis of the data is provided in Section 5.6.4 of the RI (U.S. Air Force 1993a). The area of contaminated groundwater, where benzene exceeds its MCL, is approximately 2 acres, and it is not expected to increase.

\subsubsection{ST19 Source Area Hydrology}

Groundwater flow direction is to the north-northwest at ST19 and is consistent with the basewide groundwater flow direction. The average horizontal gradient across the area is 0.0011 foot/foot. The gradient decreases to the north-northwest. Some factors that may be affecting the gradient include local permafrost and the fill material along Cargain Road and along the pipeline corridor.

\subsection{Source Area LF05 (Old Army Landfill)}

Source area LF05, which was used from 1956 to 1959, probably received general refuse such as empty containers and drums, scrap materials, and small quantities of waste oils and spent solvents. Site investigations and analysis of groundwater, sediment, soil, and surface water indicate that concentrations of contaminants in all samples, with the exception of one groundwater sample, were below risk-based criteria. One groundwater sample contained lead four times higher than the action level of $15 \mu \mathrm{g} / \mathrm{L}$, but the analysis is considered suspect because background samples also contained lead at similar levels for the sampling event. It appears that the wells were not purged properly. This well will continue to be monitored in the site-wide groundwater monitoring program. 


\subsection{Source Area LF07 (Test Landfill)}

Source area LF07 operated for several months in 1967. It primarily received household waste with little or no industrial waste and is now covered with soil. There is no historical evidence to suggest that the landfill contains high levels of contamination. A 1991 field visit showed no evidence of stressed vegetation or surface debris. Based on its short duration of use and the probability of little or no industrial waste, there is no evidence to suggest that LF07 is a significant source of contamination.

\subsection{Source Area FT08 (Fire Training Area [past])}

Source area FT08 is an old gravel pit where fire-training exercises may have been conducted from 1948 to 1955 . The pit is filled with water and contains a partially submerged B-29 bomber fuselage. The location of this area and the fact that another area was used for fire-training activities make the use of FT08 as a fire-training area unlikely. Field investigation of groundwater, sediment, soil, and surface water indicated that no constituents were found above risk-based standards. In addition, there is no evidence to suggest that the area was ever used for fire training exercises.

\subsection{Source Area SS12 (JP-4 Fuel Spill, Building 2351)}

In 1981, 5,000 gallons of JP-4 fuel were accidentally discharged inside Building 2351. Although the majority of the spill was contained within the building, it was estimated that 100 gallons flowed outside the building onto unpaved ground. Cleanup activities recovered most of the fuel using absorbent pads.

Some contaminants would have evaporated, and the remainder would have moved through subsurface soils into the groundwater where they would have been dispersed and diluted to below regulatory levels. Moreover, any contaminants remaining in the soil at the spill area would have been removed by the grading, base-material placement, and paving that subsequently occurred around Building 2351.

There is no evidence to suggest that SS12 is a significant source of contamination.

\subsection{Source Area ST15 (Multiproduct Fuel Line)}

Two major fuel spills occurred from leaks in subsurface pipelines. In 1970, 5,000 gallons of automotive gasoline were spilled. In 1973, 5,000 gallons of JP-4 were spilled in the same location. Some contaminants would have evaporated, and the remainder would have moved through subsurface soils into the groundwater where they would have been dispersed and diluted to below regulatory levels. Site investigations were conducted in 1986 and 1987, and groundwater, sediment, soil, and surface water were all below screening criteria.

\subsection{Source Area ST16 (MOGAS Fuel Line Spill)}

In 1957, approximately 5,000 gallons of gasoline were spilled. Contamination would have likely evaporated or moved through subsurface soils into the groundwater where it would have dispersed to below regulatory levels.

In September 1986, a RCRA inspection at Building 6214 revealed approximately 265 improperly stored and labeled drums. By joint agreement among the U.S. Air Force, EPA, and ADEC, this areas is being addressed as part of the adjacent CERCLA source area ST16. The drums probably contained paint and solvents. The drums were removed and 
properly disposed through the U.S. Air Force hazardous materials program. A site inspection in August 1993 revealed small amounts of tar or asphalt deposits and several small paint spills. There was no indication of spilled solvents.

Field investigations of groundwater and soil indicate that no constituents were above screening criteria.

\subsection{Source Area ST17 (Canol Pipeline Spill)}

In the original IRP records search (CH2M Hill 1982), it was reported that the Canol pipeline ruptured in 1957 and spilled approximately 20,000 gallons of diesel fuel. Field investigations of groundwater and soil were conducted at ST17, but no fuel-related contamination was found. After further review, it appears that the 1982 report incorrectly attributed the spill to the Canol pipeline when it should have been assigned to the Haines pipeline. Therefore, based on this information and data from the field investigations, ST17 contains no source of contamination.

It appears that the actual spill area was located off base where the pipeline crosses the Richardson Highway approximately 4 miles north of ST17.

\subsection{Source Areas SD21, SD22, SD23, and SD24 (Road Oiling Sites)}

Road oiling was used for dust control on unpaved roads (SD21, SD22, SD23, and SD24) from 1950 until some time in the 1980s. Before 1978, roads were oiled with waste petroleum products, including waste oils, contaminated fuels, and solvents. From 1978 until oiling was discontinued, waste engine oils and contaminated diesel fuel were used.

Some of the volatile contaminants evaporated during application or adhered to fine-grained soil and was subsequently scattered non-uniformly over a wide area by wind, vehicle traffic, and routine road maintenance. Surface soils have been sampled in some adjacent areas and contained no contaminants of concern above screening criteria. Many of the unpaved road segments are now paved. There is no evidence to suggest that the roads are a source of continuing contamination.

\subsection{Source Area DP28 (Fly Ash Disposal Site)}

Source area DP28 is a former gravel borrow pit used for disposal of fly ash generated by the power plant from the early 1950s until 1977 . Recent analyses of the fly ash total elemental analysis and leaching tests (Extraction Procedure [EP] toxicity test and Toxic Characteristic Leach Procedure [TCLP]) indicate that the material is not a hazardous waste. In addition, fly ash constituents do not exceed risk-based criteria for soils, except for arsenic. The arsenic concentration $(5 \mathrm{mg} / \mathrm{kg}$ ) is within the Eielson AFB soil background range of 3 to $14 \mathrm{mg} / \mathrm{kg}$. Leaching tests show that the leachate would not exceed risk-based criteria. The area has been graded and is covered with vegetation.

\subsection{Source Area DP29 (Drum Burial Site)}

Source area DP29 is a former gravel pit used to dispose of 55-gallon drums from 1965 to 1968. It is estimated that 400 to 500 drums, which were thought to have contained asphalt emulsion, were placed in the gravel pit and covered with fill material. Most of the drums were empty and some may have contained only residual amounts of engine oils and industrial solvents. The gravel pit was later used for the storage of asphalt rubble. More recently, some of the buried drums have been uncovered and removed. These drums were found to be empty, crushed, and of poor integrity. 
Site investigations and analyses of groundwater, soil, surface water, and sediment showed no constituents were at concentrations above risk-based criteria.

\subsection{Source Areas SS30 and SS31 (PCB Storage Facilities)}

Source areas SS30 and SS31 are former PCB storage facilities. Material stored at SS30 and SS31 included undrained and empty transformer casings as well as PCB-contaminated liquids and soils from cleanup of a PCB spill at another location. The PCB equipment and waste material stored at SS30 and SS31 were removed between 1982 and 1987 for offbase disposal. Other waste materials such as paint, paint remover, and solvents were also stored at SS31.

In September 1986, a RCRA inspection at Building 3424 identified improperly stored and labeled waste containers. By joint agreement among the U.S. Air Force, EPA, and ADEC, this area is being addressed as part of CERCLA source area SS31.

There is no indication that SS30 and SS31 are a source of contamination based on the fact that the buildings were properly curbed and diked to prevent releases and that there is no evidence of spills inside or surrounding the buildings. The buildings are no longer used to store PCB wastes and, therefore, are not a potential source of contamination.

A nearby groundwater monitoring well, just upgradient of SS31, contained elevated levels of total organic halogens (TOX), oil and grease, and lead. While the contaminants are not attributed to SS31, this well and others in the area will be monitored to determine the source of contamination under the sitewide operable unit.

\subsection{Source Area DP40 (Power Plant Sludge Pit)}

In the initial IRP records search (CH2M Hill 1982), DP40 was reported to have been used from the late 1950s until the late 1970s to dispose of sludge from air scrubbers in the power plant and residue from periodic cleaning of the power plant boiler. More recently, it was discovered that DP40 has been active through 1993 and has received the same waste as in the past. The discharge was rerouted to the waste water treatment plant in 1993, but an National Pollutant Discharge Elimination System (NPDES) permit is in effect for the waste stream that will allow discharge to the pond, if needed. The pit is now filled with water. The water contained a chalk-like substance, probably from mineral deposits from boiler cleaning operations. The solids settle to the bottom of the pond, and in the past, these materials were dredged out of the pond approximately every 2 years and placed in the base landfill.

Analysis of the waste streams and sludge sample from the pond were supplied with the NPDES permit application in 1993. The analyses showed that waste water constituents were below risk-based criteria and the sludge contained high amounts of aluminum, iron, calcium, barium, and manganese. These five elements are commonly present in soils and aluminum, iron, and calcium are at levels found in Eielson AFB soils. Barium and manganese exceed background concentrations by 20 and 3 times, respectively. None of the concentrations exceeded screening criteria.

\subsection{Source Area SS41 (Auto Hobby Shop [past])}

Source area SS41 was used by base personnel for repairing personal vehicles from the 1960s to 1982. Drums containing used oils and fuel were stored outside the shop, and 
small quantities of industrial solvents were reportedly used. The drums were removed between 1982 and 1986. The building was demolished, and the area regraded.

Groundwater in this area contains benzene, apparently from another spill at ST13 and DP26. This contamination is addressed as part of cleanup for ST13 and DP26. Site investigations and analysis of groundwater and soil indicate that all constituents, except benzene in the groundwater, are well below screening criteria. Benzene in the groundwater will be treated as part of the ST13 and DP26 cleanup.

\subsection{Source Area SS42 (Miscellaneous Storage and Disposal Area)}

Source area SS42 was used during the 1960s for storage and disposal of miscellaneous small equipment and construction equipment. SS42 also has empty drums that contained waste oil, lubricants, and solvents. This area is now covered with trees and vegetation. Site investigations and analysis of groundwater, sediment, soil, and surface water show that only iron and manganese in groundwater exceeded screening criteria. High iron and manganese are found throughout the area, but these data are likely compromised because of inclusion of sediment particles in the water sample during collection. Background wells sampled by the same group contained similar and higher concentrations that were greatly reduced with filtration.

\subsection{Source Area SS47 (Commissary Parking Lot Fuel Spill)}

During a preconstruction soil investigation in 1987 for an addition to the Commissary, some fuel-contaminated soil was found at a depth of about 9 feet near the center of the paved parking lot. The source of contamination is unknown; there are no known or reported spills in this area. Field investigations of groundwater and soil in the center of the parking lot showed that constituents were below screening criteria. TPH was detected in soils mid-way between the ground surface and the water table at a $95 \%$ upper confidence level of $5,255 \mathrm{mg} / \mathrm{kg}$. Above and below this horizon, TPH averaged less than $100 \mathrm{mg} / \mathrm{kg}$. Lead was detected in the groundwater at two wells located on the southern, upgradient part of the parking lot, indicating the possibility of another source of contamination south of the parking lot.

\subsection{Source Area WP60 (New Auto Hobby Shop)}

Source area WP60 is used by base personnel for maintaining personal vehicles. Remodeling activities conducted in 1988 and 1990 resulted in the removal of waste disposal structures and contaminated soil. Base policies were and are in place for recycling and disposing hazardous materials. Site investigations and analysis of groundwater, sediment, soil, and surface water show that all constituents except benzo(k)fluoranthene in soils $(0.17 \mathrm{mg} / \mathrm{kg})$ were below screening criteria. The benzo(k)fluoranthene concentration corresponds to a $2 \times 10^{-6}$ carcinogenic risk for ingestion of soil under a residential scenario.

\subsection{Source Area SS62 (Garrison Slough)}

Garrison Slough, which begins at the south end of Eielson AFB, flows north through the developed portion of the base and into Moose Creek. The slough is not a domestic or industrial water supply; however, the water is used to water family garden plots and for recreational fishing. Garrison Slough was incorrectly listed as a contamination source. Though the slough may have received contamination from several different sources at the base, it is not itself a potential source of contamination. The impacts to Garrison Slough 
are being investigated whenever a source area has the potential for affecting the slough. In addition, any residual contamination in the slough will be evaluated in the ongoing sitewide investigation.

\subsection{Summary of Site Risks}

\subsection{Human Health Risks}

The baseline risk assessment (U.S. Air Force 1993c) provides the basis for taking action and indicates the exposure pathways that need to be addressed by the remedial actions. It serves as the baseline indicating what risks could exist if no action were taken the sites. This section of the ROD reports the results of the baseline risk assessment conducted for the OU2 sites.

Contamination within the SER sites was analyzed by a conservative screening risk assessment that compared the maximum concentration of each contaminant detected at the source area to a risk-based concentration calculated using a conservative target risk, calculated based on EPA standard default exposure factors assuming a residential scenario. The target risks used for this conservative screening were chosen based on the lower end of the $10^{-4}$ to $10^{-6}$ risk range specified in the NCP. The assumption used is that if no single sample exceeds a concentration representing a human health risk concern, total exposure to the contaminant from the source area will not be of concern. Specifically, the area required no further action if the maximum concentration detected was $\leq 10^{-6}$ cancer risk for water, $\leq$ $10^{-7}$ cancer risk for soil, and $\leq 0.1$ hazard quotient.

None of contamination at these sites exceeded the screening levels, thus further risk assessment was not necessary for the SER sites.

\subsubsection{Identification of Contaminants of Concern}

Data collected during the RI were used to identify contaminants of concern at each OU2 site. Media sampled included groundwater, surface water, subsurface soils, surface soils, and sediments.

The contaminants of concern were identified based on the screening method suggested in the supplemental guidance for Superfund Risk Assessments in EPA Region 10 (EPA 1991a). This method, called the "risk-based screening approach," compares the maximum concentration levels of each chemical detected at each site to a risk-based screening concentration. The screening concentrations were calculated using a future residential exposure scenario for the ingestion of soils and sediments, and the ingestion of water and inhalation of its vapors during showering.

Tables 10 through 14 list the contaminants of concern for each OU2 site, and the concentrations for each input into the risk calculations. The concentrations listed for each contaminant of concern are either the maximum value or the 95-percent upper confidence level on the mean concentration, whichever is smaller.

The analytical data used for all sites were collected during the 1991 field season, and are listed in Appendix A of the RI (U.S. Air Force 1993b). The concentrations listed in the tables in Section 5 provide a summary of these data. All water analyses and those soil and sediment analyses that met or exceeded EPA Level III were used. 


\begin{tabular}{|c|c|c|c|c|c|}
\hline $\begin{array}{l}\text { Contaminant } \\
\text { of Concern }\end{array}$ & $\begin{array}{c}\text { Surface } \\
\text { Soil } \\
(\mu \mathrm{g} / \mathrm{kg})\end{array}$ & $\begin{array}{c}\text { Subsurface } \\
\text { Soil } \\
(\mu \mathrm{g} / \mathrm{kg})\end{array}$ & $\begin{array}{l}\text { Sediment } \\
(\mu \mathrm{g} / \mathrm{kg})\end{array}$ & $\begin{array}{l}\text { Ground } \\
\text { Water } \\
(\mu \mathrm{g} / \mathrm{L})\end{array}$ & $\begin{array}{l}\text { Surface } \\
\text { Water } \\
(\mu \mathrm{g} / \mathrm{L})\end{array}$ \\
\hline \multicolumn{6}{|l|}{ Volatile Compounds } \\
\hline Benzene & & $1.30 E+03$ & & $3.84 E+02$ & $1.00 E+00$ \\
\hline Ethylbenzene & & & & $8.33 E+01$ & \\
\hline Toluene & & & & $2.03 E+03$ & \\
\hline Xylenes (total) & & & & $6.90 E+02$ & \\
\hline \multicolumn{6}{|c|}{ Semivolatile Compounds } \\
\hline Anthracene & & & & $9.00 \mathrm{E}+00$ & \\
\hline Benzo(a)anthracene & $2.60 E+02$ & $5.30 E+01$ & $4.00 E+02$ & & \\
\hline Benzo(a)pyrene & $2.90 \mathrm{E}+02$ & & $8.60 E+01$ & & \\
\hline Benzo(b)fluoranthene & $3.80 \mathrm{E}+02$ & & $3.20 \mathrm{E}+02$ & & \\
\hline Benzo(k)fluoranthene & $2.90 \mathrm{E}+02$ & $5.50 E+01$ & $2.40 \mathrm{E}+02$ & & \\
\hline Chrysene & $3.30 \mathrm{E}+02$ & $8.10 E+01$ & $6.00 E+02$ & & \\
\hline Dibenz $(a, h)$ anthracene & $9.40 E+01$ & & & & \\
\hline Indeno(1,2,3-cd)pyrene & $2.00 \mathrm{E}+02$ & & $1.10 \mathrm{E}+02$ & & \\
\hline Naphthalene & & & & $1.26 \mathrm{E}+02$ & \\
\hline Pyrene & $4.05 E+02$ & $3.90 \mathrm{E}+02$ & $1.70 \mathrm{E}+03$ & $1.00 \mathrm{E}+01$ & \\
\hline \multicolumn{6}{|l|}{ PCB } \\
\hline Aroclor -1260 & & & $1.30 E+02$ & & \\
\hline \multicolumn{6}{|l|}{ Pesticidos } \\
\hline $4,4^{\prime}-D D D$ & & & $1.50 \mathrm{E}+02$ & & \\
\hline $4,4^{\prime}-$ DDT & $1.58 \mathrm{E}+02$ & & & & \\
\hline Aldrin & $7.40 \mathrm{E}+00$ & & & & \\
\hline \multicolumn{6}{|l|}{ Metals } \\
\hline Antimony & & & & $1.34 \mathrm{E}+01$ & \\
\hline Arsenic & $1.02 E+04$ & $5.86 E+03$ & $3.73 E+04$ & $3.38 E+01$ & $6.60 E+00$ \\
\hline Barium & & & $3.81 E+05$ & $1.68 \mathrm{E}+02$ & \\
\hline Beryllium & $1.02 E+02$ & & $1.61 E+02$ & $4.60 \mathrm{E}-01$ & \\
\hline Cadmium & & & & $1.59 \mathrm{E}+00$ & \\
\hline Manganese & $3.93 E+05$ & $2.42 \mathrm{E}+05$ & $1.15 E+06$ & $2.20 E+03$ & $1.15 E+03$ \\
\hline Thallium & & & & $9.00 \mathrm{E}-01$ & \\
\hline
\end{tabular}

There are no EPA toxicity data for two of the principal contaminants at OU2 sites: TPHs and lead. Thus, these compounds were not included in the primary risk calculations. Nevertheless, the concentrations of lead present in groundwater and soil were compared to the current action levels of $15 \mu \mathrm{g} / \mathrm{L}$ for water and $400 \mathrm{mg} / \mathrm{kg}$ for soils.

\subsubsection{Exposure Assessment}

All OU2 sites are either within industrial areas of the base or are in an undeveloped area (ST19). Based on this present land use, the risk assessment used a current industrial landuse exposure scenario. Projected land-use plans for all OU2 sites are industrial (Eielson AFB 1992). Therefore, a future industrial land-use exposure scenario was calculated for each site. In these two land-use scenarios, the potentially exposed populations are current onsite workers. The current industrial scenario assumed that the current water supply 


\begin{tabular}{|c|c|c|c|}
\hline \multicolumn{4}{|c|}{$\begin{array}{c}\text { TABLE 11. Exposure Point Concentrations for ST11 Risk } \\
\text { Assessment }\end{array}$} \\
\hline $\begin{array}{l}\text { Contaminant } \\
\text { of Concern }\end{array}$ & $\begin{array}{c}\text { Surface } \\
\text { Soil } \\
(\mu \mathrm{g} / \mathrm{kg})\end{array}$ & $\begin{array}{c}\text { Subsurface } \\
\text { Soil } \\
(\mu \mathrm{g} / \mathrm{kg})\end{array}$ & $\begin{array}{l}\text { Ground } \\
\text { Water } \\
(\mu \mathrm{g} / \mathrm{L})\end{array}$ \\
\hline \multicolumn{4}{|l|}{ Volatiles } \\
\hline Benzene & & & $1.00 E+00$ \\
\hline \multicolumn{4}{|l|}{ Pesticides } \\
\hline $4,4^{\prime}$-DDT & $2.72 \mathrm{E}+02$ & & \\
\hline \multicolumn{4}{|l|}{ Metals } \\
\hline Arsenic & $1.92 E+04$ & $1.46 \mathrm{E}+04$ & $4.22 E+01$ \\
\hline Barium & & & $2.05 E+02$ \\
\hline Beryllium & $4.80 E+02$ & & \\
\hline Manganese & $6.51 E+05$ & $5.3 E+05$ & $1.98 E+03$ \\
\hline Thallium & & & $6.10 \mathrm{E}-01$ \\
\hline
\end{tabular}

system was used. The future industrial scenario assumed that water is provided by an untreated shallow groundwater well within the site.

In addition, a future residential land-use exposure scenario was calculated for each site. This scenario assumed that a small family farm, with adults and children, is located atop the site. Their water supply would be untreated groundwater from a well located within the site.

For each source area and each exposure scenario, the following exposure pathways were considered:

- ingestion of groundwater used as potable water supply

- inhalation of contaminants during groundwater use

- dermal contact with contaminants during groundwater use

- incidental ingestion of surface water

- ingestion of fish

- dermal contact with surface water

- incidental ingestion of sediments

- dermal contact with sediments

- incidental ingestion of surface soils

- dermal contact with surface soils

- ingestion of plants grown in contaminated soils

- incidental ingestion of subsurface soils

- dermal contact with subsurface soils

- inhalation of volatile contaminants released from the soil into the ambient air

- inhalation of resuspended particulates.

Tables 15 through 19 list the exposure pathways that were considered complete in the BLRA for each site and land-use scenario.

The exposure factors used for these three land-use scenarios follow, in general, EPA Region 10 guidance (Table III-1a and III-1b in EPA 1991a). Exposure factors for both "Average Exposure" and the more conservative "Reasonable Maximum Exposure" cases were used. The factors used are listed in the 22 tables in Appendix B of the BLRA (U.S. Air Force 1993c). There was some diversion from the standard default exposure factors 


\begin{tabular}{|c|c|c|c|}
\hline $\begin{array}{l}\text { Contaminant } \\
\text { of Concern }\end{array}$ & $\begin{array}{c}\text { Surface } \\
\text { Soil } \\
(\mu \mathrm{g} / \mathrm{kg})\end{array}$ & $\begin{array}{c}\text { Subsurface } \\
\text { Soil } \\
(\mu \mathrm{g} / \mathrm{kg})\end{array}$ & $\begin{array}{l}\text { Ground } \\
\text { Water } \\
(\mu \mathrm{g} / \mathrm{L})\end{array}$ \\
\hline \multicolumn{4}{|l|}{ Volatile Compounds } \\
\hline ||Benzene & & $4.05 E+03$ & $2.78 E+02$ \\
\hline Chloroform & & & $1.00 E+00$ \\
\hline Chloromethane & & & $3.00 E+00$ \\
\hline Ethylbenzene & & $1.09 E+04$ & $2.18 E+02$ \\
\hline || Toluene & & $1.96 \mathrm{E}+04$ & $8.66 \mathrm{E}+02$ \\
\hline Xylenes (total) & & & $1.42 E+03$ \\
\hline \multicolumn{4}{|c|}{ Semivolatile Compounds } \\
\hline Benzo(a)anthracene & $1.08 \mathrm{E}+03$ & $1.60 E+02$ & \\
\hline Benzo(a)pyrene & $1.25 \mathrm{E}+03$ & $8.80 E+01$ & \\
\hline Benzo(b)fluoranthene & $1.42 E+03$ & $1.20 \mathrm{E}+02$ & \\
\hline Benzo $(g, h, i)$ perylene & $7.60 \mathrm{E}+02$ & & \\
\hline Benzo(k)fluoranthene & $1.49 E+03$ & $1.00 \mathrm{E}+02$ & \\
\hline Chrysene & $1.42 E+03$ & $1.80 E+02$ & \\
\hline Dibenz(a,h)anthracene & $4.70 E+02$ & & \\
\hline Indeno(1,2,3-cd)pyrene & $8.22 E+02$ & $4.70 E+01$ & \\
\hline Naphthalene & & & $7.04 E+01$ \\
\hline Pyrene & $2.14 \mathrm{E}+03$ & $1.40 \mathrm{E}+03$ & \\
\hline \multicolumn{4}{|l|}{ Pesticides } \\
\hline $4,4^{\prime}-\mathrm{DDD}$ & $9.36 \mathrm{E}+02$ & & \\
\hline $4,4^{\prime}-\mathrm{DDE}$ & $3.24 \mathrm{E}+02$ & & \\
\hline $4,4^{\prime}-$ DDT & $5.31 \mathrm{E}+03$ & & \\
\hline \multicolumn{4}{|l|}{ Metals } \\
\hline Antimony & & & $1.28 E+01$ \\
\hline Arsenic & $1.01 E+04$ & $9.71 E+03$ & $2.67 E+01$ \\
\hline Barium & & & $2.64 E+02$ \\
\hline Beryllium & & & $8.60 E-01$ \\
\hline Cadmium & & & $1.20 E+00$ \\
\hline Manganese & $3.46 \mathrm{E}+05$ & $5.00 \mathrm{E}+05$ & $5.25 E+03$ \\
\hline Thallium & & & $1.00 E+00$ \\
\hline
\end{tabular}

resulting from site-specific characteristics. Those exposure factors that do not adhere to the guidance are described below.

The exposure duration for the average exposure scenario for industrial land is 9 years. This assessment assumed that this value should be equivalent to the average residence in a home (EPA 1991a).

Exposure duration for soils and sediments, both ingestion and dermal contact, and particulate inhalation differ from standard EPA default parameters. The values were adjusted to compensate for the sub-arctic climate at Eielson AFB. The values used (146 days for industrial and 180 days for residential) were adjusted based on the number of days in Fairbanks without snow cover. The mean number of days without snow cover at Fairbanks is 146 days; 180 days is presented as a reasonable maximum value. These 


\begin{tabular}{|c|c|c|c|}
\hline $\begin{array}{l}\text { Contaminant } \\
\text { of Concern }\end{array}$ & $\begin{array}{c}\text { Surface } \\
\text { Soil } \\
(\mu \mathrm{g} / \mathrm{kg})\end{array}$ & $\begin{array}{c}\text { Subsurface } \\
\text { Soil } \\
(\mu \mathrm{g} / \mathrm{kg})\end{array}$ & $\begin{array}{l}\text { Ground } \\
\text { Water } \\
(\mu g / L)\end{array}$ \\
\hline \multicolumn{4}{|l|}{ Volatile Compounds } \\
\hline Chlor oform & & & $2.00 E+00$ \\
\hline Trichloroethene & & & $2.00 \mathrm{E}+00$ \\
\hline \multicolumn{4}{|l|}{ Semivolatile Compounds } \\
\hline Benzo(a)anthracene & $4.00 \mathrm{E}+02$ & & \\
\hline Benzo(a)pyrene & $4.82 E+02$ & & \\
\hline Benzo(b)fluoranthene & $4.48 E+02$ & & \\
\hline Benzo $(\mathrm{g}, \mathrm{h}, \mathrm{i})$ perylene & $6.10 E+02$ & & \\
\hline Benzo(k)fluoranthene & $4.49 \mathrm{E}+02$ & & \\
\hline Chrysene & $4.91 E+02$ & & \\
\hline Dibenz(a,h)anthracene & $9.40 \mathrm{E}+01$ & & \\
\hline Indeno(1,2,3-cd)pyrene & $5.23 E+02$ & & \\
\hline N-nitrosodiphenylamine (1) & & & $3.00 \mathrm{E}+00$ \\
\hline Pyrene & $5.80 \mathrm{E}+02$ & & \\
\hline \multicolumn{4}{|l|}{ Metals } \\
\hline Arsenic & $1.20 E+04$ & $3.70 \mathrm{E}+03$ & $4.30 E+01$ \\
\hline Beryllium & $4.66 \mathrm{E}+02$ & & \\
\hline Cadmium & & & $5.52 E+00$ \\
\hline Manganese & $5.11 E+05$ & $3.40 E+05$ & $1.63 E+03$ \\
\hline Thallium & & & $1.20 E+00$ \\
\hline
\end{tabular}

values were initially advanced in Appendix A of the Management Plan for OUs 3, 4, and 5 (Battelle 1992). The effect of adjustment is discussed in the uncertainty sections for each site.

There are no known subsistence or sport fisheries at Eielson AFB, and the exposure factors for the fish ingestion pathway reflect this (Appendix B of U.S. Air Force 1993c). The limited size and depth of the surface water bodies (Hardfill Lake and Garrison Slough) should preclude these subgroups in the future.

The input concentrations for groundwater BTEX for future scenarios at ST19 are derived from fate and transport modeling using the Multimedia Environmental Pollutant Assessment System (MEPAS). The primary focus was to model future concentrations of contaminants in groundwater (BTEX) that would be transported through the leachate pathway from soil contamination present today. The results indicated that benzene and toluene concentrations have been and will continue to decrease. In addition, the area of groundwater contamination is limited to approximately 2 acres. Ethylbenzene and xylene concentrations will increase. Modeling results indicate that benzene and toluene concentrations should eventually reach values near their MCLs. The modeled peak concentration for ethylbenzene may exceed its MCL; xylene should not exceed its MCL.

Some of the assumptions associated with modeling assessment are as follows:

- Each component in the BTEX waste can be modeled as a separate and independent constituent. 


\begin{tabular}{||l|c|c|c||}
\hline \multicolumn{1}{||c|}{$\begin{array}{c}\text { TABLE 14. Exposure Point Concentrations for ST19 Risk Assessment } \\
\text { Of Concern }\end{array}$} & $\begin{array}{c}\text { Surface } \\
\text { Soil } \\
(\mu \mathrm{g} / \mathrm{kg})\end{array}$ & $\begin{array}{c}\text { Subsurface } \\
\text { Soil } \\
(\mu \mathrm{g} / \mathrm{kg})\end{array}$ & $\begin{array}{c}\text { Ground } \\
\text { Water } \\
(\mu \mathrm{g} / \mathrm{L})\end{array}$ \\
\hline \hline Volatile Compounds & & & $8.50 \mathrm{E}+00$ \\
\hline Benzene & & & $2.50 \mathrm{E}+02$ \\
\hline Ethylbenzene & & & $9.40 \mathrm{E}+02$ \\
\hline Toluene & & & $1.46 \mathrm{E}+03$ \\
\hline Xylenes (total) & & $5.20 \mathrm{E}+01$ & \\
\hline Semivolatile Compounds & $1.67 \mathrm{E}+02$ & \\
\hline Benzo(a)anthracene & & $4.50 \mathrm{E}+02$ & \\
\hline Chrysene & & & $2.59 \mathrm{E}+01$ \\
\hline Pyrene & & $4.10 \mathrm{E}+03$ & $4.00 \mathrm{E}+01$ \\
\hline Metals & $1.94 \mathrm{E}+04$ & & $2.20 \mathrm{E}+02$ \\
\hline Antimony & & & $3.10 \mathrm{E}-01$ \\
\hline Arsenic & $3.40 \mathrm{E}+02$ & & $2.10 \mathrm{E}+00$ \\
\hline Barium & & & $7.40 \mathrm{E}+03$ \\
\hline Beryllium & $6.57 \mathrm{E}+05$ & $1.7 \mathrm{E}+05$ & $8.00 \mathrm{E}-01$ \\
\hline Cadmium & & & \\
\hline Manganese & & & \\
\hline Thallium & & & \\
\hline
\end{tabular}

- Parameters that are typically used in calibrating models with the same level of detail as MEPAS include distribution coefficients, pore-water velocities, and mass-flux rates from the source. These parameters are generally not well known and can be modified to ensure that the model can predict the arrival of a contaminant at a monitoring well at a given concentration level. Although different combinations of the parameters result in similar consequences, many of those combinations result in unrealistic values for some of the parameters. By using realistic values for these parameters, the calibration process at least ensures that the concentrations predicted by the model are the right order of magnitude and representative of the problem at hand.

- In many of the simulations, the zone of mixing is assumed to be 10 feet. Limiting the depth over which the mixing occurs attempts to account for the lower densities $(\approx 0.88$ $\mathrm{g} / \mathrm{cm}^{3}$ ) associated with the light nonaqueous phase liquids (LNAPLs) in the BTEX constituents.

- Monitored data containing time-varying, groundwater concentrations were available at ST19 (Table 9). This information was utilized to calibrate the model used in the preliminary transport and fate analysis for recreating the initial contamination of groundwater at the site.

A more detailed description of the models used is in Section 8.3 and Appendix $C$ of the BLRA (U.S. Air Force 1993c).

\subsubsection{Toxicity Assessment}

The values and references for all toxicity data used in the risk assessment are given in Table 9.1 of the BLRA (U.S. Air Force 1993c). Table 20 is an abbreviated listing of the 


\begin{tabular}{|c|c|c|c|}
\hline Theoretical Pathways & $\begin{array}{c}\text { Current Land-Use } \\
\text { Industrial }\end{array}$ & $\begin{array}{c}\text { Future } \\
\text { Residential }\end{array}$ & $\begin{array}{l}\text { Land-Use } \\
\text { Industrial }\end{array}$ \\
\hline Ingestion of groundwater used as potable water supply & $\mathrm{x}$ & $\mathbf{x}$ & $\mathrm{x}$ \\
\hline Inhalation of and dermal contact with contaminants during groundwater use & $\bar{x}$ & $\bar{x}$ & $\mathrm{x}$ \\
\hline Incidental ingestion of surface water & $\underline{x}$ & $\bar{x}$ & $\underline{x}$ \\
\hline Dermal contact with surface water & $\bar{x}$ & $\bar{x}$ & $\bar{x}$ \\
\hline Ingestion of fish from Hardfill Lake & $\mathrm{x}$ & $\mathrm{x}$ & $\underline{x}$ \\
\hline Incidental ingestion of surface soils & $\mathrm{x}$ & $\mathbf{x}$ & $\mathbf{x}$ \\
\hline Dermal contact with surface soils & $\mathbf{x}$ & $\mathbf{x}$ & $\underline{x}$ \\
\hline Ingestion of plants grown in contaminated soils & $\cdot$ & $\underline{x}$ & - \\
\hline Incidental ingestion of subsurface soils & $\bar{x}$ & $\bar{x}$ & $\underline{x}$ \\
\hline Dermal contact with subsurface soils & $\mathbf{x}$ & $\mathbf{x}$ & $\mathbf{x}$ \\
\hline Inhalation of volatile contaminants released from the soil into the ambient air & $\bar{x}$ & $\mathbf{x}$ & $\underline{x}$ \\
\hline Inhalation of resuspended particulates & $\bar{x}$ & $\bar{x}$ & $\mathrm{X}$ \\
\hline
\end{tabular}

\begin{tabular}{|c|c|c|c|}
\hline Theoretical Pathways & $\begin{array}{c}\text { Current Land-Use } \\
\text { Industrial }\end{array}$ & $\begin{array}{c}\text { Future } \\
\text { Residential }\end{array}$ & $\begin{array}{l}\text { Land-Use } \\
\text { Industrial }\end{array}$ \\
\hline Ingestion of groundwater used as potable water supply & - & $\mathbf{x}$ & $\mathrm{x}$ \\
\hline Inhalation of and dermal contact with contaminants during groundwater use & - & $\mathbf{x}$ & $\bar{x}$ \\
\hline Incidental ingestion of surface water & $\bar{x}$ & $\bar{x}$ & $\mathbf{x}$ \\
\hline Ingestion of fish from Garrison Slough & $\bar{x}$ & $\mathrm{x}$ & $\bar{x}$ \\
\hline Incidental ingestion of surface soils & $\mathbf{x}$ & $\mathrm{x}$ & $\mathrm{x}$ \\
\hline Dermal contact with surface soils & $\bar{x}$ & $\underline{x}$ & $\bar{x}$ \\
\hline Ingestion of plants grown in contaminated soils & - & $\mathbf{x}$ & - \\
\hline Incidental ingestion of subsurface soils & $\bar{x}$ & $\underline{x}$ & $\mathrm{x}$ \\
\hline Dermal contact with subsurface soils & $\underline{x}$ & $\bar{x}$ & $\bar{x}$ \\
\hline Inhalation of volatile contaminants released from the soil into the ambient air & $\bar{x}$ & $\bar{x}$ & $\bar{x}$ \\
\hline Inhalation of resuspended particulates & $\mathrm{x}$ & $\mathbf{x}$ & $\mathrm{x}$ \\
\hline
\end{tabular}


TABLE 17. Summary of Human Exposure Pathways for ST13 and DP26

\begin{tabular}{|c|c|c|c|}
\hline Theoretical Pathways & $\begin{array}{c}\text { Current Land-Use } \\
\text { Industrial }\end{array}$ & $\begin{array}{c}\text { Future } \\
\text { Residential }\end{array}$ & $\begin{array}{l}\text { Land-Use } \\
\text { Industrial }\end{array}$ \\
\hline Ingestion of groundwater used as potable water supply & - & $\mathbf{x}$ & $\mathrm{X}$ \\
\hline Inhalation of and dermal contact with contaminants during groundwater use & - & $\mathbf{x}$ & $\mathrm{x}$ \\
\hline Incidental ingestion of surface soils & $\mathbf{x}$ & $\mathbf{x}$ & $\mathrm{x}$ \\
\hline Dermal contact with surface soils & $\mathbf{x}$ & $\mathrm{x}$ & $\mathrm{X}$ \\
\hline Ingestion of plants grown in contaminated soils & - & $\mathrm{x}$ & - \\
\hline Incidental ingestion of subsurface soils & $\bar{x}$ & $\mathbf{X}$ & $\mathrm{X}$ \\
\hline Dermal contact with subsurface soils & $\bar{x}$ & $\bar{x}$ & $\mathrm{x}$ \\
\hline Inhalation of volatile contaminants released from the soil into the ambient air & $\bar{x}$ & $\mathbf{x}$ & $\mathrm{X}$ \\
\hline Inhalation of resuspended particulates & $\mathbf{x}$ & $\mathrm{x}$ & $\mathrm{x}$ \\
\hline
\end{tabular}

\section{TABLE 18. Summary of Human Exposure Pathways for ST18}

\begin{tabular}{|c|c|c|c|}
\hline Theoretical Pathways & $\begin{array}{c}\text { Current Land-Use } \\
\text { Industrial }\end{array}$ & $\begin{array}{c}\text { Future } \\
\text { Residential }\end{array}$ & $\begin{array}{l}\text { Land-Use } \\
\text { Industrial }\end{array}$ \\
\hline Ingestion of groundwater used as potable water supply & - & $\mathbf{x}$ & $\mathbf{x}$ \\
\hline Inhalation of and dermal contact with contaminants during groundwater use & - & $\bar{x}$ & $\bar{x}$ \\
\hline Incidental ingestion of surface soils & $\mathrm{X}$ & $\mathrm{X}$ & $\mathrm{X}$ \\
\hline Dermal contact with surface soils & $\bar{x}$ & $\mathrm{X}$ & $\underline{x}$ \\
\hline Ingestion of plants grown in contaminated soils & - & $\bar{x}$ & - \\
\hline Incidental ingestion of subsurface soils & $\bar{X}$ & $\bar{x}$ & $\mathbf{x}$ \\
\hline Dermal contact with subsurface soils & $\bar{x}$ & $\bar{x}$ & $\mathbf{x}$ \\
\hline Inhalation of volatile contaminants released from the soil into the ambient air & $\bar{x}$ & $\bar{x}$ & $\bar{x}$ \\
\hline Inhalation of resuspended particulates & $\mathrm{x}$ & $\bar{x}$ & $\mathrm{x}$ \\
\hline
\end{tabular}




\begin{tabular}{|c|c|c|c|}
\hline Theoretical Pathways & $\begin{array}{c}\text { Current Land-Use } \\
\text { Industrial }\end{array}$ & $\begin{array}{r}\text { Future } \\
\text { Residential }\end{array}$ & $\begin{array}{l}\text { Land-Use } \\
\text { Industrial }\end{array}$ \\
\hline Ingestion of groundwater used as potable water supply & - & $\mathbf{x}$ & $\mathbf{x}$ \\
\hline Inhalation of and dermal contact with contaminants during groundwater use & - & $\mathbf{x}$ & $\mathbf{x}$ \\
\hline Incidental ingestion of surface soils & $\mathrm{x}$ & $x$ & $\mathbf{x}$ \\
\hline Dermal contact with surface soils & $\mathbf{x}$ & $\bar{x}$ & $\mathbf{x}$ \\
\hline Ingestion of plants grown in contaminated soils & - & $\mathrm{x}$ & - \\
\hline Incidental ingestion of subsurface soils & $\bar{x}$ & $\bar{x}$ & $\mathrm{x}$ \\
\hline Dermal contact with subsurface soils & $\mathbf{x}$ & $\mathbf{x}$ & $\mathbf{x}$ \\
\hline Inhalation of volatile contaminants released from the soil into the ambient air & $\mathbf{X}$ & $\mathbf{x}$ & $\mathbf{x}$ \\
\hline Inhalation of resuspended particulates & $\mathbf{X}$ & $\mathbf{x}$ & $\mathbf{X}$ \\
\hline
\end{tabular}




\begin{tabular}{|c|c|c|c|c|c|c|c|c|}
\hline \multirow[b]{2}{*}{ Analyte } & \multicolumn{8}{|c|}{ IABLE 20. Toxicity Data Used for Risk Assessments } \\
\hline & $\begin{array}{c}(\mathrm{mg} / \mathrm{kg} \cdot \mathrm{d})-1 \\
\text { Oral }\end{array}$ & Reference & $\begin{array}{c}(\mathrm{mg} / \mathrm{kg} \cdot \mathrm{d})-1 \\
\text { Inhalation }\end{array}$ & Reference & $\begin{array}{c}(\mathrm{mg} / \mathrm{kg} \cdot \mathrm{d}) \\
\text { Oral }\end{array}$ & Reference & $\begin{array}{l}(\mathrm{mg} / \mathrm{kg} \cdot \mathrm{d}) \\
\text { Inhalation }\end{array}$ & Reference \\
\hline \multicolumn{9}{|l|}{ Volatile Compounds } \\
\hline Benzene & $2.90 \mathrm{E}-02$ & 5 & $2.905-02$ & 5 & & & & \\
\hline Chloroform & $6.10 \mathrm{E}-03$ & 5 & $8.10 \mathrm{E}-02$ & 5 & $1.00 \mathrm{E}-02$ & 5 & & \\
\hline Chloromethane & $1.30 \mathrm{E}-02$ & 3 & $6.30 \mathrm{E}-03$ & 3 & $5.40 \mathrm{E}-01$ & 2 & & \\
\hline Ethylbenzene & & & & & $1.00 \mathrm{E}-01$ & 5 & $2.86 \mathrm{E}-01$ & 5 \\
\hline Toluene & & & & & $2.00 \mathrm{E}-01$ & 5 & $5.70 \mathrm{E}-01$ & 5 \\
\hline Trichloroethene & $1.10 \mathrm{E}-02$ & 7 & $1.70 \mathrm{E}-02$ & 3 & & & & \\
\hline Xylenes (total) & & & & & $2.00 \mathrm{E}+00$ & 5 & $8.60 \mathrm{E}-02$ & 3 \\
\hline \multicolumn{9}{|l|}{ Semivolatile Compounds } \\
\hline Anthracene & $2.34 \mathrm{E}+00$ & 1 & $1.95 \mathrm{E}+00$ & 1 & $3.00 \mathrm{E}-01$ & 5 & & \\
\hline Benzo(a)anthracene & $1.06 \mathrm{E}+00$ & 1 & $8.85 E-01$ & 1 & & & & \\
\hline Benzo(a)pyrene & $7.30 E+00$ & 5 & $6.10 E+00$ & 5 & & & & \\
\hline Benzo(b)fluoranthene & $1.02 E+00$ & 1 & $8.54 \mathrm{E}-01$ & 1 & & & & \\
\hline Benzo $(\mathrm{g}, \mathrm{h}, \mathrm{i})$ perylene & $1.61 \mathrm{E}-01$ & 1 & $1.34 \mathrm{E}-01$ & 1 & & & & \\
\hline Benzo(k)fluoranthene & $4.82 \mathrm{E}-01$ & 1 & $4.03 E-01$ & $\overline{1}$ & & & & \\
\hline Chrysene & $3.21 \mathrm{E}-02$ & 1 & $2.68 \mathrm{E}-02$ & 1 & & & & \\
\hline Dibenz(a,h)anthracene & $8.10 E+00$ & 1 & $6.77 \mathrm{E}+00$ & 1 & & & & \\
\hline Indeno(1,2,3-cd)pyrene & $1.69 \mathrm{E}+00$ & 1 & $1.42 \mathrm{E}+00$ & 1 & & & & \\
\hline $\mathrm{N}$-nitrosodiphenylamine (1) & $4.90 \mathrm{E}-03$ & 5 & & & & & & \\
\hline Naphthalene & & & & & $4.00 \mathrm{E}-02$ & 4 & $4.00 \mathrm{E}-03$ & 4 \\
\hline Pyrene & $5.91 \mathrm{E}-01$ & 1 & $4.94 \mathrm{E}-01$ & 1 & $3.00 E-02$ & 5 & & \\
\hline \multicolumn{9}{|l|}{ PCB } \\
\hline Aroclor-1260 & $7.70 E+00$ & 6 & $7.70 \mathrm{E}+00$ & 6 & & & & \\
\hline \multicolumn{9}{|l|}{ Pesticides } \\
\hline $4,4^{\prime}$-DDD & $2.40 \mathrm{E}-01$ & 5 & $2.50 E-01$ & 5 & & & & \\
\hline $4,4^{\prime}-\mathrm{DDE}$ & $3.40 \mathrm{E}-01$ & 5 & & & & & & \\
\hline $4,4^{\prime}$-DDT & $3.40 \mathrm{E}-01$ & 5 & $3.40 \mathrm{E}-01$ & 5 & $5.00 \mathrm{E}-04$ & 5 & & \\
\hline Aldrin & $1.70 \mathrm{E}+01$ & 5 & $1.70 \mathrm{E}+01$ & 5 & $3.00 \mathrm{E}-05$ & 5 & & \\
\hline \multicolumn{9}{|l|}{ Metals } \\
\hline Antimony & & & & & $4.00 \mathrm{E}-04$ & 5 & & \\
\hline Arsenic & $1.75 \mathrm{E}+00$ & 4 & $1.20 E+01$ & 5 & $3.00 E-04$ & 5 & & \\
\hline Barium & & & & & $7.00 \mathrm{E}-02$ & 5 & $1.00 \mathrm{E}-04$ & 3 \\
\hline
\end{tabular}




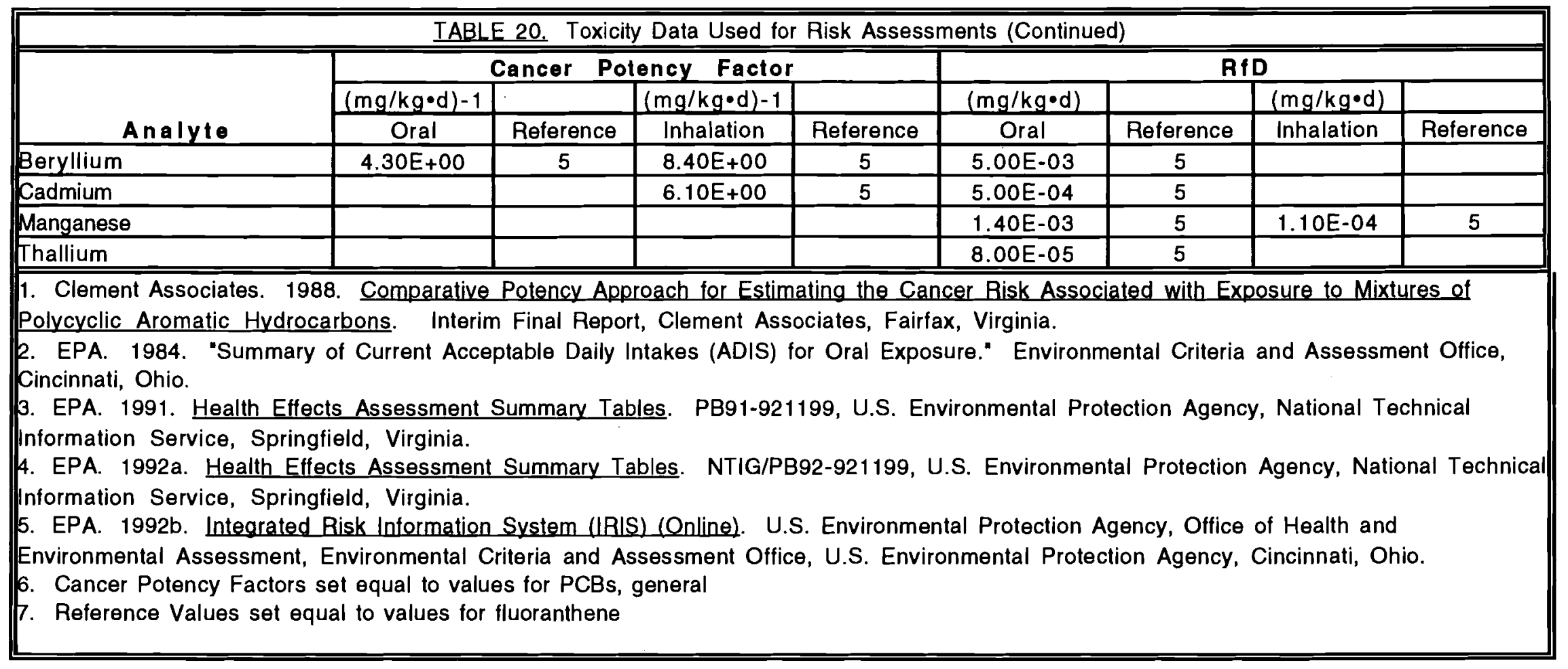


toxicity data for the contaminants of concern only. Toxicity data are divided into carcinogenic (slope factors [SFs]) and noncarcinogenic (reference dosages [RfDs]).

SFs have been developed by EPA's Carcinogenic Assessment Group for estimating excess lifetime cancer risks associated with exposure to potentially carcinogenic contaminants of concern. SFs, which are expressed in units of (mg/kg-day $)^{-1}$, are multiplied by the estimated intake of a potential carcinogen, in $\mathrm{mg} / \mathrm{kg}$-day, to provide an upper-bound estimate of the excess lifetime cancer risk associated with exposure at that intake level. The term "upper bound" reflects the conservative estimate of the risks calculated from the SF. Use of this approach makes underestimation of the actual cancer risk highly unlikely. SFs are derived from the results of human epidemiological studies or chronic animal bioassays to which animal-to-human extrapolation and uncertainty factors have been applied (e.g., to account for the use of animal data to predict effects on humans).

RfDs have been developed by EPA to indicate the potential for adverse health effects from exposure to contaminants of concern exhibiting noncarcinogenic effects. RfDs, which are expressed in units of $\mathrm{mg} / \mathrm{kg}$-day, are estimates of lifetime daily exposure levels for humans, including sensitive individuals. Estimated intakes of contaminants of concern from environmental media (e.g., the amount of a contaminant of concern ingested from contaminated drinking water) can be compared to the RfD. RfDs are derived from human epidemiological studies or animal studies to which uncertainty factors have been applied (e.g., to account for the use of animal data to predict effects on humans).

No EPA toxicity data exist for two of the principal contaminants at OU2 sites: TPHs and lead. Thus, these compounds were not included in the primary risk calculations. The TPH-rich contamination encountered at OU2 is believed to have resulted from past spills and leaks of fuels. Because of the variability of fuel degradation in soil, no toxicity value exists. Nevertheless, the sample with the highest TPH concentration at each site also had a comprehensive analysis of volatile and semivolatile organic compounds. Lead concentrations in groundwater and soils were compared to EPA guidance for soils $(500 \mathrm{mg} / \mathrm{kg})$ and a groundwater action level of $15 \mu \mathrm{g} / \mathrm{L}$. Maximum total lead groundwater concentrations at ST10, SS14, ST13, and DP26 exceed this action level.

\subsubsection{Risk Characterization (current and future)}

The exposure point concentrations listed in Appendix F of the BLRA (U.S. Air Force 1993c) for each site were used with the toxicity data in Table 20 to calculate the risks for carcinogens and noncarcinogens at each of the OU2 sites.

For carcinogens, risks were estimated as the incremental probability of an individual developing cancer over a lifetime as a result of exposure to the carcinogen. Excess lifetime cancer risk was calculated from the following equation:

$$
\text { Risk }=\text { CDI } \times \text { SF }
$$

where:

Risk $=$ a unitless probability (e.g., $2 \times 10^{-5}$ ) of an individual developing cancer

$\mathrm{CDI}=$ chronic daily intake average over 70 years $(\mathrm{mg} / \mathrm{kg}$-day)

$\mathrm{SF}=$ slope factor $(\mathrm{mg} / \mathrm{kg} \text {-day })^{-1}$ 
These risks are probabilities that are generally expressed in scientific notation (e.g., $1 \times 10^{-6}$ or $1 \mathrm{E}-6$ ). An excess lifetime cancer risk of $1 \times 10^{-6}$ indicates that, as a reasonable maximum estimate, an individual has a 1 in 1,000,000 chance of developing cancer as a result of site-related exposure to a carcinogen over a 70-year lifetime under the specific exposure conditions at a site.

For noncarcinogens, the potential effects were evaluated by comparing an exposure level over a specified time period (e.g., lifetime) with a reference dose derived for a similar exposure period. The ratio of exposure to toxicity is called a hazard quotient (HQ). By adding the HQs for all contaminants of concern within a medium or across all media to which a given population may reasonably be exposed, the Hazard Index (HI) can be generated.

The HQ is calculated as follows:

\section{Noncancer $\mathrm{HQ}=\mathrm{CDI} / \mathrm{RfD}$}

where:

$\mathrm{CDI}=$ chronic daily intake

$\mathrm{RfD}=$ reference dose

CDI and RfD are expressed in the same units and represent the same exposure period (i.e., chronic, subchronic, or short term).

Risk calculations were made for each of the three land-use scenarios, all associated exposure pathways, and for two different exposure cases--"average exposure" and "reasonable maximum exposure."

Tables 21 through 25 summarize by site the risk calculation results. Each table lists the cancer risk and the $\mathrm{HI}$ for each exposure pathway individually. The values presented are for the "reasonable maximum exposure case" only. A total cancer risk value and a total HI are presented that add all of the exposure pathway risks together.

The risk values presented exclude the contribution from potential background metals. Some areas of Fairbanks, Alaska, are noted for elevated concentrations of metals, in particular iron, manganese, and arsenic in the groundwater (Cederstrom 1963; Nelson 1978; Krumhart 1982; Weddleton et al. 1989). These metals and several others including antimony, barium, beryllium, cadmium, and thallium were found to occur at elevated concentrations at OU2. Many of these metals exceed risk-based screening concentrations, and background samples for both soil and groundwater were collected to help identify which metals could be considered equivalent to site background and not the result of base activities. U.S. Air Force (1993e, f) has documented the results of the Eielson AFB sitewide background sampling efforts.

The metals at OU2 sites were statistically compared to site background in section E.1 of the BLRA (U.S. Air Force 1993c). The metals that could not be considered statistically equivalent to background were compared to concentrations of metals believed to be background (i.e., iron) in Section E.2. This additional step was necessary, in part, because the background groundwater samples were collected in June when groundwater is diluted with snow melt. OU2 groundwater samples were collected during August and September when dilution is minimal. No background data exist for several metals. One of these, thallium, occurs in concentrations that exceed risk-based screening concentrations. 
TABLE 21. Summary of Cancer Risk and Hazard Index for the Reasonable Maximum Exposure Case at ST10/SS14

\begin{tabular}{|c|c|c|c|c|c|c|}
\hline \multirow[b]{3}{*}{ Exposure Pathway } & \multicolumn{6}{|c|}{ Land-Use Scenario } \\
\hline & Current & Industrial & Future & Industrial & Future & Residential \\
\hline & $\begin{array}{c}\text { Cancer } \\
\text { Risk }\end{array}$ & $\begin{array}{l}\text { Hazard } \\
\text { Index }\end{array}$ & $\begin{array}{c}\text { Cancer } \\
\text { Risk }\end{array}$ & $\begin{array}{l}\text { Hazard } \\
\text { Index }\end{array}$ & $\begin{array}{c}\text { Cancer } \\
\text { Risk }\end{array}$ & $\begin{array}{l}\text { Hazard } \\
\text { Index }\end{array}$ \\
\hline Ingestion of groundwater & $6 \times 10^{-5}$ & 0.1 & $6 \times 10^{-5}$ & 0.01 & $2 \times 10^{-4}$ & 0.4 \\
\hline Inhalation/dermal contact groundwater use & $9 \times 10^{-4}$ & 2 & $9 \times 10^{-4}$ & 2 & $2 \times 10^{-3}$ & 3 \\
\hline Incidental ingestion of sediments & $4 \times 10^{-7}$ & $<0.01$ & $4 \times 10^{-7}$ & $<0.01$ & $3 \times 10^{-6}$ & $<0.01$ \\
\hline Ingestion of plants grown in contaminated soils & NA & NA & NA & NA & $8 \times 10^{-6}$ & $<0.01$ \\
\hline Incidental ingestion of surface soils & $5 \times 10^{-7}$ & $<0.01$ & $5 \times 10^{-7}$ & $<0.01$ & $4 \times 10^{-6}$ & $<0.01$ \\
\hline Dermal contact with surface soils & $5 \times 10^{-7}$ & $<0.01$ & $5 \times 10^{-7}$ & $<0.01$ & $1 \times 10^{-6}$ & $<0.01$ \\
\hline Incidental ingestion of subsurface soils & $<1 \times 10^{-7}$ & $<0.01$ & $<1 \times 10^{-7}$ & $<0.01$ & $3 \times 10^{-7}$ & $<0.01$ \\
\hline Inhalation of volatile compounds from soils & $1 \times 10^{-6}$ & $<0.01$ & $1 \times 10^{-6}$ & $<0.01$ & $1 \times 10^{-6}$ & $<0.01$ \\
\hline Summation for all exposure pathways & $1 \times 10^{-3}$ & 2 & $1 \times 10^{-3}$ & 2 & $2 \times 10^{-3}$ & 4 \\
\hline
\end{tabular}

IABLE 22. Summary of Cancer Risk and Hazard Index for the Reasonable Maximum Exposure Case at ST11

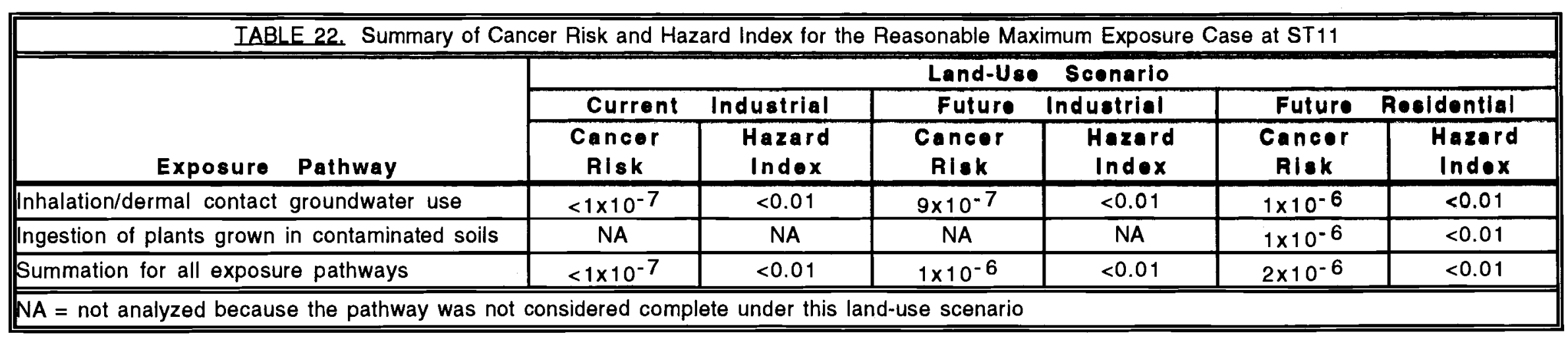




\begin{tabular}{|c|c|c|c|c|c|c|}
\hline \multirow[b]{3}{*}{ Exposure Pathway } & \multicolumn{6}{|c|}{ Land-Use Scenario } \\
\hline & Current & Industrial & Future & Industrial & Future & Residential \\
\hline & $\begin{array}{c}\text { Cancer } \\
\text { Risk }\end{array}$ & $\begin{array}{l}\text { Hazard } \\
\text { Index }\end{array}$ & $\begin{array}{c}\text { Cancer } \\
\text { Risk }\end{array}$ & $\begin{array}{l}\text { Hazard } \\
\text { Index }\end{array}$ & $\begin{array}{c}\text { Cancer } \\
\text { Risk }\end{array}$ & $\begin{array}{l}\text { Hazard } \\
\text { Index }\end{array}$ \\
\hline Ingestion of groundwater & NA & NA & $3 \times 10^{-5}$ & 0.09 & $1 \times 10^{-4}$ & 0.2 \\
\hline Inhalation/dermal contact groundwater use & NA & NA & $3 \times 10^{-4}$ & 2 & $4 \times 10^{-4}$ & 3 \\
\hline Ingestion of plants grown in contaminated soils & NA & NA & NA & NA & $3 \times 10^{-5}$ & 0.03 \\
\hline Incidental ingestion of surface soils & $2 \times 10^{-6}$ & $<0.01$ & $2 \times 10^{-6}$ & $<0.01$ & $2 \times 10^{-5}$ & 0.02 \\
\hline Dermal contact with surface soils & $2 \times 10^{-6}$ & $<0.01$ & $2 \times 10^{-6}$ & $<0.01$ & $5 \times 10^{-6}$ & $<0.01$ \\
\hline Incidental ingestion of subsurface soils & $1 \times 10^{-7}$ & $<0.01$ & $<1 \times 10^{-7}$ & $<0.01$ & $1 \times 10^{-6}$ & $<0.01$ \\
\hline Dermal contact with subsurface soils & $1 \times 10^{-7}$ & $<0.01$ & $<1 \times 10^{-7}$ & $<0.01$ & $3 \times 10^{-7}$ & $<0.01$ \\
\hline Inhalation of volatile compounds from soils & $1 \times 10^{-6}$ & $<0.01$ & $1 \times 10^{-6}$ & $<0.01$ & $2 \times 10^{-6}$ & $<0.01$ \\
\hline Summation for all exposure pathways & $1 \times 10^{-5}$ & 0.01 & $3 \times 10^{-4}$ & 2 & $6 \times 10^{-4}$ & 3 \\
\hline
\end{tabular}

\begin{tabular}{|c|c|c|c|c|c|c|}
\hline \multirow[b]{3}{*}{ Exposure Pathway } & \multicolumn{6}{|c|}{ Land-Use Scenario } \\
\hline & Current & Industrial & Future & Industrial & Future & Residential \\
\hline & $\begin{array}{c}\text { Cancer } \\
\text { Risk } \\
\end{array}$ & $\begin{array}{l}\text { Hazard } \\
\text { Index }\end{array}$ & $\begin{array}{c}\text { Cancer } \\
\text { Risk }\end{array}$ & $\begin{array}{l}\text { Hazard } \\
\text { Index }\end{array}$ & $\begin{array}{c}\text { Cancor } \\
\text { Risk }\end{array}$ & $\begin{array}{l}\text { Hazard } \\
\text { Index }\end{array}$ \\
\hline Ingestion of groundwater & NA & NA & $<1 \times 10^{-7}$ & $<0.01$ & $6 \times 10^{-7}$ & $<0.01$ \\
\hline Inhalation/dermal contact groundwater use & NA & NA & $5 \times 10^{-6}$ & $<0.01$ & $9 \times 10^{-6}$ & $<0.01$ \\
\hline Dermal contact with surface soils & $7 \times 10^{-7}$ & $<0.01$ & $4 \times 10^{-7}$ & $<0.01$ & $2 \times 10^{-6}$ & $<0.01$ \\
\hline Inhalation of volatile compounds from soils & $<1 \times 10^{-7}$ & $<0.01$ & $<1 \times 10^{-7}$ & $<0.01$ & $5 \times 10^{-7}$ & $<0.01$ \\
\hline Summation for all exposure pathways & $1 \times 10^{-6}$ & $<0.01$ & $7 \times 10^{-6}$ & $<0.01$ & $3 \times 10^{-5}$ & $<0.01$ \\
\hline
\end{tabular}




\begin{tabular}{|c|c|c|c|c|c|c|}
\hline \multirow[b]{3}{*}{ Exposure Pathway } & \multicolumn{6}{|c|}{ Land-Use Scenario } \\
\hline & Current & Industrial & Future & Industrial & Future & Residential \\
\hline & $\begin{array}{c}\text { Cancer } \\
\text { Risk }\end{array}$ & $\begin{array}{l}\text { Hazard } \\
\text { Index }\end{array}$ & $\begin{array}{c}\text { Cancer } \\
\text { Risk }\end{array}$ & $\begin{array}{l}\text { Hazard } \\
\text { Index }\end{array}$ & $\begin{array}{c}\text { Cancer } \\
\text { Risk }\end{array}$ & $\begin{array}{l}\text { Hazard } \\
\text { Index }\end{array}$ \\
\hline Ingestion of groundwater & NA & NA & $9 \times 10^{-7}$ & 0.02 & $3 \times 10^{-6}$ & 0.5 \\
\hline Inhalation/dermal contact groundwater use & NA & NA & $8 \times 10^{-6}$ & 7 & $1 \times 10^{-5}$ & 8 \\
\hline
\end{tabular}


Section E.3 (U.S. Air Force 1993c) discusses metals that have no groundwater background data. No background data exist for surface waters.

Except for lead, the concentrations of all metals in all media were not considered the result of base activities. Except for lead, no known human-caused sources of metals exist at OU2.

Because risk assessments were performed on five sets of sites at OU2, this ROD does not present quantified carcinogenic risks and HQs for each contaminant of concern in each exposure medium for each exposure pathway. Appendix K of the BLRA (U.S. Air Force 1993c) summarizes these data.

Table 21 indicates that excess cancer risk to human health in a future residential land-use scenario presents an unacceptable risk at ST10 and SS14. Furthermore, the HI is greater than unity. Based on these estimates, the primary exposure pathway of concern for ST10 and SS14 under all land-use scenarios is the consumption and use of contaminated Table groundwater. Ingestion of and dermal contact with contaminated surface soils and shallow sediments may also present an excess cancer risk greater than $1 \times 10^{-6}$ under the future residential scenario.

The contaminants of concern in groundwater are BTEX, anthracene, and naphthalene. Benzene contamination of subsurface soil may also present a future risk to groundwater.

Based on the BLRA (U.S. Air Force 1993c), the only exposure pathway of potential concern for ST11 is inhalation of and dermal contact with benzene during use of contaminated groundwater. However, the cumulative risk from all potential pathways does not present an unacceptable risk (Table 22).

The primary exposure pathway of concern for ST.13 and DP26 under the future land-use scenarios (Table 23) is the consumption and use of contaminated groundwater. Ingestion of and dermal contact with contaminated surface soils may also present an excess cancer risk greater than $1 \times 10^{-6}$ under all of the land-use scenarios. Ingestion of vegetables grown in contaminated soil may present an excess cancer risk greater than $1 \times 10^{-6}$ for the future residential scenario.

The contaminants of concern in groundwater are BTEX and naphthalene. Benzene, ethylbenzene, and toluene contamination of subsurface soil may also present a future risk to groundwater.

The primary exposure pathway of potential concern for ST18 is the consumption and use of contaminated groundwater (Table 24). Ingestion of and dermal contact with contaminated surface soils and ingestion of vegetables grown in contaminated soil may also present an excess cancer risk greater than $1 \times 10^{-6}$ under the future residential scenario. However, the cumulative risk from all potential pathways does not present an unacceptable risk.

The only exposure pathway of potential concern for ST19 is the consumption and use of contaminated groundwater (Table 25). The cumulative risk from all potential pathways does not present an unacceptable risk ; however, the HI, based on the potential for future leaching of contaminants to groundwater, exceeds unity. 


\subsubsection{Uncertainty}

Health risk assessment methodology has inherent uncertainty associated with how accurately the calculated risk estimates represent the actual risk. The effects of the assumptions and the uncertainty factors may not be known. Usually, the effect is difficult to quantify numerically (e.g., in terms of an error bar). As a result, the effect is discussed qualitatively. Some of the assumptions and uncertainty factors associated with the BLRA include the following:

- This assessment used EPA Region 10 default exposure parameters for most calculations. Some of these parameters are not realistic for a subarctic climate (may overestimate risk).

- The toxicity of TPH and lead is inconclusive; neither was included in the primary calculations in the BLRA (may underestimate risk).

- Existing concentrations are assumed to be the concentrations or exposure source terms in the future. No reduction from natural degradation and attenuation over time is taken into account except where fate and transport modeling has been performed (ST19). No increase because of additional contamination is assumed (except where fate and transport modeling was performed). Potential degradation products of existing organic contaminants (e.g., benzene) are not considered (may overestimate or underestimate risk).

- The groundwater detection limits for some organic and inorganic contaminants, especially PAHs, are higher than risk-based screen concentrations (may underestimate risk).

- Most sampling at the OU2 sites was conducted during the late summer. Seasonal changes may impact soils and groundwater contamination (may overestimate or underestimate risk).

- Surface soil samples were composited from three to five locations. They may have missed hot spots of surface contamination (may underestimate risk).

- Primary risk calculations were based on data collected during the 1991 field season. This data set presents only a brief snapshot of site contamination (may overestimate or underestimate risk).

- Comprehensive soil analyses were analyzed where TPH was most concentrated. This analysis may not have been the most representative of volatile and semivolatile contamination (may underestimate risk).

\subsection{Environmental Risks}

No acute ecological hazards were identified at OU2. Both ST10 and ST11 are adjacent to surface water bodies, Hardfill Lake and Garrison Slough, respectively. Benzene, at a concentration of $2 \mu \mathrm{g} / \mathrm{L}$, was the only organic contaminant detected in the waters of Hardfill Lake; no organic contaminants were detected in Garrison Slough adjacent to ST11. The metals concentrations in these surface waters were less than or equivalent to their concentrations in the adjacent groundwaters. Total lead in Hardfill Lake had a maximum concentration of $1.7 \mu \mathrm{g} / \mathrm{L}$. No contaminants were detected above risk-based standards in the sediments at ST11. PAHs, PCB, and DDD were detected in the sediments at ST10. 
Hardfill Lake is downgradient of the contaminated groundwater at ST10 and SS14. In the past (U.S. Air Force 1993a), sheens and odors have been reported for the surface waters at Hardfill Lake. Thus, there is a strong potential that contaminants may flow into the lake and affect environmental receptors.

An ecological risk assessment is presently under way as part of the Eielson AFB site-wide study.

\subsection{Description of Alternatives}

A feasibility study (FS) was performed as part of the OU2 RI/FS process. This section of the ROD describes the remedial alternatives proposed in the FS. For more details, see the FS (U.S. Air Force 1993d).

\subsection{Remedial Action Objectives (RAOS)}

RAOs are developed to specify actions and contaminant levels necessary to provide protection of human health and the environment. RAOs define the contaminants of concern, exposure routes and receptors, and an acceptable contaminant level for each exposure route (i.e., a remediation goal). The results of the baseline risk assessment (U.S. Air Force 1993c) are used to determine the potential for current or future risk from a given source area and to identify acceptable contaminant levels for each exposure pathway. Health-based applicable or relevant and appropriate requirements (ARARs) are also used to establish remediation goals when they are available. In addition, groundwater concentrations are compared to drinking water standards as specified by the EPA's groundwater protection strategy. The goal of EPA's Superfund approach is to return usable groundwaters to their beneficial uses within a timeframe that is reasonable given the particular circumstances of the site.

\subsubsection{Source Areas ST11 and ST18}

For source areas ST11 and ST18, the cumulative risk from all current and future potential pathways is within acceptable regulatory levels, and groundwater concentrations do not exceed MCLs. Soil and groundwater concentrations are protective of human health and the environment and, therefore, no remedial action is required at these source areas.

Although no action is required under CERCLA, the U.S. Air Force will remove the tanks at ST18 under the Underground Storage Tank Program. In addition, if the drywell at ST18 can be located and removed without damaging the existing structures, it will be removed. Confirmatory soil samples will be collected in either case. The U.S. Air Force will also continue to monitor groundwater at these areas to ensure that contaminant levels remain protective of human health and the environment.

\subsubsection{Source Area ST19}

The exposure pathway of potential concern for ST19 is consumption and use of contaminated groundwater in the event that groundwater directly adjacent to the spill area is used in the future. Groundwater concentrations at levels approximately two times the MCLs for benzene and toluene were found in one monitoring well (19-02A) located approximately 150 feet from the spill area. Fate and transport modeling conducted for this area indicate that benzene and toluene concentrations have been and will continue 
decreasing. Using conservative modeling assumptions, the modeled peak concentration for ethylbenzene is estimated to be approximately $900 \mu \mathrm{g} / \mathrm{L}$ and, therefore, may exceed its MCL of $700 \mu \mathrm{g} / \mathrm{L}$ at some time in the future. Xylene concentrations are not expected to exceed the MCL.

Soil and groundwater sampling results and the fate and transport modeling both indicate that the contamination at ST19 is restricted to a limited area (approximately 2 acres) directly adjacent to the spill area and that the weathered petroleum contamination in subsurface soils is not expected to act as a significant continuing source of groundwater contamination. Groundwater concentrations in wells located downgradient within 1,000 feet of the spill area do not exceed MCLs. In addition, ST19 is located in a remote area of the base that is not likely to be used for residential purposes in the foreseeable future. Given the low level of residual contamination present and the limited area impacted, no remedial action will be taken at ST19. Institutional controls (e.g., command directives and protective covenants) will be established to prevent the use of groundwater at ST19 and the groundwater will continue to be monitored to verify the results of the fate and transport modeling and to ensure protectiveness of human health and the environment.

\subsubsection{Source Areas ST10, SS14, ST13, and DP26}

Based on findings of the RI and BLRA, source areas ST10, SS14, ST13, and DP26 require remedial action because of the potential risk from unrestricted domestic use of groundwater. These source areas are characterized by the presence of petroleum-derived contaminants in the soil (BTEX and naphthalenes), floating fuel in the smear zone at the top of the water table, and petroleum-derived contaminants (BTEX, naphthalenes, total lead) in the groundwater. The potential risks are primarily associated with BTEX, total lead, and naphthalene in the groundwater. The soils do not pose an unacceptable risk due to ingestion or dermal contact under either the current industrial or future residential scenarios, but residual contamination in the soil and smear zone may be a continuing source of releases to the groundwater, and, therefore, may also contribute to the potential risk. The chemicals of concern by media for the four source areas recommended for remedial action are summarized in Table 26.

\begin{tabular}{||l|l|l||}
\hline \multicolumn{2}{|c||}{ TABLE 26. Chemicals of Concern by Media } \\
\hline \hline Media & ST10 and SS14 & ST13 and DP26 \\
\hline Groundwater & Benzene & Benzene \\
& Toluene & Toluene \\
& Ethylbenzene & Ethylbenzene \\
& Xylenes \\
& Xylenes & Naphthalenes \\
& Naphthalenes & Total lead \\
& Total lead & Benzene \\
& Benzene & Toluene \\
Ethylbenzene \\
Xylenes \\
Subsurface soil & Naphthalenes & \\
& & \\
& & \\
\hline
\end{tabular}

The RAOs for the OU2 source areas are summarized in Table 27.

To achieve these objectives, remediation goals (Table 28) that identify acceptable contaminant levels in soils and groundwater have been developed from risk-based concentrations and chemical-specific ARARs. 


\begin{tabular}{|c|c|}
\hline \multicolumn{2}{|r|}{ TABLE 27. Remedial Action Objectives } \\
\hline Environmental Media & Remedial Action Objectives \\
\hline \multirow{5}{*}{ Groundwater } & For Human Health: \\
\hline & $\begin{array}{l}\text { Prevent use of water having carcinogens (benzene) in } \\
\text { excess of MCLs. }\end{array}$ \\
\hline & $\begin{array}{l}\text { Prevent use of water having non-carcinogens (toluene, } \\
\text { ethylbenzene, xylenes, naphthalenes, total lead) in excess } \\
\text { of MCLs or RfDs }\end{array}$ \\
\hline & For Environmental Protection: \\
\hline & $\begin{array}{l}\text { Restore aquifer to its designated beneficial use as a } \\
\text { drinking water source }\end{array}$ \\
\hline \multirow[t]{2}{*}{ Soil } & For Environmental Protection: \\
\hline & $\begin{array}{l}\text { Prevent migration of contaminants that would result in } \\
\text { groundwater contamination in excess of MCLs or health- } \\
\text { based levels. }\end{array}$ \\
\hline
\end{tabular}

\begin{tabular}{|c|c|c|}
\hline \multicolumn{3}{|c|}{ TABLE 28. Final Remediation Goals } \\
\hline Chemical Compound & $\begin{array}{l}\text { Groundwater } \\
(\mu g / L)\end{array}$ & $\begin{array}{c}\text { Soil/Shallow } \\
\text { Sediments } \\
(\mathbf{m g} / \mathbf{k g})\end{array}$ \\
\hline Benzene & $5(a)$ & $0.2^{(b)}$ \\
\hline Toluene & $1,000(a)$ & $80(b)$ \\
\hline Ethylbenzene & $700(a)$ & 140 (b) \\
\hline Xylenes & $10,000(a)$ & $760(b)$ \\
\hline $\begin{array}{l}\text { Naphthalenes: } \\
\text { 2-Methylnaphthalene } \\
\text { Naphthalene }\end{array}$ & $\begin{array}{l}140(c) \\
220(c)\end{array}$ & $\begin{array}{c}150(b) \\
21(b)\end{array}$ \\
\hline Lead & $15(\mathrm{a})$ & $500(d)$ \\
\hline \multicolumn{3}{|c|}{$\begin{array}{l}\text { (a) Based on chemical-specific ARARs. } \\
\text { (b) Based on leaching to groundwater [Appendix D of FS (U.S. Air Force } \\
1993 d \text { )]. } \\
\text { (c) Based on risk-based contaminant of concern cutoff concentration equivalent } \\
\text { to a Hazard Quotient of } 0.1 \text { (U.S. Air Force 1993c). } \\
\text { (d) Based on the EPA biokinetic uptake model. }\end{array}$} \\
\hline
\end{tabular}

As stated previously, the primary RAO is protection of groundwater. The secondary remediation goals developed for soil are based on fate and transport modeling and may be modified if additional information becomes available indicating that an alternative level of soil remediation is protective of groundwater.

\subsection{ST10 and SS14 Remedial Alternatives}

Six alternatives were developed in the FS and five were analyzed in detail for ST10 and SS14. The sixth alternative proposed the complete removal of source (floating fuel and contaminated soils) and extraction and treatment of contaminated groundwater. It would include excavation of soils down to the water table and removal of the floating fuel layer, 
approximately 540,000 cubic yards of soil. This alternative was screened out because it was not considered implementable; it would have required complete demolition of the E-2 POL Storage Area, and cost approximately $\$ 39,000,000$.

The five alternatives analyzed in detail are listed below. ARARs for each alternative are summarized in Table 29.

\begin{tabular}{|c|c|c|c|c|c|c|}
\hline \multirow[t]{2}{*}{ ARARs } & \multirow{2}{*}{$\begin{array}{c}\text { Applicable Regulations } \\
\text { and Codes }\end{array}$} & \multicolumn{5}{|c|}{ Remedial Alternatives } \\
\hline & & 1 & 2 & 3 & 4 & 5 \\
\hline \multicolumn{7}{|l|}{ Action-Specific: } \\
\hline Alaska soil waste management & 18 AAC 60 & & & A & A & A \\
\hline Alaska hazardous waste regulations & 18 AAC 62 & & & A & $\mathrm{A}$ & $\mathrm{A}$ \\
\hline |RCRA land disposal restrictions & 40 CFR 268 & & & & A & A \\
\hline RCRA waste piles regulations & 40 CFR 264.251 & & A & A & A & A \\
\hline Federal Clean Air Act & 42 USC 7401 & & & & A & A \\
\hline AWQC and Alaska discharge standards & AWQC $\S 304 / 18$ AAC 70 & & A & A & $\mathrm{A}$ & $\mathrm{A}$ \\
\hline \multicolumn{7}{|l|}{ Chemical-specific: } \\
\hline MCL, non-zero MCLGs, and action levels & 40 CFR 141/18 AAC 80 & & $\mathrm{R}$ & $\mathrm{R}$ & $\mathrm{R}$ & $\mathrm{R}$ \\
\hline Alaska water quality standards & 18 AAC 70 & & A & A & A & A \\
\hline Alaska oil pollution regulations & 18 AAC 75 & & & A & A & A \\
\hline Alaska regulations for leaking USTs & 18 AAC 78 & & & $\mathbf{R}$ & $\mathrm{R}$ & $\mathrm{R}$ \\
\hline \begin{tabular}{|l} 
A-applicable \\
R-relevant and appropriate \\
AWQC=Ambient Water Quality Criteria \\
$M C L=$ maximum contaminant level \\
MCLG=maximum contaminant level goal \\
UST=underground storage tank
\end{tabular} & & & & & & \\
\hline
\end{tabular}

\subsubsection{Alternative 1: No Action Alternative}

Under this alternative, no action would be taken to remove the floating fuel or remediate contaminated soils or groundwater. No monitoring of soil or groundwater would be conducted.

\subsubsection{Alternative 2: Limited Action Alternative}

Under this alternative, no action would be taken to remove the floating fuel or remediate contaminated soils or groundwater. Contaminants in the floating fuel, soil, and groundwater would be allowed to disperse and degrade through natural attenuation. Some natural groundwater treatment would continue through volatilization of contaminants discharged to Hardfill Lake.

Institutional controls prohibiting domestic use of groundwater within the contaminated area would remain in place for as long as the contaminant concentrations in groundwater exceed MCLs. Drinking water would continue to be supplied to the area from the main base water supply system.

Groundwater monitoring would be conducted to evaluate contaminant migration and compliance with final remediation goals. 


\subsubsection{Alternative 3: Bioventing Alternative}

This alternative would employ passive skimming devices without gradient enhancement to remove as much of the floating fuel as possible near the source and to prevent further seeping of free phase fuel into Hardfill Lake. Bioventing would be conducted in the areas where BTEX compounds were found in the subsurface soils at concentrations that might present a future risk to groundwater. The total surface area biovented is approximately 30,000 square feet.

Passive skimming will be used where free product is sufficiently mobile to flow, without an induced gradient, into wells and trenches. Its effectiveness will be evaluated before fullscale implementation. The bioventing process uses a series of wells that inject air into the soil. The oxygen in the air sustains and promotes the growth of naturally occurring microorganisms that break down the fuel contamination.

This alternative addresses groundwater contamination by source reduction. It does not include active remediation of the floating product and the smear zone soils.

Institutional controls prohibiting domestic use of groundwater within the contaminated area would remain in place for as long as the contaminant concentrations in groundwater exceed MCLs. Drinking water would continue to be supplied to the area from the main base water supply system. Groundwater monitoring would be conducted to evaluate contaminant migration and compliance with final remediation goals.

\subsubsection{Alternative 4: Bioventing/Soil Vapor Extraction/Air Sparging/Passive Skimming Alternative}

This alternative would combine bioventing, soil vapor extraction (SVE), and possibly air sparging to enhance volatilization and degradation of volatile organic compounds from the vadose zone, smear zone, and floating fuel layer in areas where the layer is thin. The area treated would include all of the site underlain by floating fuel, approximately 326,000 square feet. Air would be introduced into the groundwater through injection wells for in situ stripping of volatile organic compounds. The volatile organic compounds would be removed using vapor extraction wells screened from the seasonal low water table up through the vadose zone. A vacuum applied to the extraction wells would pull air through the soils and across the surface of the floating fuel. Air emission controls would be installed on the SVE system if needed.

A cap may be used with the SVE system to enhance extraction efficiency (i.e., reduce the number of extraction wells required) and prevent short circuiting. The cap would cover the surface above the SVE treatment area. This cap would also help reduce infiltration and migration of contaminants to the groundwater.

The frequency of switching between SVE and bioventing will be determined during the phased approach. Since both systems will use the same plumbing systems, switching between the systems will be readily implementable. For example, the SVE system could be converted to bioventing for biodegradation of heavier fuel constituents in the soil. The shallow extraction wells could be converted to low-volume air injection wells to optimize oxygen availability for microbial growth. Passive or active heating of the soil would be an option. Implementation of the phased approach will be based on monitoring of the volatile organic compound (VOC)-contaminated soils and floating fuel layer during remediation. 
Passive skimming devices would be used to remove floating fuel and prevent fuel from seeping into Hardfill Lake. Passive skimming will be used where free product is sufficiently mobile to flow, without an induced gradient, into wells and trenches. Collection trenches that extend several feet below the water table would also be installed perpendicular to the direction of groundwater flow. The floating fuel would enter slotted pipes in the trench and flow by gravity to a sump where the oil would be removed using a skimmer pump. Its effectiveness will be evaluated before full-scale implementation.

This alternative addresses groundwater contamination by source reduction. It does include active remediation of the floating product and the smear zone soils.

Institutional controls prohibiting domestic use of groundwater within the contaminated area would remain in place for as long as the contaminant concentrations in groundwater exceed MCLs. Drinking water would continue to be supplied to the area from the main base water supply system. Groundwater monitoring would be conducted to evaluate contaminant migration and compliance with final remediation goals

\subsubsection{Alternative 5: Soil Excavation/Groundwater Treatment Alternative}

This alternative would include removal of known subsurface soil hot spots to the extent practicable. Unsaturated soils (vadose and upper portion of the smear zone) that exceed the final remediation goals for protection of groundwater would be excavated where excavation is feasible without disrupting base activities and facilities. Because the two source areas are adjacent to fuel outlets, above-ground and below-ground storage tanks, pipelines, buildings, and other facilities, only a small portion of the soil contaminated above final remediation goals may actually be excavated. The maximum surface area of the excavation is approximately 30,000 square feet with an anticipated volume of 6,700 cubic yards of soil excavated. The excavated soils could be treated by ex situ bioremediation (e.g., composting).

This alternative would also include installation of product and groundwater extraction wells with dual-phase active skimmer pumps to remove the floating fuel and contaminated groundwater. The use of dual-phase pumps would create a small localized cone of depression in the water table, enhancing free phase fuel flow to the skimming wells. The effectiveness of active skimming will be evaluated before full-scale implementation. The groundwater extracted during implementation of this alternative would be treated by air stripping and carbon adsorption to remove the volatile organic compounds. Pretreatment to remove iron, arsenic, and lead may be required to prevent equipment fouling and to meet discharge limits. The treated groundwater would be discharged to Hardfill Lake. Air pollution controls would be installed if needed for protection of human health or compliance with ARARs.

This alternative addresses groundwater contamination by extraction and treatment. It does include active remediation of the floating product and the smear zone soils where they are accessible. A significant volume of soils may not be accessible for excavation.

Institutional controls prohibiting domestic use of groundwater within the contaminated area would remain in place for as long as the contaminant concentrations in groundwater exceed MCLs. Drinking water would continue to be supplied to the area from the main base water supply system. Groundwater monitoring would be conducted to evaluate contaminant migration and compliance with final remediation goals 


\subsection{ST13 and DP26 Remedial Alternatives}

The five alternatives developed in the FS and analyzed in detail for ST13 and DP26 are summarized below.

\subsubsection{Alternative 1: No Action Alternative}

This alternative is identical to the no action alternative for ST10 and SS14 (Section 7.2.1) and assumes that no action would be taken to remove or remediate the floating fuel, contaminated soils, or groundwater. No monitoring of soil or groundwater would be conducted.

\subsubsection{Alternative 2: Limited Action Alternative}

Under this alternative, no action would be taken to remove the floating fuel or remediate contaminated soils or groundwater. Contaminants in the floating fuel, soil, and groundwater would be allowed to disperse and degrade through natural attenuation.

Institutional controls prohibiting domestic use of groundwater within the contaminated area would remain in place for as long as the contaminant concentrations in groundwater exceed MCLs. Drinking water would continue to be supplied to the area from the main base water supply system.

Groundwater monitoring would be conducted to evaluate contaminant migration and compliance with final remediation goals.

\subsubsection{Alternative 3: Bioventing Alternative}

This alternative would employ passive skimming devices without gradient enhancement to remove the floating fuel near Tank 300 . Bioventing would be conducted in the areas where floating fuel exists and where BTEX compounds were found in the subsurface soils at concentrations that might present a future risk to groundwater. The total surface area biovented is approximately 128,000 square feet.

Passive skimming will be used where free product is sufficiently mobile to flow, without an induced gradient, into wells and trenches. Its effectiveness will be evaluated before fullscale implementation. The bioventing process uses a series of wells that inject air into the soil. The oxygen in the air sustains and promotes the growth of naturally occurring microorganisms that break down the fuel contamination.

This alternative addresses groundwater contamination by source reduction. It does not include active remediation of the floating product and the smear zone soils.

Institutional controls prohibiting domestic use of groundwater within the contaminated area would remain in place for as long as the contaminant concentrations in groundwater exceed MCLs. Drinking water would continue to be supplied to the area from the main base water supply system. Groundwater monitoring would be conducted to evaluate contaminant migration and compliance with final remediation goals. 


\subsubsection{Alternative 4: Bioventing/Soil Vapor Extraction/Air Sparging/Active Skimming/Groundwater Treatment Alternative}

This alternative would combine bioventing, SVE, and possibly air sparging to enhance volatilization and degradation of volatile organic compounds from the vadose zone, smear zone, and floating fuel layer in areas where the layer is thin. These remedial technologies would be implemented in the areas where floating fuel exists and where BTEX compounds were found in the subsurface soils at concentrations that might present a future risk to groundwater. The total surface area of the treated area is approximately 128,000 square feet.

Air would be introduced into the groundwater through injection wells for in situ stripping of volatile organic compounds. The volatile organic compounds would be removed using vapor extraction wells screened from the seasonal low water table up through the vadose zone. A vacuum applied to the extraction wells would pull air through the soils and across the surface of the floating fuel. Air emission controls would be installed on the SVE system if needed. The frequency of switching between SVE and bioventing will be determined during the phased approach. Since both systems will use the same plumbing systems, switching between the systems will be readily implementable. For example, the SVE system could be converted to bioventing for biodegradation of heavier fuel constituents in the soil. The shallow extraction wells could be converted to low-volume air injection wells to optimize oxygen availability for microbial growth. Passive or active heating of the soil would be an option. Implementation of the phased approach will be based on monitoring of the VOC-contaminated soils and floating fuel layer during remediation.

A cap may be used with the SVE system to enhance extraction efficiency and prevent short circuiting. The cap would be placed over the surface of the area. The cap would also help reduce infiltration and potential migration of contaminants from soils to the groundwater.

This alternative would also include the installation of a product and groundwater extraction well near Tank 300 for active skimming of the floating fuel layer. The well would be equipped with a dual-phase skimmer pump to enhance fuel flow to the well. The effectiveness of active skimming will be evaluated before full-scale implementation. When no additional measurable floating fuel can be removed, groundwater would be extracted from the area with lead concentrations above final remediation goals. The groundwater extracted during implementation of this alternative would be treated by precipitation to remove the lead and air stripping to remove the volatile organic compounds.

The distal end of the benzene groundwater plume will be monitored annually for 5 years, at which time the need for further monitoring will be reevaluated. If the plume is expanding, groundwater may be extracted from near the plume's distal end to prevent contaminant migration further downgradient. The groundwater extracted from the hydraulic containment well would also be treated in the precipitation/air stripping system.

This alternative addresses groundwater contamination by source reduction and by extraction and treatment of contaminated groundwater. It does include active remediation of the floating product and the smear zone soils.

Institutional controls prohibiting domestic use of groundwater within the contaminated area would remain in place for as long as the contaminant concentrations in groundwater exceed MCLs. Drinking water would continue to be supplied to the area from the main base water supply system. Groundwater monitoring would be conducted to evaluate contaminant migration and compliance with final remediation goals. 


\subsubsection{Alternative 5: Soil Excavation/Groundwater Treatment Alternative}

This alternative would include removal of known subsurface soil hot spots to the extent practicable. Unsaturated soils (vadose and upper portion of the smear zone) that exceed the final remediation goals for protection of groundwater would be excavated where excavation is feasible without disrupting base activities and facilities. Because the two source areas are adjacent to active taxiways, fuel outlets, above-ground and below-ground storage tanks, pipelines, buildings, and other facilities, only a small portion of the soil contaminated above final remediation goals may actually be excavated. The maximum surface area of the excavation is approximately 3,000 square feet with an anticipated 660 cubic yards of soils excavated. The excavated soils could be treated by ex situ bioremediation (e.g., composting).

This alternative would also include installation of product and groundwater extraction wells with dual-phase active skimmer pumps to remove the floating fuel and contaminated groundwater. The use of dual-phase pumps would create a small localized cone of depression in the water table, enhancing free phase fuel flow to the skimming wells. The effectiveness of active skimming will be evaluated before full-scale implementation. The groundwater extracted during implementation of this alternative would be treated by air stripping and carbon adsorption to remove the volatile organic compounds. Pretreatment to remove iron, arsenic, and lead may be required to prevent equipment fouling and to meet discharge limits. The treated groundwater would be discharged to surface water bodies. Air pollution controls would be installed if needed for protection of human health or compliance with ARARs.

This alternative addresses groundwater contamination by extraction and treatment. It does include active remediation of the floating product and the smear zone soils where they are accessible. A significant volume of soils may not be accessible for excavation.

Institutional controls prohibiting domestic use of groundwater within the contaminated area would remain in place for as long as the contaminant concentrations in groundwater exceed MCLs. Drinking water would continue to be supplied to the area from the main base water supply system. Groundwater monitoring would be conducted to evaluate contaminant migration and compliance with final remediation goals

\subsection{Summary of the Comparative Analysis of Alternatives}

In accordance with federal regulations, the five cleanup alternatives were evaluated based on the nine criteria presented in the National Contingency Plan (NCP). The results of this evaluation are discussed in this section and depicted in Table 30.

\subsection{Overall Protection of Human Health and the Environment}

All the alternatives, except Alternative 1, would use institutional controls to prevent the use of contaminated groundwater until cleanup standards are achieved. Alternatives 4 and 5 would provide the greatest protection of human health and the environment and the greatest degree of cleanup by treating petroleum contamination in the soil and by treating contaminated groundwater. Alternative 3 would provide limited protection by treating some of the soil contamination and partially reducing the source of groundwater contamination. However, Alternative 3 does not include groundwater treatment. 
TABLE 30. Comparison of Cleanup Alternatives Using the Five Balancing Criteria. Alternatives are ranked by comparing them to each other.

\begin{tabular}{|c|c|c|c|c|}
\hline \multirow[b]{2}{*}{ Evaluation Criteria } & \multicolumn{4}{|c|}{ Alternative Number and Ranking } \\
\hline & 1 and 2 & 3 & 4 & 5 \\
\hline Long-Term Effectiveness and Permanence & 0 & $\odot$ & $\boldsymbol{\square}$ & $\Delta$ \\
\hline Reduction of Toxicity, Mobility, and Volume & 0 & $\boldsymbol{O}$ & $\bar{\Delta}$ & $\Delta$ \\
\hline Short-Term Effectiveness & 0 & $\odot$ & $\mathbf{O}$ & $\bar{\Delta}$ \\
\hline Implementability & 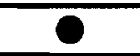 & 0 & $\bar{\Delta}$ & 0 \\
\hline \multicolumn{5}{|l|}{ Cost } \\
\hline ST10 and SS 14 & 9 & $\boldsymbol{\nabla}$ & $\odot$ & $\mathrm{O}$ \\
\hline ST13 and DP26 & $\mathbf{0}$ & $\bar{\square}$ & 0 & $\bar{\Delta}$ \\
\hline Key & $\begin{array}{l}0 \\
0 \\
0 \\
0\end{array}$ & $\begin{array}{l}\text { Best } \\
\text { Good } \\
\text { Poor } \\
\text { Worst }\end{array}$ & & \\
\hline
\end{tabular}

\subsection{Compliance with Applicable or Relevant and Appropriate Requirements}

Alternatives 4 and 5 include groundwater treatment and are expected to achieve groundwater cleanup standards more rapidly than the other alternatives that rely only on natural processes to slowly decrease petroleum and lead concentrations in the groundwater.

Alternatives 3, 4, and 5 would be designed and implemented to meet all applicable or relevant and appropriate state and federal regulations, including air emission limitations, surface water discharge limits, and disposal of byproducts from the groundwater treatment activities.

Alternatives 1 and 2 are not designed to meet all applicable or relevant and appropriate state and federal regulations. Natural dispersion and degradation might eventually reduce contaminant concentrations below ARARs. However, it will take a very long time (decades).

\subsection{Long-Term Effectiveness and Permanence}

Alternative 4 aggressively treats the subsurface soils, including the smear-zone soils. Therefore, Alternative 4 would achieve the best treatment of soils that are continuing to contaminate the groundwater. In addition, Alternative 4 includes treatment of leadcontaminated groundwater at ST13 and DP26.

Alternative 5 includes selective excavation of soils, but large volumes of contaminated soils cannot be excavated because of the presence of pipelines, tanks, and operating systems in the area. In addition, Alternative 5 does not address the significant contamination remaining in the smear-zone soils. Under Alternative 5, the remaining soil contamination is allowed to slowly move through the soil to the groundwater, where it would be pumped out and treated.

Alternative 3 addresses petroleum contamination in soil and, to a lesser extent, in smearzone soils. However, at ST10 and SS14 Alternative 3 treats an area one-tenth the extent of the soils that will be treated using Alternative 4. In addition, because Alternative 3 does not 
include groundwater treatment, groundwater contaminants, including lead, will remain significantly longer than estimated for Alternatives 4 and 5.

None of the contaminants are addressed by Alternatives 1 and 2 except through natural processes. Therefore, Alternatives 1 and 2 provide the least long-term effectiveness and permanence.

\subsection{Reduction of Toxicity, Mobility, or Volume Through Treatment}

Alternatives 4 and 5 result in the greatest reduction in toxicity, mobility, and volume of contamination by removing and/or treating contamination in the soil and above and in the groundwater. Alternative 4 also reduces the volume of lead-contaminated ground water at ST13 and DP26. Alternative 4 aggressively treats the source of groundwater contamination by remediating the subsurface soils, including those in the smear zone.

Alternative 5 does not reduce the soil contamination as effectively, but would include more aggressive groundwater extraction and treatment.

Alternative 3 does not reduce or treat the soil contamination, specifically that in the smearzone soils, as effectively as Alternative 4. In addition, Alternative 3 does not reduce or treat the groundwater contamination.

Neither Alternative 1 nor 2 reduces the toxicity, mobility, or volume of the contaminants through treatment.

\subsection{Short-Term Effectiveness}

None of the alternatives are expected to pose an unacceptable risk to residents or workers during implementation. All potential impacts from construction and system operation will be readily controlled using standard engineering controls and practices.

Alternative 4 is expected to clean the soils, including the smear zone, in the shortest amount of time, thus eliminating the source of groundwater contamination. In addition, by treating lead contamination in the groundwater, Alternative 4 reduces the time necessary to achieve groundwater cleanup standards.

Alternative 5 requires much more time than Alternative 4 to achieve soil cleanup because of the impracticability of excavation for the removal of all the contaminated soils, especially those in the smear zone above the groundwater. Though Alternative 5 includes more extensive groundwater extraction and treatment, it is questionable whether groundwater treatment can achieve cleanup standards faster than natural processes because of the large amounts of remaining soil contamination that would continue to contaminate the groundwater.

Alternative 3 includes some treatment of soil contamination, but does not address contamination in the smear zone or in the groundwater. Therefore, Alternative 3 , as well as Alternatives 1 and 2, depends on natural processes to achieve groundwater cleanup standards. Using only natural processes, groundwater contamination may persist for more than 200 years.

\subsection{Implementability}

All alternatives use readily available technologies and are feasible to construct. Alternatives 1 and 2 are readily implementable because they require no additional action other than 
monitoring and/or institutional controls. The technology described in Alternative 3 is relatively limited in scope and is readily implementable.

The success of removing petroleum products on top of the groundwater as part of Alternatives 3,4, and 5 depends on the amount of petroleum product that flows into the collection system. Effective collection of petroleum is difficult with the thin layers of petroleum products and the large fluctuations in groundwater levels found at Eielson AFB.

The technologies included in Alternative 4 for the removal of petroleum contamination are being implemented at three other fuel-contaminated areas at Eielson AFB. The results to date have been encouraging. These technologies appear to be the most effective method for treating the smear-zone soils on top of the groundwater, where much of the residual petroleum contamination remains.

Alternative 5 would be poor in effectiveness and implementability because it is not possible to excavate large volumes of contaminated soil near pipelines, tanks, and operating systems, nor in the smear-zone soil. Furthermore, although groundwater extraction and treatment is a commonly used technology, its effectiveness in achieving groundwater cleanup standards is not well established. EA (1994) has shown that skimming has not been proven effective at other sites at Eielson AFB with similar thickness of floating product.

\section{$\underline{8.7 \quad \text { Cost }}$}

On the basis of the information available at the time the alternatives were developed, the estimated cost for each alternative is presented in Table 31. The cost estimates are order-ofmagnitude estimates with an intended accuracy of $+50 \%$ and $-30 \%$. The accuracy limits are based on EPA (1988) guidance.

The cost estimates should only be used for comparison between alternatives, and not for comparisons with other facilities, especially if the other sites are in the lower 48 states where costs are lower. Cost estimates, both capital and operations and maintenance, are elevated due to 1) Alaska labor rates that are 30\% higher, and 2) major equipment costs that are $25 \%$ higher. Materials costs were estimated to be comparable with those in the lower 48 states.

The estimated costs for the implementation of Alternative 4 listed in Table 31 have been revised downward since the development of the OU2 Proposed Plan (U.S. Air Force 1993i) and completion of the public comment period. The initial construction cost estimate for Alternative 4 was $\$ 5,150,000$ for ST10 and SS14 and \$3,500,000 for ST13 and DP26. The total cost estimate for Alternative 4 was $\$ 7,400,000$ for ST10 and SS14 and $\$ 12,500,000$ for ST13 and DP26. In addition, the revised costs are better constrained than those calculated and reported in the OU2 Proposed Plan. The cost revision is based on recent results from Eielson AFB onsite experience with cleanup activities. Recent Eielson AFB site experience indicates that remedial technologies can be implemented at a lower capital cost than that calculated in the OU2 FS (U.S. Air Force 1993d) without changing the basic remedial technologies and still achieving the remedial goals listed in Tables 27 and 28. The revised costs are discussed in detail in Section 11 of this ROD.

\subsection{State Acceptance}

The state of Alaska concurs with the actions proposed in this ROD. The following nonCERCLA actions, although outside this ROD, have been projected to occur: 


\begin{tabular}{|c|c|c|c|c|}
\hline \multicolumn{5}{|c|}{ TABLE 31. Cost of Remedial Alternatives (thousands of dollars) ${ }^{(a)}$} \\
\hline Type of Cost & $\begin{array}{c}\text { Alternative } 2 \\
\text { Restricted } \\
\text { Groundwater Use }\end{array}$ & $\begin{array}{l}\text { Alternative } 3 \\
\text { Bioventing }\end{array}$ & $\begin{array}{l}\text { Alternative } 4 \\
\text { Bioventing/Soil Vapor } \\
\quad \text { Extraction/ } \\
\text { Air Sparging/Skimming/ } \\
\text { Groundwater Treatment } \\
\text { (ST13 and DP26 only) }\end{array}$ & \begin{tabular}{|c|} 
Alternative 5 \\
Soil Excavation/ \\
Groundwater \\
Treatment(c)
\end{tabular} \\
\hline \multicolumn{5}{|c|}{$\begin{array}{l}\text { ST 10: Bulk Fuel Storage } \\
\text { 4: Railroad JP-4 Fuel Spill Area }\end{array}$} \\
\hline Construction & 5 & 620 & 1,700 & $2,900 \quad(1,600)$ \\
\hline Total(d) & 1,170 & 2,100 & 3,000 & $9,100 \quad(6,600)$ \\
\hline \multicolumn{5}{|c|}{$\begin{array}{c}\text { ST13: Diesel Fuel Spill } \\
\text { DP26: Fuel Tank Sludge Burial }\end{array}$} \\
\hline Construction & 0 & 830 & $2,200 \quad(1,200)$ & $1,750 \quad(1,400)$ \\
\hline Total & 1,170 & 5,800 & $10,700 \quad(7,100)$ & $10,700 \quad(8,900)$ \\
\hline \multicolumn{5}{|c|}{$\begin{array}{l}\text { (a) Cost estimates are order-of-magnitude; use only for comparison among alternatives. } \\
\text { Alternative } 1 \text { has no associated costs. } \\
\text { (b) Soil venting, air sparging, and groundwater treatment at ST13 and DP26. Soil venting and } \\
\text { air sparging only at ST } 10 \text { and SS14. } \\
\text { (c) Costs in parentheses are for the groundwater treatment component. } \\
\text { (d) Assumes 5\% annual inflation over operational life of remediation. The difference between } \\
\text { this value and Construction costs represents Operation and Maintenance costs. }\end{array}$} \\
\hline
\end{tabular}

- The two 25,000-gallon underground storage tanks at ST18 will be removed in accordance with 18 AAC 78, Underground Storage Tank Regulations. Removal is planned for 1995 .

- In a continuing effort to minimize the risks associated with exposure to contaminated groundwater and to control additional plume migration, dewatering efforts associated with ongoing base activities will be coordinated with the State of Alaska in accordance with 18 AAC 72, Wastewater Disposal Regulations.

\subsection{Community Acceptance}

Community response to the actions proposed in this ROD were generally positive. Only a few public comments were received that questioned some facets of the Proposed Plan. These comments and responses to them are discussed in the final part of this ROD, the Responsiveness Summary.

\subsection{The Selected Remedy}

The cumulative risks for ST11 are within acceptable regulatory levels. An environmental cleanup is not proposed at this site.

The cumulative risks for ST18 are within acceptable regulatory levels. Environmental cleanup is not proposed under Superfund. However, under the Underground Storage Tank Program, the U.S. Air Force will remove the tanks at ST18. If the drywell at ST18 
can be located and can be removed without damaging the existing structures, it will be removed. Confirmatory soil samples will be collected in either case.

No environmental cleanup is proposed for ST19, even though groundwater concentrations at levels approximately two times the MCLs for benzene and toluene were found in one monitoring well (19-02A) located approximately 150 feet from the spill area. Fate and transport modeling conducted for this area indicate that benzene and toluene concentrations have been and will continue decreasing. Using conservative modeling assumptions, the modeled peak concentration for ethylbenzene is estimated to be approximately $900 \mu \mathrm{g} / \mathrm{L}$ and, therefore, may exceed its $\mathrm{MCL}$ of $700 \mu \mathrm{g} / \mathrm{L}$ at some time in the future. Xylene concentrations are not expected to exceed the MCL.

Soil and groundwater sampling results and the fate and transport modeling both indicate that the contamination at ST19 is restricted to a limited area (approximately 2 acres) directly adjacent to the spill area and that the weathered petroleum contamination in subsurface soils is not expected to act as a significant continuing source of groundwater contamination. Groundwater concentrations in wells located downgradient within 1,000 feet of the spill area do not exceed MCLs. In addition, ST19 is located in a remote area of the base that is not likely to be used for residential purposes in the foreseeable future. Given the low level of residual contamination present and the limited area impacted, no remedial action will be taken at ST19. Institutional controls (e.g., command directives and protective covenants) will be established to prevent the use of groundwater at ST19 and the groundwater will continue to be monitored to verify the results of the fate and transport modeling and to ensure protectiveness of human health and the environment.

Source areas ST10, SS14, ST13, and DP26 will require cleanup. Based upon consideration of the requirements of CERCLA, the detailed analysis of the alternatives using the nine criteria, and public comments, the U.S. Air Force, ADEC, and EPA have determined that Alternative 4 is the most appropriate remedy for both sets of sites. Major components of the selected remedy include:

- Install an active skimming system to remove fuel floating atop the groundwater at ST13 and DP26, where the product is sufficiently mobile to be recoverable.

- Install passive skimming systems to remove fuel floating atop the groundwater and to prevent fuel from seeping into Hardfill Lake at ST10 and SS14, where the product is sufficiently mobile to be recoverable.

- Install a bioventing and SVE system to remediate soil contamination that poses a threat to groundwater through leaching. This system may include air sparging within the upper part of the groundwater table and the smear zone to volatilize and promote bioremediation of the contaminants. This entire system is also anticipated to reduce fuel floating atop the groundwater.

- Install groundwater extraction and treatment facilities in areas of highest groundwater lead concentrations at ST13 and DP26. The physical/chemical treatment of the groundwater includes precipitation of metals and air stripping of volatile organic compounds.

- Monitor groundwater at ST19, ST10, SS14, ST13, and DP26 to evaluate contaminant levels and migration until remediation levels are achieved.

- Monitor the distal end of the contaminant plume at ST13 and DP26 to evaluate if the plume is expanding. Monitoring will continue for 5 years, at which time the need for 
further monitoring will be reevaluated. Hydraulically contain the grouradwater plume at ST13 and DP26 by extracting groundwater from near the plume's distall end, if the plume is expanding. The groundwater extracted from the hydraulic combainment well will be treated in the physical/chemical system.

- Notify the regulatory agencies of proposed dewatering activities, amed exaluate their potential for impacting areas of groundwater contamination.

- Remove the drywell south of ST18 and test soils for contamination, if it can be located and removed without damaging the existing structures. If the drywell cammot be located, conduct confirmatory sampling.

- Monitor the groundwater near ST11, ST18, and selected SER sites, including SS31, to verify that contaminant concentrations, if any, remain within acceptable screening levels. Monitoring will continue for 5 years, at which time the need for further monitoring will be reevaluated.

- Implement institutional controls to prevent exposure to contaminated groundwater. In the event of base closure, any remaining contaminated sites will be adidiessed in accordance with CERCLA Section 120.

- Perform supplemental soil sampling during 1994 in the vicinity of Buillding 6214 (ST16) during 1994 to confirm that no significant contamination remaims.

Alternative 4 achieves substantial risk reduction through treatment of the primcipal sources of groundwater contamination-fuels on top of the groundwater and soil comtamination. Groundwater monitoring and institutional controls will continue in both areas to restrict the use of groundwater. Hardfill Lake will prevent expansion of the plume at ST10 and SS14 because contamination entering the water evaporates at the surface. The lead in the groundwater at ST13 and DP26 will be actively treated by a groundwater extraction system. BTEXs in groundwater will be expected to diminish due to removal of the source.

The goal of this remedial action is to restore groundwater to its beneficial mse within a timeframe that is reasonable given the particular circumstances of the site. Based on information obtained during the $\mathrm{RI}$ and on a careful analysis of all remedial alternatives, U.S. Air Force, state of Alaska, and EPA believe that the selected remedives will achieve this goal.

It may become apparent, during implementation or operation of the growndwater extraction system and its modifications at ST13 and DP26, that lead levels have ceased to decline and are remaining constant at levels higher than the remediation goals over some portion of the contaminated plume. In such a case, the system performance standards and/or the remedy may be evaluated. Groundwater contamination may be especially persistent in the immediate vicinity of the contaminants' source, where concentrations are relatively high. The ability to achieve final remediation goals at all points throughout the area of attainment, or plume, cannot be determined until the extraction system has been implemented and modified as necessary, and plume response monitored over time. If the selected remedy cannot meet the final remediation goals, at any or all of the monitoring points during implementation, the contingency measures (bulleted below) and goals described in this section may replace the selected remedy and goals for these portions of the plume. Such contingency measures will, at a minimum, prevent further migration of the plume and include a combination of containment technologies and institutional controls. These measures are considered to be protective of human health and the enviromment, and are technically practicable under the corresponding circumstances. 
The selected remedy will include groundwater extraction for an estimated period of 5 years, dependent upon review, during which time the system's performance will be carefully monitored on a regular basis and adjusted as warranted by the performance data collected during operation. Modifications may include any or all of the following:

- pulse pumping to allow aquifer equilibration and encourage adsorbed contaminants to partition into groundwater

- installation of additional extraction wells to facilitate or accelerate cleanup of the contaminant plume.

To ensure that cleanup goals continue to be maintained, the aquifer will be monitored where pumping has ceased. Monitoring will be conducted on an annual basis, dependent upon review.

The remediation will be implemented with a phased approach, where ongoing monitoring will evaluate the performance of each technology before proceeding to the next phase of cleanup. Because the principal focus of the cleanup is the remediation of floating fuel and VOC-contaminated soils, much of monitoring will focus on the capillary fringe and unsaturated zone. The phased approach will allow the U.S. Air Force to use field data during cleanup to get the best mix of technologies to meet cleanup objectives. The costs included in Table 31 are conservative because it was assumed that all components of the system will be required. If some of the components are not required, the actual costs may be significantly lower.

The underground fueling system at ST13 and DP26 is scheduled for replacement in 1994. An estimated 12,000 cubic yards of soil will be excavated during this replacement; of this volume, 7,000 cubic yards are believed to be contaminated. These soils are among the most contaminated at the site, and they will be treated as part of the construction project. The selected remedy for ST13 and DP26 may be affected by this project and may have to be reevaluated after the excavation and soil treatment is completed.

\subsection{Statutory Determinations}

The selected remedy meets statutory requirements of Section 121 of CERCLA, as amended by SARA, and to the extent practicable, the NCP. The evaluation criteria are discussed below.

\subsection{Protection of Human Health and the Environment}

The selected remedies protect human health and the environment through the removal of the principal sources of groundwater contamination and the extraction and treatment of leadcontaminated groundwater (ST13 and DP26 only). VOC-contaminated groundwater will be remediated through removal of the source of continuing groundwater contamination. During the cleanup, institutional controls will eliminate the threat of exposure to contaminated groundwater.

The two principal sources of groundwater contamination are floating fuel and VOCcontaminated soils. The floating fuel will be removed by vapor extraction, bioventing, air sparging, and passive removal (ST10 and SS14) or active skimming (ST13 and DP26); soil contamination will be removed by vapor extraction, bioventing, and air sparging. 
Removal of the source of VOC-contaminated groundwater and extraction and treatment of the lead-contaminated groundwater (ST13 and DP26 only) will eliminate the threat of exposure to these contaminants from ingestion and inhalation of groundwater. The BLRA (U.S. Air Force 1993c) estimated a reasonable maximum exposure risk for residential landuse from these exposure pathways at $2 \times 10^{-3}$ for carcinogenic risk with a $\mathrm{HI}$ of 4 for noncarcinogenic risks at ST10 and SS14; the estimate for ST13 and DP26 is $5 \times 10^{-4}$ for carcinogenic risk and a $\mathrm{HI}$ of 3 for noncarcinogenic risk. Once the final remediation goals are achieved, the cancer risks, for all sites, will be reduced to $9 \times 10^{-6}$ and the $\mathrm{HI}$ will be reduced to 2 .

\subsection{Attainment of Applicable or Relevant and Appropriate Requirements of Environmental Laws (ARARs)}

The selected remedies will comply with ARARs of federal and state of Alaska environmental and public health laws.

\subsubsection{Applicable or Relevant and Appropriate Requirements (ARARs)}

The remedy chosen for each set of sites will comply with all action-, chemical-, and location-specific ARARs. The ARARs are listed in the following sections, and the relationship between them and the five remedial alternatives are listed in Table 29.

\subsubsection{Action-Specific}

Remedial treatment activities will meet the following action-specific ARARs

- state of Alaska Solid Waste Management Regulations (18 AAC 60) for disposal of treated soils

- state of Alaska Wastewater Disposal Regulations (18 AAC 72) for the discharge of industrial wastewater

- state of Alaska Hazardous Waste Regulations (18 AAC 62), for the treatment and disposal of hazardous wastes

- RCRA waste standard 40 CFR 268 Land Disposal Restrictions may be applicable if placement of RCRA hazardous wastes occurs

- $\quad$ RCRA waste standards 40 CFR 264.251 , which specify that waste piles must use a single liner and leachate collection system

- Federal Clean Air Act (42 USC 7401), as amended, in the case of venting of contaminated vapors

- Federal AWQC § 304 and state of Alaska Water Quality Standards (18 AAC 70) for discharges into Garrison Slough (column 4 of Table 32).

\subsubsection{Chemical-Specific}

Remedial treatment activities will meet the following chemical-specific ARARs:

- MCLs and maximum contaminant level goals (MCLs, non-zero maximum contaminant limit goals [MCLGs], and action levels) established under the Safe Drinking Water Act for groundwater that may be used for drinking water supply (40 CFR 141 and 18 AAC 80). These ARARs are listed in column 2 of Table 32. 
- Alaska Water Quality standards for Protection of Class (1)(A) Water Supply, Class (1)(B) Water Recreation, and Class (1)(C) Aquatic Life and Wildlife (18 AAC 70)

Hardfill Lake is an old gravel pit, excavated to a depth below the groundwater table. The lake is within the ST10 and SS14 source areas and serves as a barrier against migration of contamination out of the immediate area. After closeout of ST10 and SS14, Hardfill Lake will be protected in accordance with Alaska Water Quality Standards.

- Alaska Oil Pollution Regulations (18 AAC 75)

Under the Alaska Oil Pollution Regulations, responsible parties are required to clean up oil or hazardous releases. The U.S. Air Force anticipates achieving a cleanup level that is consistent with this regulation and has proposed a calculation of soil cleanup levels based on the findings in the BLRA (U.S. Air Force 1993c) and a methodology using the EPA SESOIL

\begin{tabular}{|c|c|c|c|c|}
\hline Chemical Compound & Groundwater & \multicolumn{2}{|c|}{ Surface Water } & Soil (a) \\
\hline (1) & $\begin{array}{c}(2) \\
\text { Drinking } \\
\text { Water } \\
\mathrm{MCL} \\
(\mu \mathrm{g} / \mathrm{L})\end{array}$ & $\begin{array}{c}(3) \\
\text { AWOC } \\
\text { Aquatic Life } \\
\text { Freshwater } \\
\text { Chronic } \\
(\mu \mathrm{g} / \mathrm{L})\end{array}$ & $\begin{array}{c}\text { (4) } \\
\text { AWOC } \\
\text { Human Health } \\
\text { Fish Consumption } \\
(\mu \mathrm{g} / \mathrm{L})\end{array}$ & $\begin{array}{c}5) \\
\text { Alternative } \\
\text { Cleanup Levels for } \\
\text { Petroleum } \\
\text { Contaminants } \\
(\mu \mathrm{g} / \mathrm{kg}) \\
\end{array}$ \\
\hline Benzene & 5 & $5300(\mathrm{~b})$ & 40 & 0.2 \\
\hline Toluene & 1000 & $17,500(b)$ & 424,000 & 80 \\
\hline Ethylbenzene & 700 & $32,000(b)$ & 3,280 & 140 \\
\hline Xylenes & 10,000 & & & 760 \\
\hline Naphthalene & & 620 & & \\
\hline Lead & $15(c)$ & 1.3 & & \\
\hline $\begin{array}{l}\text { (a) Soil cleanup levels } \\
\text { calculate these value } \\
\text { (b) Freshwater acute } \\
\text { (c)EPA has establishe }\end{array}$ & $\begin{array}{l}\text { ere establishe } \\
\text { s from Ander } \\
\text { terion, there } \\
\text { an action lev }\end{array}$ & $\begin{array}{l}\text { protect ground } \\
\text { 1992). } \\
\text { freshwater ch } \\
15 \mu \mathrm{g} / \mathrm{L} \text { for lea }\end{array}$ & $\begin{array}{l}\text { from leachate. } \\
\text { criterion for thes } \\
\text { drinking water. }\end{array}$ & $\begin{array}{l}\text { model used to } \\
\text { ompounds. }\end{array}$ \\
\hline
\end{tabular}

and AT123D models (Anderson 1992). The proposed soil cleanup levels are based on protecting groundwater in accordance with drinking water standards.

- Alaska Regulations for Leaking Underground Storage Tanks (18 AAC 78)

Under the Alaska regulations for remediation of contaminated soils and the regulations for cleanup of petroleum releases from underground storage tanks, the ADEC regional supervisor has the authority to determine the level of cleanup that is appropriate for site-specific conditions. The regional supervisor may identify alternative cleanup standards based on the potential for leaching to groundwater. In accordance with this requirement, alternative soil cleanup standards have been calculated (column 5 of Table 28) based on the findings in the BLRA (U.S. Air Force 1993c) and a 
methodology using the EPA SESOIL and AT123D models (Anderson 1992). The soil cleanup levels are based on protecting groundwater in accordance with drinking water standards (Appendix D of the BLRA [U.S. Air Force 1993c]).

\subsubsection{Location-Specific}

None.

\subsubsection{Information To-Be-Considered}

The following information to-be-considered will be used as a guideline when implementing the selected remedy:

- state of Alaska Interim Guidance for Non-UST (underground storage tank) Contaminated Soil Cleanup Levels (July 17, 1991)

- state of Alaska Guidance for Storage, Remediation, and Disposal of Non-UST Petroleum Contaminated Soils (July 29, 1991)

- state of Alaska Interim Guidance for Surface and Groundwater Cleanup Levels (September 26, 1990).

\subsection{Cost Effectiveness}

The selected remedy is cost effective because it has been determined to provide overall effectiveness proportionate to its costs and duration for remediation of the contaminated soils and groundwater. Although the 30-year present worth of $\$ 3,000,000$ for ST10 and SS14 and $\$ 10,700,000$ for ST13 and DP26 is greater than Alternatives 1, 2, and 3, the benefits for Alternative 4 include 1) aggressive treatment of the source of groundwater contamination through implementation of SVE and air sparging systems, 2) it addresses a larger area of contamination, 3 ) it includes active skimming of floating fuel and groundwater treatment at ST13 and DP26, and 4) it is expected to require less time to meet final remediation goals than these other alternatives because it treats a larger source volume. These remedial actions will actively reduce the source of VOC-contaminated groundwater.

Alternative 4 is less expensive than Alternative 5 at both sets of sites. Alternative 4 is cost effective because 1) it is expected to require less time to meet final remediation goals, 2) it treats a larger area of soil contamination, 3 ) it uses an equally comprehensive approach for the removal of floating fuel, and 4) Alternative 5 is not readily implementable because it may require demolition of existing fuel delivery systems.

Alternative 5 requires excavation and treatment of VOC-contaminated soils. Limited amounts of contaminated soils are available for excavation because of the existing fueldelivery infrastructure whose current and future activity is required to fulfill Eielson AFB's primary national security mission. At ST10 and SS14, Alternative 4 would remediate an estimated 120,000 cubic yards of soil; Alternative 5 would excavate an estimated 6,700 cubic yards of soil. At ST13 and DP26, Alternative 4 would remediate an estimated 47,000 cubic yards of soil; Alternative 5 would excavate an estimated 660 cubic yards of soil.

Alternative 5 would only use active skimming for the removal of floating fuel, and it is estimated that $50 \%$ or less of this material can be extracted with this technology. 
Alternative 4 would not only include skimming (active and passive), but it would also use bioventing, SVE, and air sparging to enhance the remediation of the floating fuel layer.

A complete excavation of the contaminated subsurface soils within the smear zone was proposed as an alternative in the draft OU2 FS (U.S. Air Force 1992) for both set of sites. In order to effectively remediate the source of groundwater contamination, it was assumed that all structures at the four sites would be demolished. A detailed analysis for these alternatives were conducted, and the estimated minimum cost for ST10 and SS14 was $\$ 39,000,000$; the estimated minimum cost for ST13 and DP26 was $\$ 16,100,000$.

Because of the high estimated costs and the requisite demolition of active fuel delivery systems, these excavation alternatives were not considered implementable, and the scope of excavation was reduced for the final OU2 FS (U.S. Air Force 1993d).

The remedial systems that will be implemented in Alternative 4 will be implemented in phases, based on actual conditions observed in the field through the monitoring of groundwater, VOC-contaminated soils, and the floating fuel layer. The estimated costs for the implementation of Alternative 4 have been revised downward since the development of the OU2 Proposed Plan and completion of the public comment period (Table 33). The initial construction cost estimate for Alternative 4 was revised from $\$ 5,150,000$ to $\$ 1,700,000$ for ST10 and SS 14; it was revised from $\$ 3,500,000$ to $\$ 2,200,000$ for ST13 and DP26. The total cost estimate for Alternative 4 was revised from $\$ 7,400,000$ to $\$ 3,000,000$ for ST10 and SS14; it was revised from $\$ 12,500,000$ to $\$ 10,700,000$ for ST13 and DP26. In addition, the revised costs are better constrained than those reported in the Proposed Plan (U.S. Air Force 1993i). The revised costs are discussed in Section 11.0 of this ROD. This revision is based on recent results from Eielson AFB onsite experience with cleanup activities. Recent Eielson AFB site experience indicates that remedial technologies can be implemented at a lower capital cost than that calculated in the OU2 FS (U.S. Air Force 1993d) without changing the basic remedial technologies and still achieving the remedial goals listed in Tables 27 and 28.

\subsection{Utilization of Permanent Solutions and Alternative Treatment Technologies to the Maximum Extent Practicable}

The U.S. Air Force, the state of Alaska, and EPA have determined that the selected remedies represent the maximum extent to which permanent solutions and treatment technologies can be used in a cost-effective manner at the OU2 sites. Of those alternatives that are protective of human health and the environment and comply with ARARs, the U.S. Air Force, the state of Alaska, and EPA have determined that the selected remedies provide the best balance of tradeoffs in terms of long-term effectiveness and permanence, reduction in toxicity, mobility, or volume achieved through treatment, short-term effectiveness, implementability, cost (as discussed in the preceding section), and the statutory preference for treatment as a principal element and considering State and community acceptance.

Alternative 4 would aggressively treat the source of VOC groundwater contamination, VOC-contaminated subsurface soils, and floating fuel. The VOC-contaminated groundwater would be allowed to remediate by source reduction; lead contamination will be actively remediated by extraction and treatment. Alternative 5 would remediate the soil contamination by removal and treatment; however, it will not treat as large a volume of soil. Large volumes of contaminated soils could not be excavated because of existing base fuel storage and delivery systems. The remaining soil contamination would be allowed to slowly move through the soil to the groundwater, where it would be pumped out and treated. Alternative 5 would remove floating fuel only through active skimming, an option that is unlikely to remove more than half of this material. Furthermore, although 
groundwater extraction and treatment is a commonly used technology, its effectiveness in achieving groundwater cleanup standards is not well established.

Alternatives 4 and 5 would result in the greatest reduction in toxicity, mobility, and volume of contamination by treating or removing VOC-contaminated soils and floating fuel. Alternative 4 is expected to be more effective. However, Alternative 4 does not actively treat VOC-contaminated groundwater, except for lead-contaminated groundwater at ST13 and DP26. Alternative 5 does actively reduce VOC-contamination through extraction and treatment. Alternatives 1 through 3 do not treat the source of groundwater contamination as aggressively as Alternatives 4 and 5. All alternatives rely on Hardfill Lake to prevent migration of the groundwater contamination at ST10 and SS14; the volume of the groundwater plume at ST13 and DP26 will be monitored.

Alternative 4 would be expected to cleanup the soils in the shortest amount of time, thus eliminating the source of groundwater contamination. In addition, by treating lead contamination in the groundwater at ST13 and DP26, Alternative 4 will reduce the time necessary to achieve groundwater cleanup standards. Alternative 5 would require much more time than Alternative 4 to achieve soil cleanup because of the inability to excavate all of the contaminated soils. Although Alternative 5 would include more extensive groundwater extraction and treatment, it is questionable whether groundwater treatment would be able to achieve cleanup standards faster than natural processes because of the large amounts of remaining soil contamination that could continue to contaminate the groundwater. Alternatives 1,2, and 3 would provide much less short-term effectiveness than the other alternatives.

All alternatives would use readily available technologies and would be feasible to construct. Alternatives 1 and 2 would be readily implementable; they require no additional remedial action. The technologies in Alternative 3 are relatively limited in scope and would also be readily implementable. Several of the technologies in Alternative 4 for the removal of petroleum contamination (bioventing, SVE, and skimming) are being implemented at three other fuel-contaminated areas at Eielson AFB. The results to date suggest that two of the technologies are effective, bioventing (Battelle 1994) and SVE (EA 1994). Skimming for fuel has only been successful at one of four demonstrations (EA 1994). Alternative 5 would be difficult to implement effectively because it is not possible to excavate large volumes of contaminated soils near pipelines, tanks, or operating systems.

The most decisive factors in the selection decision were long-term effectiveness and implementability. Alternative 4 provides the best option for effective remediation of ST10, SS14, ST13, and DP26 in light of the constraints presented by active base fuel supply operations.

\subsection{Preference for Treatment as a Principal Element}

By treating the source of VOC-contaminated groundwater and actively treating leadcontaminated groundwater (ST13 and DP26 only), the selected remedies address the principal source of threats posed by the sites through the use of treatment technologies. Therefore, the statutory preference for remedies that employ treatment as a principal element is satisfied. 


\subsection{Explanation of Significant Differences}

The estimated costs for the implementation of Alternative 4 have been revised downward since the development of the OU2 Proposed Plan (U.S. Air Force 1993i) and completion of the public comment period. The initial construction cost estimate for Alternative 4 was revised from $\$ 5,150,000$ to $\$ 1,700,000$ for $\$ T 10$ and $S S 14$; it was revised from $\$ 3,500,000$ to $\$ 2,200,000$ for ST13 and DP26. The total cost estimate for Alternative 4 was revised from $\$ 7,400,000$ to $\$ 3,000,000$ for $\$ T 10$ and SS14; it was revised from $\$ 12,500,000$ to $\$ 10,700,000$ for ST13 and DP26. In addition, the revised costs are better constrained than those calculated in those reported in the OU2 Proposed Plan. This revision is based on recent results from Eielson AFB onsite experience with cleanup activities. Recent Eielson AFB site experience indicates that remedial technologies can be implemented at a lower capital cost than that calculated in the OU2 FS (U.S. Air Force 1993d) without changing the basic remedial technologies and still achieving the remedial goals listed in Tables 27 and 28.

The revised costs were calculated using the same methodologies and contingencies as those in the FS (U.S. Air Force 1993d) that are reported in Table 31 of this ROD.

Recent field experience indicates that bioventing will be more effective in remediation than was initially assumed during the preparation of the OU2 final FS and Proposed Plan. Thus, bioventing/SVE will be the primary remedial technologies. If these systems do not prove to be effective in attaining final remedial goals, then an air sparging system may be implemented as part of the phased approach. The updated cost estimate retained the implementation of air sparging as a contingency. Its scope, however, is greatly reduced. The updated cost estimate assumes that air sparging will be implemented where the apparent thickness of floating product exceeds 1 foot. This reduces the number of wells at ST10 and SS14 from 350 to 60 . The number of wells at ST13 and DP26 is reduced from 15 to 4 .

Additional changes in assumptions that went into these new calculations for capital costs are

- no treatment of gases extracted by the SVE system

- deletion of a second control building

- deletion of the asphalt cap

- no hydraulic containment for groundwater at ST13 and DP26

- reduction in well costs from $\$ 2000$ to $\$ 1500$ per well.

The primary changes in operations and maintenance costs are

- no maintenance of asphalt cap

- no maintenance of hydraulic containment at ST13 and DP26

- groundwater monitoring at ST10 and SS14 will cease after 10 years, once remediation is complete.

The assumptions for several of these changes are different from those described in the OU2 FS (U.S. Air Force 1993d). Off-gas treatment, installation of asphalt caps, and hydraulic containment at ST13 and DP26 were all included within the selected remedies in the FS. Technical data that have been gathered since preparation of the FS indicate that off-gas treatment and asphalt caps have not proven necessary in SVE cleanups in the Fairbanks area of Alaska, and 1992 field data suggest that the groundwater contaminant plume at ST13 and DP26 is receding in size. 
The resulting costs listed in this section are lower than those initially calculated and reported in the Proposed Plan (U.S. Air Force 1993i); thus, the selected remedies are even more cost effective than originally estimated.

\subsection{References}

Anderson. 1992. Development of Generic Soil Cleanup Levels Based on Analysis of the Leachate Pathway. Environmental Cleanup Division, Oregon Department of Environmental Quality, May 12.

Battelle. 1992. Remedial Investigation/Feasibility Study -- Operable Units 3, 4, and 5 Management Plan. Eielson Air Force Base, Alaska. Battelle, Environmental Management Operations, Richland, Washington (Final).

Battelle. 1994. Bioremediation of Hazardous Wastes at CERCLA and RCRA Sites: Eielson AFB Site. Project Report, Battelle, Columbus, Ohio.

Cederstrom, D.J. 1963. Ground-Water Resources of the Fairbanks Area. Alaska. U.S. Geological Survey Water-Supply Paper 1590.

Clement Associates. 1988. Comparative Potency Approach for Estimating the Cancer Risk Associated with Exposure to Mixtures of Polycyclic Aromatic Hydrocarbons. Interim Final Report, Clement Associates, Fairfax, Virginia.

CH2M Hill. 1982. Installation Restoration Program Records Search for Eielson Air Force Base, Alaska. CH2M Hill, Gainesville, Florida.

Dames and Moore. 1985. Installation Restoration Program Phase II Confirmation/Quantification Stage 1 First Draft Report for Eielson Air Force Base, Alaska, Alaskan Air Command. Prepared by Dames \& Moore for the U.S. Air Force Occupational and Environmental Health Laboratory, Brooks Air Force Base, Texas, February 28.

EA. 1994. "OU1B Interim Remedial Action, Outline Summary of Work at Source Areas ST-20 (E-7), ST-20 (E-9), ST-48, ST-49, and SS 50-52 during 1991 and 1993." Letter Report, EA Engineering, Science, and Technology, February 25, 1994.

Eielson AFB. 1992. Eielson Air Force Base Comprehensive Landuse Plan. Eielson Air Force Base, Fairbanks, Alaska.

EPA. 1984. "Summary of Current Acceptable Daily Intakes (ADIS) for Oral Exposure." Environmental Criteria and Assessment Office, Cincinnati, Ohio.

EPA. 1988. Guidance for Conducting Remedial Investigations and Feasibility Studies under CERCLA. OSWER Directive 9355.3-01, U.S. Environmental Protection Agency, Office of Emergency and Remedial Response, Washington, D.C. (Interim Final).

EPA. 1991a. Supplemental Guidance for Superfund Risk Assessments in Region 10.

U.S. Environmental Protection Agency, Seattle, Washington. 
OU-2 Record of Decision

Eielson Air Force Base

EPA. 1991b. Health Effects Assessment Summary Tables. PB91-921199, U.S.

Environmental Protection Agency, National Technical Information Service, Springfield, Virginia.

EPA. 1992a. Health Effects Assessment Summary Tables. NTIG/PB92-921199, U.S. Environmental Protection Agency, National Technical Information Service, Springfield, Virginia.

EPA. 1992b. Integrated Risk Information System (IRIS) (Online). U.S. Environmental Protection Agency, Office of Health and Environmental Assessment, Environmental Criteria and Assessment Office, U.S. Environmental Protection Agency, Cincinnati, Ohio.

EPA, ADEC, and U.S. Air Force. 1991. Eielson AFB Federal Facility Agreement under CERCLA Section 120, EPA Docket Number: 1089-07-14-120.

HLA. 1989. Installation Restoration Program Remedial Investigation/Feasibility Study Stage 3, Eielson Air Force Base, Draft Remedial Investigation/Feasibility Study, Volume II (July 1988 to April 1989). Harding Lawson Associates.

HLA. 1990. Installation Restoration Program Remedial Investigation/Feasibility Study, Stage 4, Draft Remedial Investigation/Feasibility Study, Volumes I through V. Harding Lawson Associates, Anchorage, Alaska.

HLA. 1991. Installation Restoration Program Remedial Investigation/Feasibility Study Stage 4, Draft Remedial Investigation/Feasibility Study, Volumes VII through XVIII. Harding Lawson Associates, Anchorage, Alaska.

Krumhart, A. P. 1982. Hydrologic Information for Land-Use Planning, Badger Road Area, Fairbanks, Alaska. Water-Resources Investigation 82-4097. U.S. Geological Survey.

Nelson, G. 1978. Hydrologic Information for Land-Use Planning, Fairbanks Vicinity. Alaska. U.S. Geological Survey.

SAIC. 1989. U.S. Air Force Installation Restoration Program Remedial Investigation/Feasibility Study of the Fuel Saturated Area at Eielson Air Force Base, Alaska: Remedial Investigation Report. Volumes I, II, and III. Science Applications International Corporation (Draft).

U.S. Air Force. 1992. Eielson Air Force Base OU-2 Remedial Investigation/Feasibility Study: Baseline Risk Assessment, Battelle, Environmental Management Operations, Richland, Washington (Draft).

U.S. Air Force. 1993a. Eielson Air Force Base OU-2 Remedial Investigation/Feasibility Study: Remedial Investigation Report. Battelle, Environmental Management Operations, Richland, Washington (Final).

U.S. Air Force. 1993b. Eielson Air Force Base OU-2 Remedial Investigation/Feasibility Study: Remedial Investigation Appendixes, Battelle, Environmental Management Operations, Richland, Washington (Final).

U.S. Air Force. 1993c. Eielson Air Force Base OU-2 Remedial Investigation/Feasibility Study: Baseline Risk Assessment, Battelle, Environmental Management Operations, Richland, Washington (Final). 
U.S. Air Force. 1993d. Eielson Air Force Base OU-2 Remedial Investigation/Feasibility Study: Feasibility Study. Battelle, Environmental Management Operations, Richland, Washington (Final).

U.S. Air Force. 1993e. Background Soil Quality, Eielson Air Force Base, Alaska. Battelle, Environmental Management Operations, Richland, Washington (Final).

U.S. Air Force. 1993f. Background Groundwater Quality. Eielson Air Force Base, Alaska. Battelle, Environmental Management Operations, Richland, Washington (Final).

U.S. Air Force. 1993g. Source Evaluation Report. Phase 1, Eielson Air Force Base, Alaska. Battelle, Environmental Management Operations, Richland, Washington (Final).

U.S. Air Force. 1993h. Site Groundwater Management Plan. Eielson Air Force Base. Alaska. Battelle, Environmental Management Operations, Richland, Washington (Draft).

U.S. Air Force. 1993i. Proposed Plan for Operable Unit 2 and Other Areas. Battelle, Environmental Management Operations, Richland, Washington (Final).

Weddleton, J., H. Richards, and R. Seifert. 1989. Building in Alaska. A Guide for Assessing Risks and Costs of Water Well Drilling in the Fairbanks Area. Cooperative Extension Service, University of Alaska Fairbanks, Fairbanks, Alaska. 


\title{
Source Evaluation Report (SER) Areas
}

\author{
LF05 - Old Army Landfill \\ LF07 - Test Landfill \\ FT08 - Fire Training Area (Past) \\ SS12 - JP-4 Spill, Building 2351 \\ ST15 - Multiproduct Fuel Line \\ ST16 - MOGAS (Motor Gasoline) \\ Fuel Line Spill \\ ST17 - Canol Pipeline Spill \\ SD21 - Road Oiling - Quarry Road \\ SD22 - Road Oiling - Industrial Road \\ SD23 - Road Oiling - Manchu Road \\ SD24 - Road Oiling - Gravel Haul Road \\ DP28 - Fly Ash Disposal Site \\ DP29 - Drum Burial Site \\ SS30 - PCB Storage Facility \\ SS31 - PCB Storage Facility \\ DP40 - Power Plant Sludge Pit \\ SS41 - Auto Hobby Shop (Past) \\ SS42 - Miscellaneous Storage \\ and Disposal Area \\ SS47 - Commissary Parking Lot \\ Fuel Spill \\ WP60 - New Auto Hobby Shop \\ SS62 - Garrison Slough
}

\section{OU2 Source Areas}

ST10 - E-2 POL Storage

ST11 - Fuel Saturated Area

ST13 - E-4 Diesel Fuel Spill

SS14 - E-2 Railroad JP-4 Fuel Spill

ST18 - Oil Boiler Fuel Spill

ST19 - JP-4 Fuel Line Spill

DP26 - Fuel Tank Suldge Burial Site

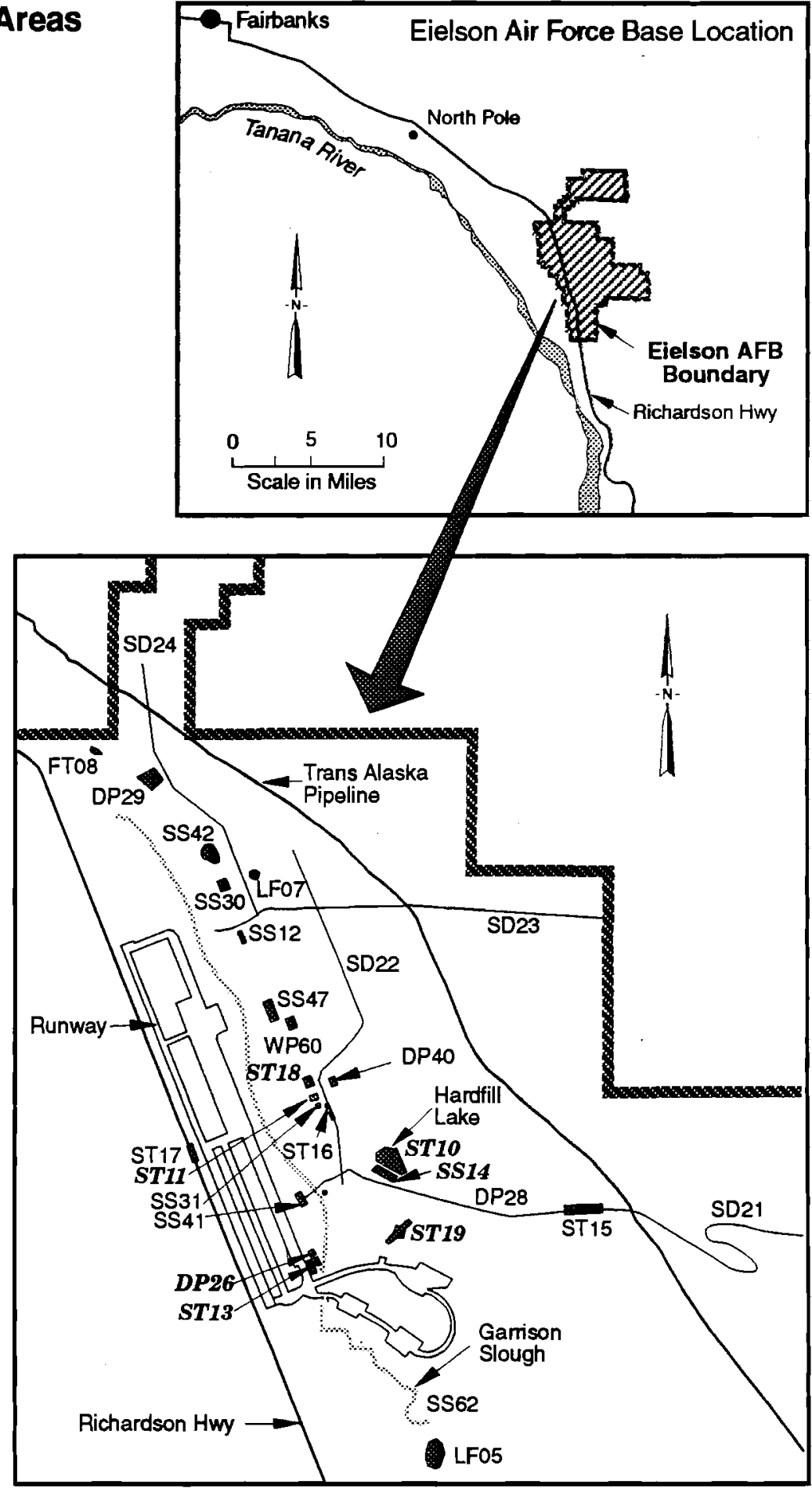

Figure 1. Location Map of Eielson Air Force Base 
$\rightarrow$ 


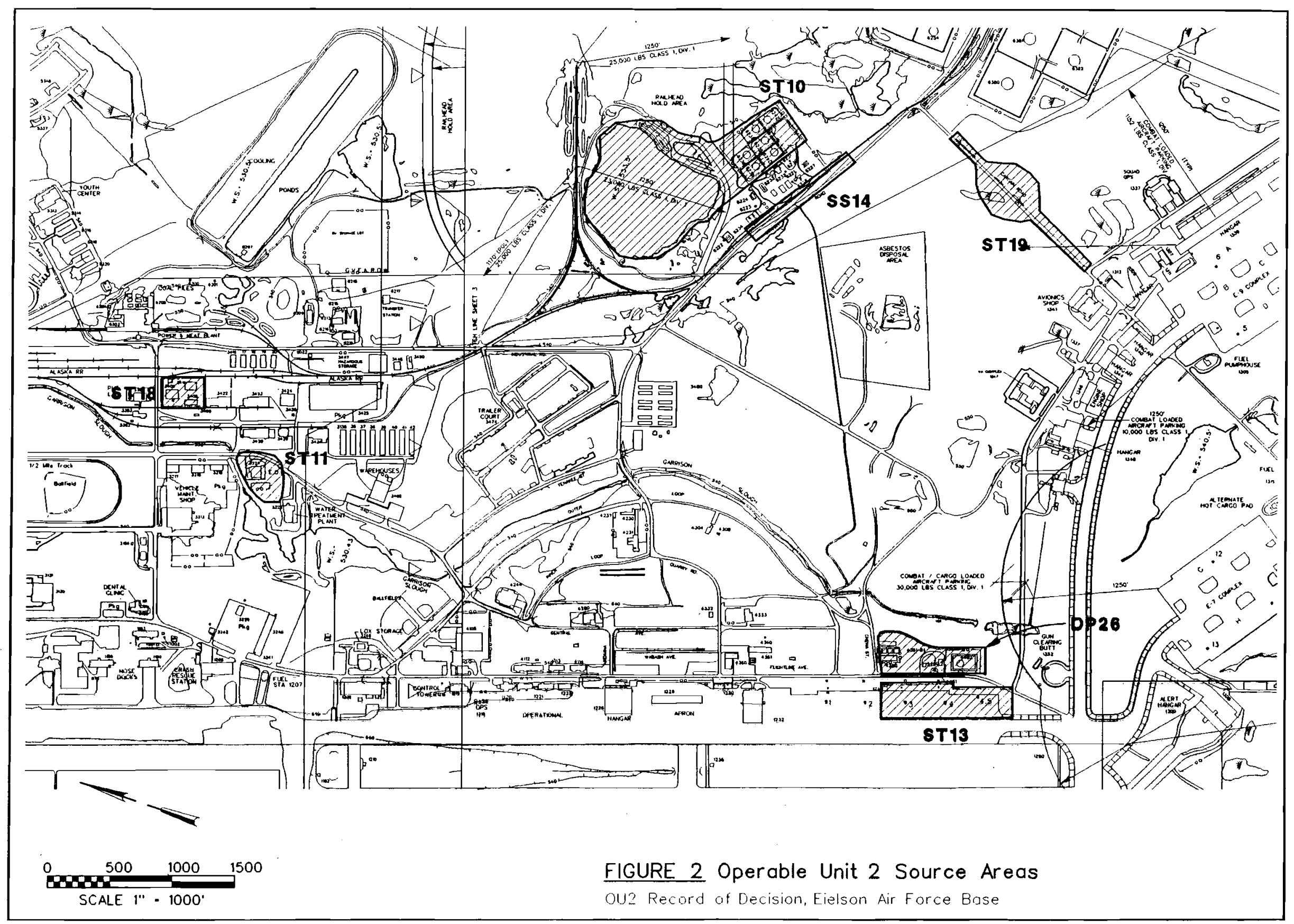

UNIT2SC $\cap$ NN 



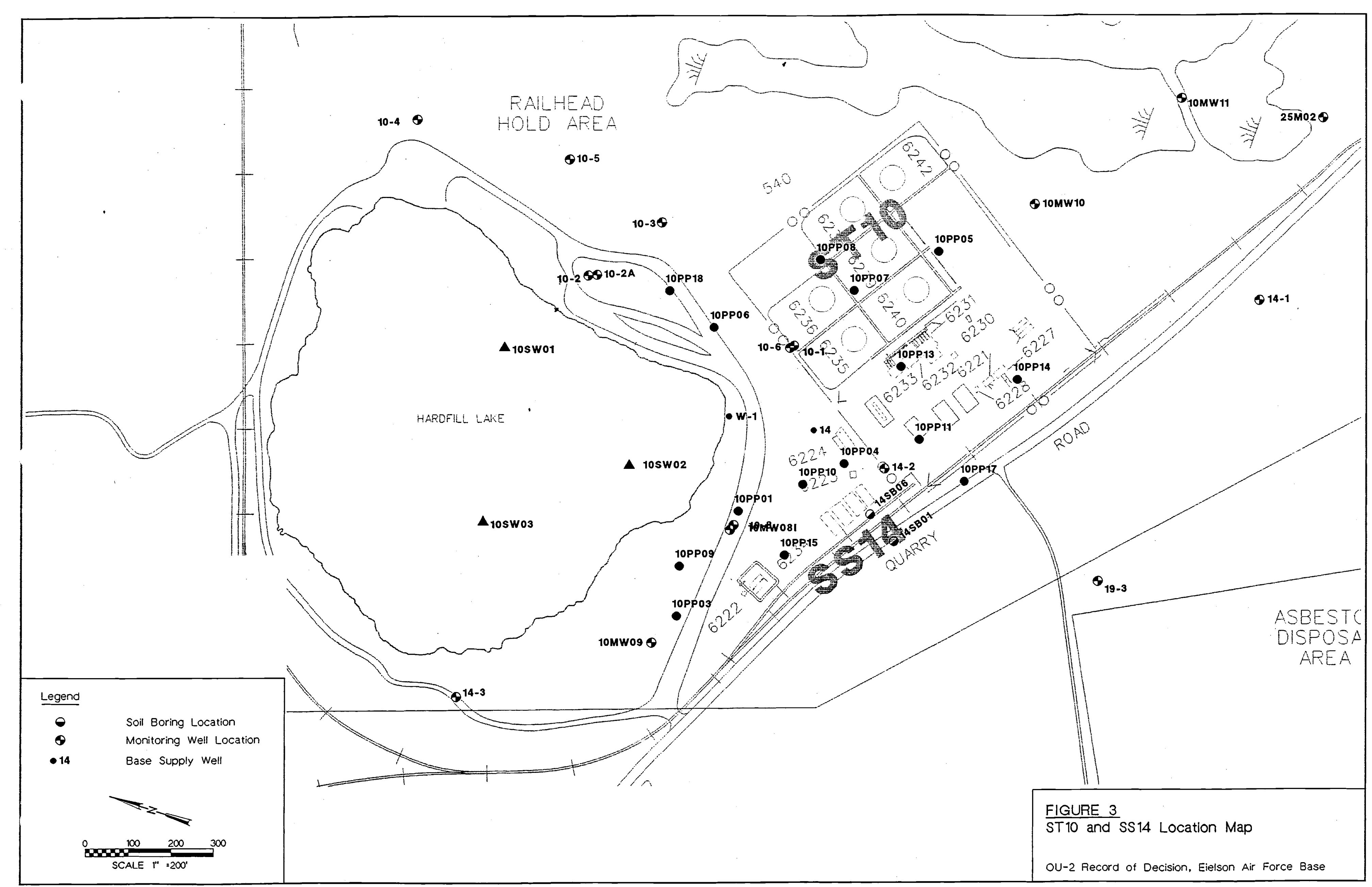




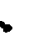




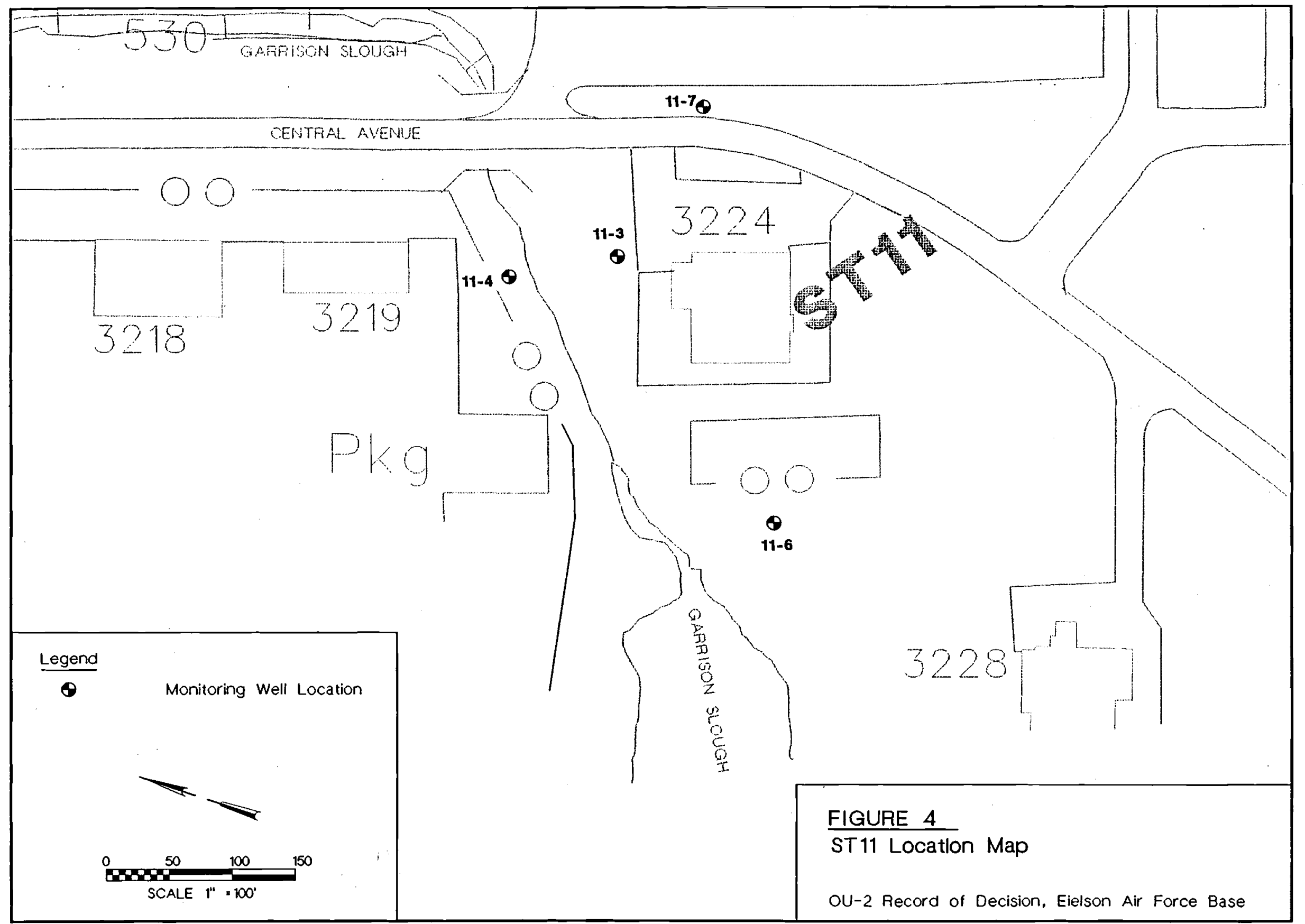

NAME:OU206.DGN 


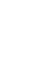









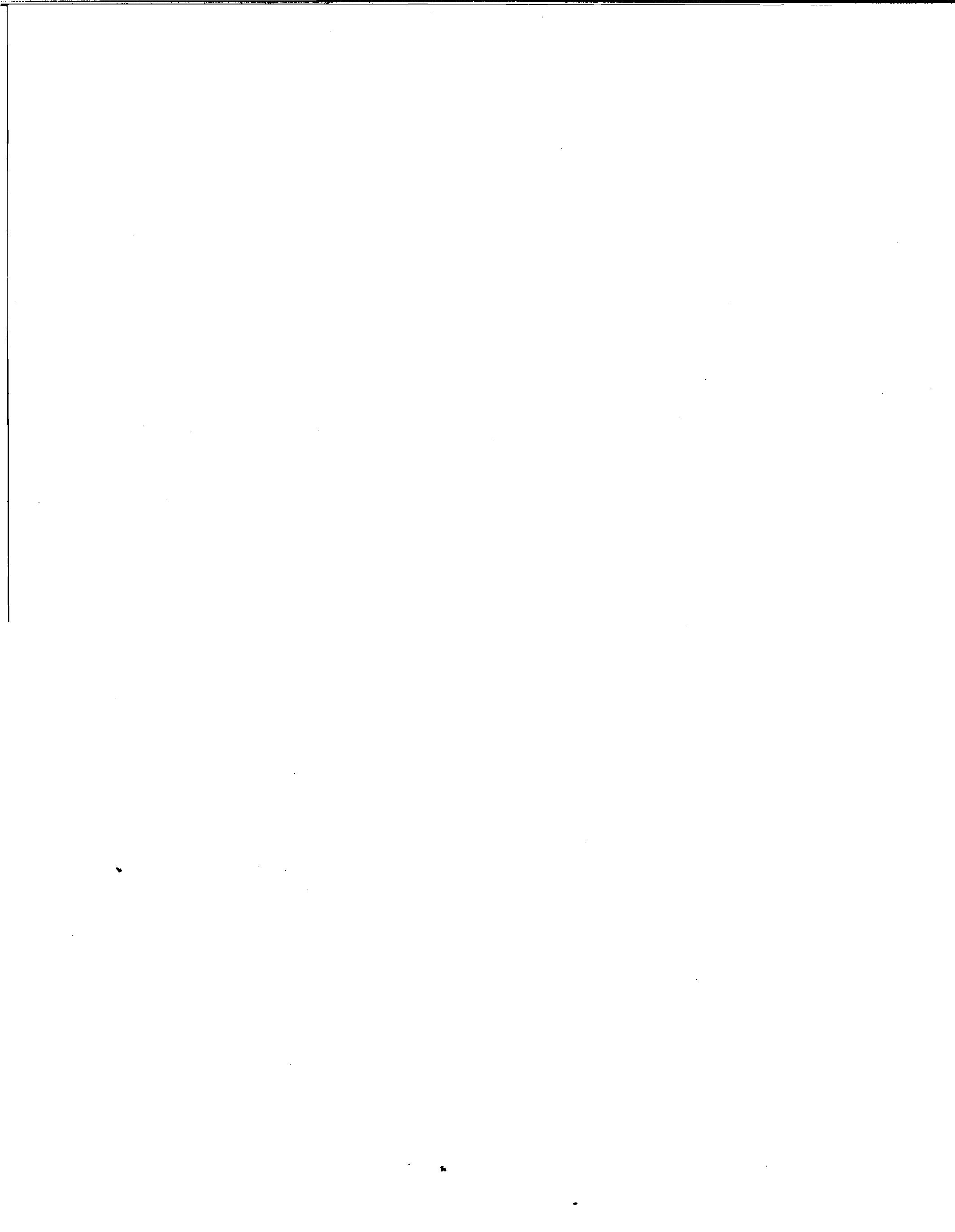

|

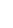




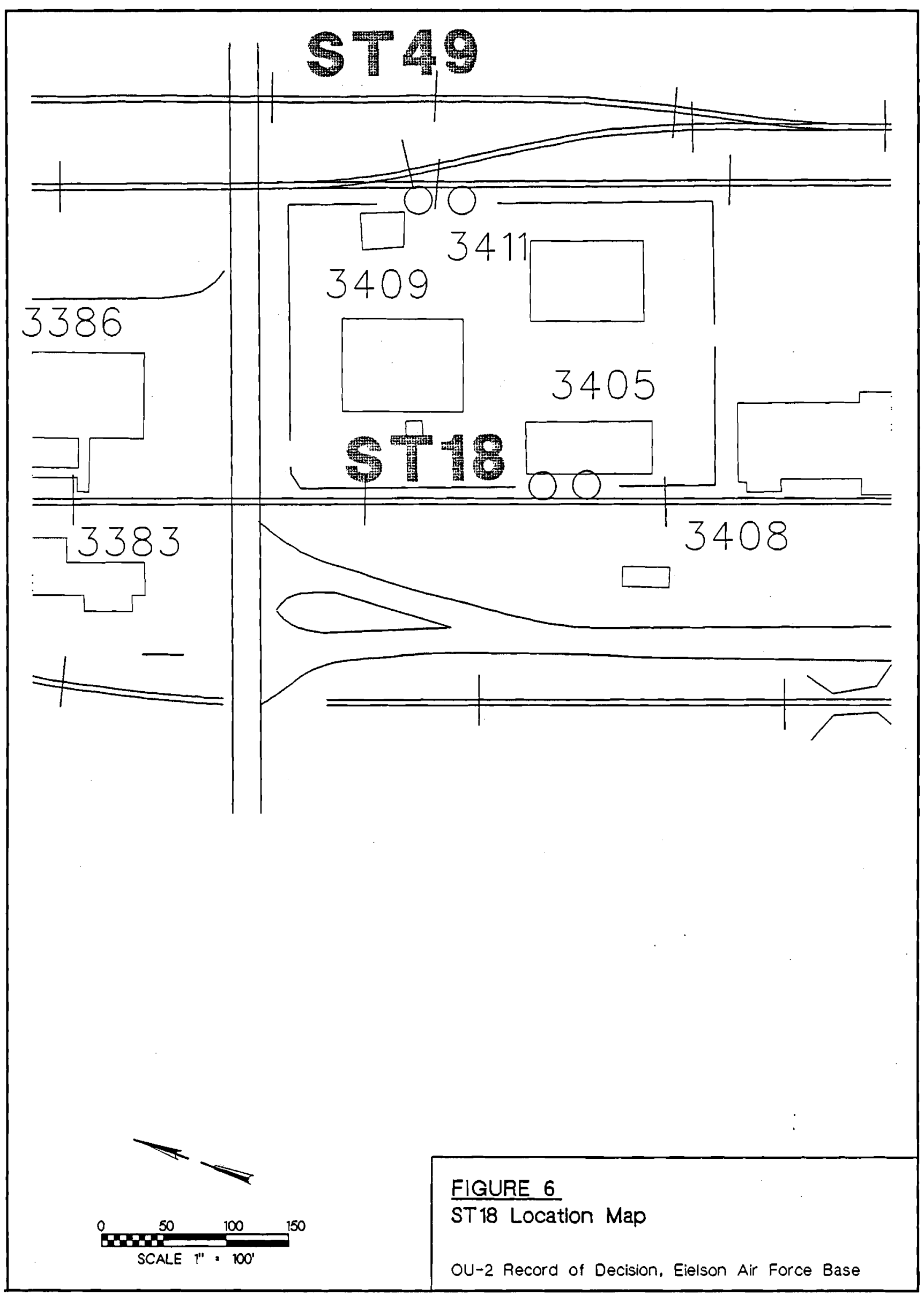




\section{Eielson Air Force Base Operable Unit 2 and Other Areas Record of Decision}

\section{Responsiveness Summary}

\section{A. Overview}

The joint cleanup decision preferred by the U.S. Air Force, Alaska Department of Environmental Conservation (ADEC), and U.S. Environmental Protection Agency (EPA) was presented to the public in a Proposed Plan (U.S. Air Force 1993i) and discussed in a public meeting on November 17,1993 . This plan proposed that three of the Operable Unit 2 (OU2) sites (ST11, ST18, and ST19) and all of the source evaluation report (SER) sites discussed would require no further remedial action. All were found to not pose an unacceptable risk to human health and the environment. Remedial action was proposed for the remaining four OU2 sites (ST10, SS14, ST13, and DP26). The preferred cleanup method, Alternative 4 of the OU2 Feasibility Study (FS) (U.S. Air Force 1993d), would use a combination of bioventing, soil vapor extraction, air sparging and groundwater treatment (at two sites for lead) employed in a phased approach. The guiding principle for this alternative was to perform in situ treatment of the fuel-contaminated soil and a floating fuel layer in order to halt continued groundwater contamination.

Public comments in response to the Proposed Plan and public meeting ranged from solid support of the plan as the best compromise among cleanup options to mild opposition against several of the no further action (NFA) proposals. A few residents wanted more excavation, but none wanted to delay the process. Treating the source of continuing contamination (fuel-saturated soil) was supported as a good way to proceed at OU2, and some suggested the same methods should be applied at some of the fuel-contaminated SER source areas as well, even though the risk was within the acceptable levels.

\section{B. Background on Community Involvement}

Pursuant to the signing of the Federal Facilities Agreement (FFA) (EPA et al. 1991) with the State of Alaska and the EPA, the U.S. Air Force began its Superfund cleanup program. As part of this program, in accordance with Comprehensive Environmental Response, Compensation, and Liability Act (CERCLA) Sections 113(k)(2)(B)(i-v) and 117, an extensive community relations program was initiated to involve the community in the decision making process.

The primary means for public involvement was through a public notice period and a public meeting. The Proposed Plan for OU2 was advertised twice in two local papers. The public comment period and public meeting were advertised on November 12 in the Goldpanner base paper. A 9-inch display ad that highlighted the cleanup efforts was placed in the North Pole Independent on November 5 and 12, and in the Fairbanks Daily News Miner on November 5,15, and 16. In addition, more than 3,500 copies were added as an insert in the base newspaper and delivered to every home in the Eielson Air Force Base (AFB) housing area. A news release announcing the Proposed Plan and public meeting was sent to all local news media (radio, television, newspapers) and the story ran on the 
front page of the base newspaper. The meeting was advertised on the base access cable channel and in the base information bulletin as well as at least one local area radio station. The base First Sergeants Group (the senior enlisted leadership for each unit on base) was briefed on the plan and public meeting to encourage their people to attend. Copies of the plan were delivered to various information repositories, plus the North Pole City Hall.

As part of the U.S. Air Force Installation Restoration Program (IRP), a Technical Review Committee (TRC) was established in 1992 including three representatives from the community (selected by local officials and the Chancellor of the University of Alaska, Fairbanks), industry representatives, and environmental agency representatives, and in November 1993, a local environmental interest group was invited to participate. Many of the TRC participants are members of the professional public. The Proposed Plan was presented to the TRC on November 16,1993. At this meeting, representatives from the U.S. Air Force, ADEC, and EPA responded to questions from audience representing the University of Alaska, the city of North Pole, and various State and federal agencies.

\section{Summary of Comments Received During the Public Comment Period And Responses}

The public comment period on the OU2 Proposed Plan was held from November 8 until December 7, 1993. It was extended until December 20, 1993, because of a typographical error that required advertising a correction to the plan. Comments received during that period are summarized below. Part I addresses nontechnical concerns, while Part II responds to technical and legal questions. Each part is grouped by similar topics.

\section{PART I Summary and Response to Local Community Concerns}

Topic: Small Contractors Liability Bonding for Long-Term Cleanups

Public Comment \# 1: One person wanted to know if the U.S. Air Force could make a special provision for small or disadvantaged businesses who wish to work on cleanups that could involve a 5- to 10-year effort. Because of the large bond often required in cleanup work, and the considerable period of time this money would be unavailable, many smaller businesses cannot afford this burden and are unable to bid on work for which they are qualified.

Response: Contracting issues are policy decisions set by the Department of Defense. Their policy is to award work only to companies that can insure they can complete a job satisfactorily by putting up a bond. This bond is required to satisfy the public that taxpayers will have recourse in the event of unsatisfactory performance by a contractor. Eielson AFB does not have the authority to alter this requirement. However, most of the cleanup contracts are awarded to large companies who often subcontract to qualified local businesses. Negotiations between these private companies would not be subject to U.S. Air Force bonding requirements.

\section{PART II Response to Specific Technical and Legal Questions}

\section{Topic: Groundwater Characterization}

Public Comment \#2: One person wanted to know the source for drinking water at Eielson AFB: where does the groundwater flow, and what studies have been done on groundwater flow rates and directions?

Response: The drinking water for Eielson AFB is supplied by three groundwater wells. The groundwater is found in spaces in the underground sands and gravels. This water- 
bearing rock formation is 200 to 300 feet thick, and the drinking water is removed from depths of around 100 feet below the surface. The top of the groundwater is typically 8 to 10 feet below the surface.

The direction of groundwater flow at Eielson AFB is generally to the north-northwest. Locally, it is influenced by Garrison Slough, Hardfill Lake, and pumpage of base supply wells. The direction of groundwater flow appears to be fairly constant year-round.

Determination of groundwater flow rate and direction is an important aspect in the investigation of possible environmental hazards at Eielson AFB. Portions of each of the following studies present data on groundwater flow and discuss the results. In addition, some location-specific hydrological information will be collected during the design phase of the remediation projects.

Battelle. 1992. "Raw Data for Calculations of Darcian Flow Velocities at the Eielson Air Face Base." Supplied by Mr. T. Gilmore of Battelle, Pacific Northwest Laboratories, Richland, Washington.

Battelle. 1992. Remedial Investigation/Feasibility Study -- Operable Units 3,4. and 5 Management Plan, Eielson Air Force Base, Alaska. Battelle, Environmental Management Operations, Richland, Washington. (Final).

Battelle. 1992. Remedial Investigation/Feasibility Study -- Operable Unit 2 Baseline Risk Assessment Report, Eielson Air Force Base, Alaska. Battelle, Environmental Management Operations, Richland, Washington. (Draft).

HLA. 1989. Installation Restoration Program Remedial Investigation/Feasibility Study. Stage 3, Eielson Air Force Base. Draft Remedial Investigation/Feasibility Study, Volume II (July 1988 to April 1989). Harding Lawson Associates, Anchorage, Alaska.

HLA. 1990. Installation Restoration Program Remedial Investigation/Feasibility Study, Stage 4, Draft Remedial Investigation/Feasibility Study, Volumes I through

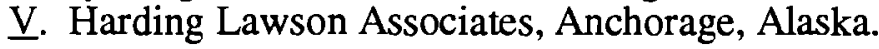

HLA. 1991. Installation Restoration Program Remedial Investigation/Feasibility Study, Stage 4, Draft Remedial Investigation/Feasibility Study, Volumes VII through XVIII. Harding Lawson Associates, Anchorage, Alaska.

SAIC. 1989. U.S. Air Force Installation Restoration Program Remedial Investigation/Feasibility Study of the Fuel Saturated Area at Eielson Air Force Base. Alaska: Draft Remedial Investigation Report, Volumes I, II, and III. Science Applications International Corporation (Draft).

U.S. Air Force. 1993. Eielson Air Force Base OU-2 Remedial Investigation/Feasibility Study: Remedial Investigation Report. Battelle, Environmental Management Operations, Richland, Washington (Final).

U.S. Air Force. 1993. Eielson Air Force Base OU-2 Remedial Investigation/Feasibility Study: Remedial Investigation Appendixes. Battelle, Environmental Management Operations, Richland, Washington (Final).

U.S. Air Force. 1993. Background Groundwater Quality. Eielson Air Force Base, Alaska. Battelle, Environmental Management Operations, Richland, 
Washington (Final).

U.S. Air Force. 1993. Site Groundwater Management Plan. Eielson Air Force Base, Alaska. Battelle, Environmental Management Operations, Richland, Washington (Draft).

All of these documents are available to the public at the following locations:

Elmer E. Rasmusen Library

Arctic and Polar Regions Archives Section

University of Alaska

Fairbanks, AK 99775

(907) 474-6594

Environmental Management Office

Administrative Records

2258 Central Ave, Suite 1

Eielson AFB AK 99702-2225

(907) 377-5209

Comment \#3: Another person stated that groundwater is generally known to flow in a northwesterly direction; however, seasonal and local variation in groundwater flow may occur. Cold, dense groundwater and the interaction of warmer surface waters also appears to impart a vertical groundwater flow component that can affect the horizontal and vertical distribution of contaminants. Migration of contaminants, especially dense nonaqueous phase liquids (DNAPLs) and benzene, can be affected by localized groundwater flow and show variation in concentrations at various depth zones. Because benzene from fuel releases has been shown to migrate great distances, appropriate groundwater analyses should be performed at all contaminated sites at various depth intervals and distances from the source to provide a complete understanding of contaminant migration. Eielson AFB should demonstrate its comprehensive understanding of the groundwater regimen before any base-wide recommendation on contaminated sites can be proposed that is protective of human health and the environment.

Response: Series of nested wells, wells completed at different depths in the aquifer, were installed at three of the OU2 sites: ST10, ST18, and DP26. Pressure transducers were installed in these wells to determine the vertical gradient at these sites. Any vertical gradient, if present, was less than the error of the transducers and the E-tape used to calibrate the transducers-- most likely 0.01 feet. Much more detail on the measurement of the vertical gradient at Eielson AFB is provided in the following reference:

U.S. Air Force. 1993. Automatic Water Level Measurements, Eielson AFB, Alaska. September 1991 - August 1992. Battelle, Environmental Management Operations, Richland, Washington.

The data suggest that groundwater contamination (e.g., benzene) at OU2 is concentrated in the upper part of the unconfined aquifer. This conclusion is consistent with the very low vertical gradient and the presence of contaminants that have densities less than water.

No DNAPLs were recognized at the OU2 sites; none were expected because the sources of contamination at these sites are leaks and spills of fuels.

The concentrations of organic contaminants (including benzene) were measured in all of the groundwater monitoring wells at the OU2 sites, including those completed at intermediate depths ( 30 to 50 feet below the ground surface) and at greater depths ( 58 to 68 feet at 
DP26, 96 feet at ST10). These intermediate wells were completed where the shallow groundwater was contaminated with BTEX. No groundwater contamination was detected in the nested wells at ST18. Benzene was detected in one of the intermediate wells at ST10 at a level below its maximum contamination limit (MCL); benzene was detected in the intermediate well at DP26 at a level greater than its MCL. No other contaminants were detected in the intermediate wells. No contaminants were detected in the two deep wells. A summary of the data will be provided to the commenter.

\section{Topic: SER Sites}

Comment \#4: One person had a number of comments on the number of samples collected at DP40 (Power Plant Sludge Pit). This person suggested that additional samples should be taken at DP40 before the site is placed in the no further action category. Rationalizing reasons to close it is not good enough. A follow-up telephone call indicated that the concern is with leaching metals out of the boiler walls during acid removal of scale. Response: Recent actions have occurred at this site. Sludge dredged from the pond is currently being tested and will be disposed of in accordance with the laboratory results and State and federal regulations. Permitted discharges to the pond may occur in the future. Accordingly, this site will be closed as a Comprehensive Environmental Response, Compensation, and Liability Act (CERCLA) site and evaluated under Resource Conservation and Recovery Act (RCRA) for appropriate action. For additional information on the status of this site, please call the Environmental Compliance Office, Eielson AFB, at (907) 377-1697.

Comment \#5: The plan references petroleum, oil, and lubricant (POL) spills from various sites (SS12, ST15, ST16) totaling 20,000 gallons. What is not known is the potential for unreported spills or releases from these facilities of lesser quantities. No or little sampling was performed to establish the presence or absence of contamination present in the environment. Contaminated soils were encountered at the Commissary parking lot (SS47) from an apparently unknown source. Provide justification for no sampling and analysis from known release sites when fuel contamination was encountered from an unknown source. It appears that a complete understanding of contamination at these sites is not fully understood. The source of the unknown petroleum and lead contamination at the Commissary parking lot warrants further evaluation.

Response: The potential for unreported historical releases does exist; however, a review of past activities has been conducted by consultants as part of the base IRP. Sampling under the site-wide groundwater monitoring program has not indicated the presence of unreported spills. A final site-wide monitoring plan is being developed that will also serve to identify additional source areas if they do exist.

In addition, we are continuing to seek validation of the review results through public input. Specifically, we sent out over 3,500 copies of the Proposed Plan to members of the base and surrounding community for public comment and to seek any additional information about conditions at the site. To date, no additional information of other reported spills has been received.

Soil or groundwater samples were not collected at SS12; however, samples were collected at ST15 and ST16 and summarized in the Phase I SER report (U.S. Air Force 1993a). Confirmatory sampling is planned for ST16.

The Proposed Plan states that lead was detected in groundwater in two wells on the southern portion of the Commissary parking lot. Since that time, both wells were resampled and found to contain only background (natural) concentrations of lead. 
Comment \#6: It appears from the description in the plan that sampling at Building 6214 (ST16) was not conducted because of the apparent absence of spilled solvents, although paint spills were apparently noted. What is the basis for not sampling soil and groundwater even though paint stains are noted?

Response: There were several reasons for not sampling in the vicinity of Building 6214 . First, during a site inspection, U.S. Air Force and ADEC personnel could detect no major spills or leaks as would be indicated by staining of soils where the drums were stored. Small deposits of tar or asphalt and several small paint spills were found. These materials are typically found around any area where asphalt parking lots and roads have been constructed or buildings are painted. They are only incidental debris and do not represent or indicate that a significant contaminant release has occurred. Second, Well 16-2 is downgradient of the site. Water samples from this well do not contain solvents or any other constituents above MCLs. Therefore, the decision was made not to sample this area.

Additional sampling is planned for this site, however. The Phase I SER (U.S. Air Force 1993a) states that "Although ST16 is recommended for no further action, supplemental soil sampling will be performed in the vicinity of Building 6214 during 1994 to confirm that no significant contamination remains. Groundwater beneath the site will continue to be monitored as part of a sitewide groundwater monitoring program."

Comment \#7: The plan does not adequately summarize the background information for the Phase I Source Evaluation to allow for comment on the appropriateness of a NFA recommendation. Although the baseline data are available, it is not possible to provide a reasonable response to the appropriateness of a NFA. Additional site evaluations should be conducted under State guidance. In a follow-up telephone call, the commenter stated that it would be difficult to find the time to review the reports and determine if the data actually support the NFA conclusions. The commenter was concerned about the overall tone of the plan, which suggested that the U.S. Air Force had investigated the sites with a minimum of sampling and that the public should trust that the right decisions had been made. The commenter was also concerned whether the U.S. Air Force was being held to the same cleanup standards required by the State for small operators.

Response: We appreciate this comment and will keep it in mind for future Proposed Plans. We recognize that our justification for NFA on many of the sites became quite brief in our effort to keep the Proposed Plan as concise as possible. In fact, additional sampling is planned for some of the NFA sites, which was not made clear in the Proposed Plan but is mentioned in this Responsiveness Summary. Also, the Phase I SER states that "The groundwater beneath Eielson AFB will continue to be monitored as part of a sitewide groundwater monitoring program. If it is determined that there are contaminant releases to the groundwater originating from any areas recommended for no further action, the potential source of contamination will be re-evaluated. This re-evaluation may include additional sampling and/or source characterization."

ADEC and EPA have been involved in the review and evaluation of the data and decisions regarding the NFA source areas. These decisions are based, in most cases, on field investigations involving sampling of soils, groundwater, and surface water. Some management decisions were made, based on general assumptions, in which ADEC and EPA participated. Ten other SER source areas were reviewed in the same process and found to require additional sampling before a decision could be made as to their disposition. These data, site evaluations, and recommendations are presented in the SER Phase 1 report that ADEC and EPA reviewed and approved. The State has been involved in this process from the start as specified in the Federal Facility Agreement that dictates how the CERCLA process is to be organized at Eielson AFB. 
Comment \#8: Explain how waste petroleum products and waste oils used to control dust on unpaved road surfaces will evaporate during application and be readily dispersed by the wind. I do not dispute that there should be no impact; however, the reason given is not valid.

Response: The commenter is accurate in his implication that road oiling would not be effective if the applied material evaporated. The statement in the proposed plan was not intended to convey this message but to identify several of the common ways in which materials applied to a gravel road can be transported. Some of the volatile components in the road oil mixture will evaporate during application and others will evaporate from the roadbed over time. Nonvolatile components will adhere to the fine-grained road particles and prevent them from being resuspended in the air as dust. Over time and with use of the road, the aggregates of fine particles are broken up and get resuspended in the air as dust and are dispersed by wind to surrounding land.

Comment \#9: If a significant volume of fuel (20,000 gallons) was released offbase from the Canol pipeline, which is used by the U.S. Air Force, should not the U.S. Air Force evaluate the potential for contaminants in the area of this spill?

Response: After some research, it appears the original document (1982) identified this spill erroneously and assigned the spill to the Canol pipeline. The spill should have been assigned to the Haines pipeline, which was in operation during 1957. A spill associated with this pipeline does not fall within the scope of the Eielson AFB Federal Facility Agreement and, therefore, is not being addressed under this Proposed Plan.

\section{Topic: Risk-Based Cleanup Levels}

Comment \#10: One person wanted to know if the risk-based cleanup levels used to guide the cleanup effort, and to which ADEC agreed, were a special concession to the federal agencies, or if this decision-making process was available for private sites as well.

Response: Eielson AFB signed the Federal Facility Agreement with the ADEC and EPA to conduct cleanup activities under the provisions of the CERCLA as amended by the Superfund Amendments and Reauthorization Act (SARA). These acts include the provision for risk-based cleanup alternatives as appropriate. The state of Alaska environmental regulations provide for alternate cleanup standards where appropriate. This provision is applicable to any site in Alaska, government or private, where the State deems it appropriate under their regulations.

Comment \#11: Groundwater is contained within a single unconfined aquifer at a shallow depth under Eielson AFB. This aquifer has been subjected to contaminants of various source areas resulting in concentrations of contaminants that exceed the federal and State MCLs. In the "Summary of OU2 Source Area Risks," the Plan indicates that groundwater is not used. Is not the source of drinking water at Eielson AFB groundwater from this aquifer? The level of contamination in ST19, ST13, and DP26 exceed MCLs; however, no cleanup of these areas is planned. Yet, the stated cleanup objectives for ST10, SS14, ST13, and DP26 are to reduce groundwater contamination levels below established MCLs, and clean up the soil such that it no longer acts as a contaminant source. Why is this objective not carried throughout Eielson AFB?

Response: The OU2 Baseline Risk Assessment (BLRA) calculated human-health risk for three different land-use scenarios at each site. The current industrial land-use exposure scenario assumed that the current water supply system was used. The future industrial and future residential land-use scenarios both assumed that water is provided by an untreated groundwater well within the site. Thus, the local groundwater contamination was input into two of the three risk calculations. The groundwater at ST19 and ST13 and DP26 both exceed MCLs; however, a cleanup of ST13 and DP26 is planned. 
A cleanup has not been planned for ST19 because soil and groundwater sampling results and the fate and transport modeling both indicate that the contamination at ST19 is restricted to a limited area (approximately 2 acres) directly adjacent to the spill area and that the weathered petroleum contamination in subsurface soils is not expected to act as a significant continuing source of groundwater contamination. Groundwater concentrations in wells located downgradient within 1,000 feet of the spill area do not exceed MCLs. In addition, ST19 is located in a remote area of the base that is not likely to be used for residential purposes in the foreseeable future. Given the low level of residual contamination present and the limited area impacted, no remedial action will be taken at ST19. Institutional controls (e.g., command directives and protective covenants) will be established to prevent the use of groundwater at ST19 and the groundwater will continue to be monitored to verify the results of the fate and transport modeling and to ensure protectiveness of human health and the environment.

Comment \#12: The underlying theme presented in the plan is that "...no significant contamination..." has been determined that warrants further investigation or remediation. No significant contamination implies that contamination is measurable and present at concentrations possibly exceeding State guidelines for soil or State and federal MCLs for water. I understand that the determination of no risk to human health or the environment is based on a health risk assessment and that a detailed health risk analysis was conducted for each of the sites in question to arrive at this conclusion. Does this health risk include the understanding of the groundwater regimen?

Response: The OU2 BLRA was performed after the drafting of the OU2 Remedial Investigation (RI). The RI includes a detailed discussion of the groundwater and this information was included in the BLRA. To be conservative, the BLRA assumed that the source of groundwater in future land-use scenarios was completed where groundwater was most contaminated. No adjustments were made for future dispersion or degradation of groundwater contaminants. In addition, contaminant concentrations were also compared to MCLs to determine the need for remedial action.

Comment \#13: Has the risk assessment included the potential cumulative and synergistic health effects from all these known and potential source areas? How valid of an argument can be made that there are no health risks when known releases of refined petroleum products have occurred on the order of 5,000 gallons but testing has not been performed? In a follow-up telephone call, the commenter indicated that the commenter's concern was that three or four 5,000-gallon spills had been reported with no field sampling completed. What is the potential for unreported releases from these facilities?

Response: The BLRA for the seven OU2 source areas used a conservative approach when addressing the cumulative effect of contaminants on human health. It was assumed that the risk from exposure was cumulative, no matter what the contaminant, even if those present affected different organs or caused different types of cancer.

An abbreviated risk assessment was used for the SER source areas because of the lower probability that these sites would present a significant risk. Detected concentrations were compared to regulatory criteria such as MCLs, ambient water quality criteria, Alaska petroleum cleanup standards for soils, etc. These screening criteria were used in conjunction with other decision criteria to determine the proper course of action for a particular source area.

As suggested in comment \# 10, samples were collected at source areas ST15 and ST16. The only 5,000-gallon spill (SS12) not sampled occurred inside a building. A majority of the spill was contained in the building with approximately 50 gallons estimated as unrecovered. There was no evidence to suggest SS12 ever contained a significant source of contaminants. Therefore, it was concluded that any contaminants present would have 
likely volatilized or infiltrated through subsurface soils to groundwater where they would have been diluted and dispersed.

The reader is referred to comment \# 6 for additional response to this concern.

\section{Topic: Remedial Alternatives Selection}

Public Comment \#14: A local contractor questioned the Soil Venting/Air Sparging/Passive Skimming Alternative (Alternative 4), and recommended the Soil Excavation/Groundwater Treatment Alternative (Alternative 5).

Response: In many areas at Eielson AFB, excavation is not implementable because of base infrastructure. Excavation could collapse building foundations and rupture piping and fuel tanks. Also, because much of the contamination resulted from underground leaks, much of the excavated soil would be clean, but it would have to be removed unnecessarily to access the contaminated subsurface soils close to the water table. However, bioremediation and soil venting can remediate soil contamination in those areas that cannot be excavated (e.g., beneath active tanks and piping). As proposed, a much larger volume of contaminated soils would be remediated with the proposed soil venting and air sparging systems than could be treated by excavation.

Comment \#15: The Proposed Plan indicates that more than 200 years will be required to allow natural degradation of contaminants, yet cleanup can be accomplished in 5 to 10 years, or worst case, 30 years. Justify long-term groundwater monitoring (200 years?) for natural degradation of contaminants and the potential for groundwater flow affecting groundwater uses, compared to implementing corrective action.

I agree that source reduction/elimination, free product recovery, and soil vapor extraction/groundwater air sparging is, at the present time, the most appropriate treatment technology suited to cleanup at Eielson AFB. This technology should be considered for its appropriateness at other known sites where free product is present and/or where soil contamination will be a continuous source of contaminants to the groundwater.

In a follow-up telephone call, the commenter agreed with the proactive approach to remediation; however, the commenter had no way of evaluating the cost effectiveness of the No Action alternative considering the costs of monitoring for 200 years and the impact on groundwater uses.

Response: The no action alternative is required by regulation to be evaluated as a baseline for comparison against other alternatives. However, present worth estimates beyond 30 years become insignificant because of the associated uncertainties and technology development which is very difficult to predict that far out in time. For these reasons, the costs associated with the no action alternative were not estimated.

\section{Topic: Duration of Public Comment Period}

Comment \#16: The plan was received less than 1 week before the public meeting, which is not enough time for an adequate review. The Proposed Plan should be available at least 3 weeks before the public meeting.

Response: Your concern is well founded and will be given consideration for future public meetings. The Proposed Plan for OU2 was provided to the Information Repositories by November 4 and the mailroom by November 5. Because of a long military weekend that delayed the mailing and a holiday on November 11, many people did not receive the Proposed Plan until November 12. The date of the public meeting (November 17 ) was also constrained by the availability of the meeting room and the Thanksgiving holiday on November 25. We will attempt to avoid these problems in the future while 
meeting the scheduling requirements required by regulations. Also, in accordance with the National Contingency Plan, the U.S. Air Force will, upon timely request, extend the public comment by a minimum of 30 additional days to allow adequate time for comment from all interested parties.

\section{Remaining Concerns}

Topic: Storage of contaminated snow and ice.

Comment \#17: A person suggested that a membrane-lined area be developed for storage of snow and ice contaminated with petroleum products, antifreeze, etc. The snow and ice could be stored until the spring melt and the contaminants skimmed or treated and packaged for disposal.

Response: This problem is currently being addressed under the base Hazardous Materials Program. A building is planned for decontamination of equipment. Although the building may not be available for 3 or 4 years, funding is being actively pursued. The building will also have the capability of receiving contaminated snow and ice. Oil-water separation and carbon adsorption equipment will be available for treatment of the melted snow and ice. Some capability for dealing with contaminated snow and ice currently exists at the snow barn. 


\section{DISTRIBUTION}

No. of

Copies

\section{OFFSITE}

12 DOE/Office of Scientific and Technical Information

\section{ONSITE}

19 Pacific Northwest Laboratory

J.S. Fruchter

T.J Gilmore

G.V. Last

R.E. Lewis (5)

T.L. Liikala

P.E. Long

M.T. Murphy

R.M. Smith

P.J. White

Publishing Coordination

Technical Report Files (5)

\section{Routing}

R.M. Ecker

M.J. Graham

P.M. Irving

S.A. Rawson

P.C. Hays (last) 
. 